\title{
Preliminary Results of Preimpoundment Water-Quality Studies in the Tioga River Basin, Pennsylvania and New York
}

\section{U.S. GEOLOGICAL SURVEY}

WATER RESOURCES INVESTIGATIONS

76-66

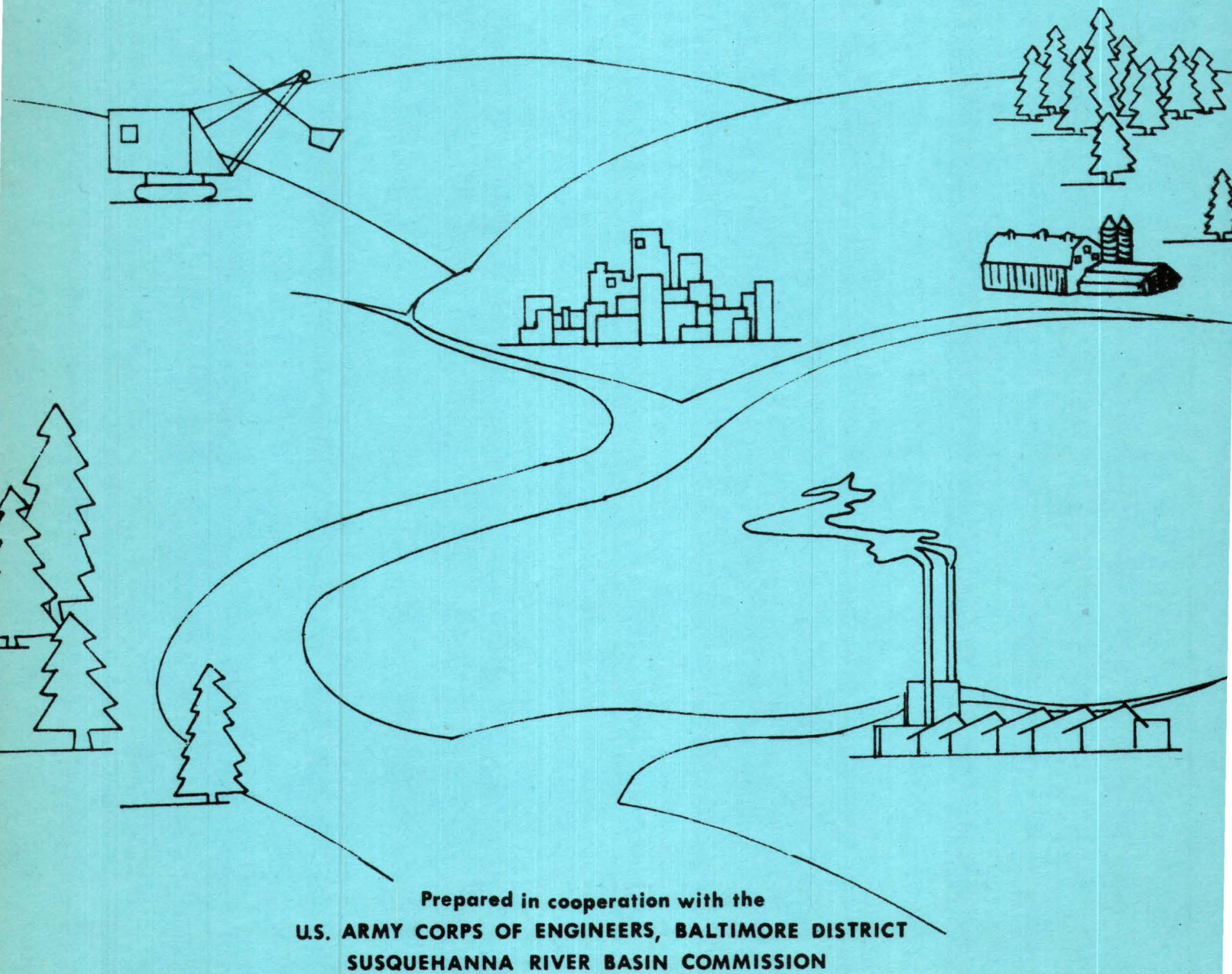




\begin{tabular}{|c|c|c|}
\hline $\begin{array}{l}\text { BIBLIOGRAPHIC DATA } \\
\text { SHEET }\end{array}$ & 1. Report No. & 3. Recipient's Accession No. \\
\hline \multirow{2}{*}{\multicolumn{2}{|c|}{$\begin{array}{l}\text { 4. Title and Subtitle } \\
\text { Preliminary Results of Preimpoundment Water-Quality Studies in } \\
\text { the. Tioga River Basin, Pennsylvania and New York }\end{array}$}} & $\begin{array}{r}\text { 5. Report Date } \\
\text { July } 1976\end{array}$ \\
\hline & & 6. \\
\hline \multicolumn{2}{|c|}{$\begin{array}{l}\text { 7. Author(s) } \\
\text { Janice R. Ward } \\
\text { 9. Performing Organization Name and Address }\end{array}$} & $\begin{array}{l}\text { 8. Performing Organization Rept. } \\
\text { No }{ }_{\text {USGS /WRI } 76-66}\end{array}$ \\
\hline \multirow{2}{*}{\multicolumn{2}{|c|}{$\begin{array}{l}\text { U.S. Geological Survey, Water Resources Division } \\
\text { P. O. Box } 1107 \\
\text { Harrisburg, Pennsylvania } 17108\end{array}$}} & 10. Project/Task/Work Unit No. \\
\hline & & 11. Contract/Grant No. \\
\hline \multicolumn{2}{|c|}{$\begin{array}{l}\text { 12. Sponsoring Organization Name and Address } \\
\text { U.S. Geological Survey, Water Resources Divsiion } \\
\text { P. O. Box } 1107 \\
\text { Harrisburg, Pennsylvania } 17108\end{array}$} & $\begin{array}{l}\text { 13. Type of Report \& Period } \\
\text { Covered Interim } \\
\text { Sept. } 1973 \text { to May } 1975 \\
\text { 14. }\end{array}$ \\
\hline
\end{tabular}

15. Supplementary Notes

Prepared in cooperation with the U.S. Army Corps of Engineers, Baltimore District, and the Susquehanna River Basin Commission.

16. Abstracts The Tioga River and its major tributaries were sampled monthly from September 1973 to May 1975. Water quality in the Tioga River is degraded by acid-mine drainage entering the stream near Blossburg from both strip- and deep-mined areas. The stream supports few species of aquatic life from Blossburg to its confluence with Crooked Creek. Alkaline water of tributaries Mill Creek, Crooked Creek, and the Cowanesque River counteract the acidity carried downstream from Blossburg, and the water-quality of the Tioga River gradually improves, supporting a more diversified population of fish and aquatic life. Relationships between selected water-quality parameters have been developed for the sampling stations throughout the basin. Downstream trends were also examined. The relationships will be further refined and implemented in predictive water-quality models as more data are collected.

17. Key Words and Document Analysis. 17a. Descriptors

Acid mine water, acidity, alkalinity, mine drainage, carbonates, chemical analyses, *preimpoundment, *water quality

17b. Identifiers/Open-Ended Terms

Susquehanna River basin, Pennsylvania, New York

17c. COSATI Field/Group

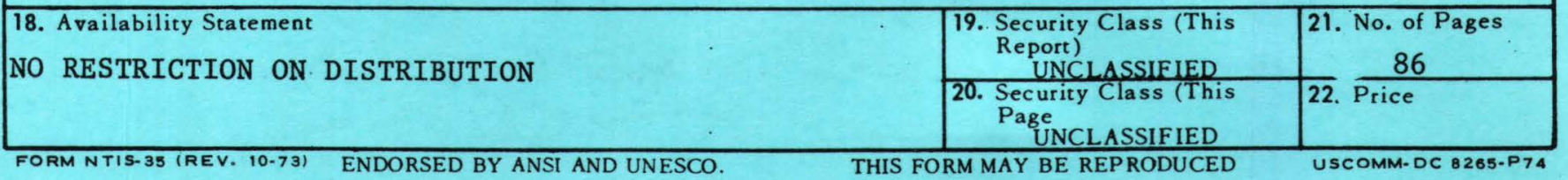




\section{ERRATA SHEET}

Page 22. Sulfate should be $250 \mathrm{mg} / 1$.

Page 26. y axis label should read field alkalinity, in milligrams per litre as $\mathrm{CaCO}_{3}$. 
PRELIMINARY RESULTS OF PREIMPOUNDMENT WATER-QUALITY

STUDIES IN THE TIOGA RIVER BASIN,

PENNSYLVANIA AND NEW YORK

By Janice R. Ward

U.S. GEOLOGICAL SURVEY

Water-Resources Investigations

$76-66$

Prepared in cooperation with

U.S. Army Corps of Engineers

Baltimore District, and the

Susquehanna River Basin Commission 


\section{UNITED STATES DEPARTMENT OF THE INTERIOR \\ Thomas S. Kleppe, Secretary \\ GEOLOGICAL SURVEY \\ V. E. McKelvey, Director}

For additional information write to:

U.S. Geological Survey

Fourth Floor, Federal Building

P. 0. Box 1107

Harrisburg, Pennsylvania 17108 
Factors for converting English Units to International System

(SI) units ....................... . . . v

Abstract . . . . . . . . . . . . . . . . . 1

Introduction ...................... 2

Description of the study area ............... 2

Location and description of impoundments . . . . . . . . . . 4

Location and description of sampling sites . . . . . . . . . 7

Sample collection ................. . . . . 7

Preimpoundment water quality results . . . . . . . . . 12

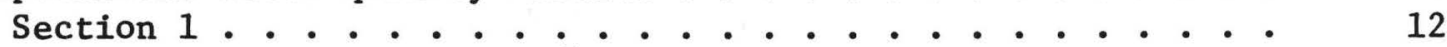

Section 2.......................... 19

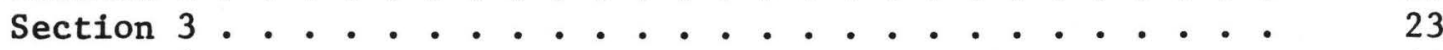

Section 4.......................... 25

Section 5..................... . . . . . 27

Tioga River Profile . . . . . . . . . . . . . 27

Buffer capacity .................. . . . . . 34

Discussion .................... . . . . . 39

Selected references ................. 41

\section{ILLUSTRATIONS}

Figure 1. Map showing Tioga River basin above Lindley, N.Y. . . 3

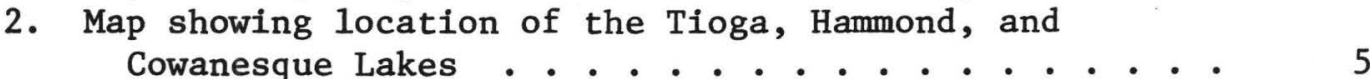

3. Map showing location of sampling sites from

September 1973 to May 1975 . . . . . . . . . 8

4. Graph showing sampling schedule for the Tioga

River basin, September 1973 to May 1975 . . . . . . 10

5. Diagram of Tioga River basin study sections . . . . . 13

6. Map of strip- and deep-mined areas showing major discharge points near Blossburg . . . . . . 16

7-9. Graphs of section 1 showing:

7. Discharge versus laboratory specific conductance . . . . . . . . . . . 18

8. Discharge versus field net alkalinity . . . . 20

9. Field net alkalinity versus field $\mathrm{pH}$...... 21

10-12. Graphs of section 2 showing:

10. Discharge versus laboratory specific conductance . . . . . . . . . . . 24

11. Field net alkalinity versus laboratory specific conductance .......... . . 24

12. Field net alkalinity versus field $\mathrm{pH}$. . . . 25 
Figure 13-14. Graphs showing Cowanesque River:

13. Laboratory specific conductance and field alkalinity profiles ...... 26

14. Chloride and total inorganic nitrogen profiles ................ 28

15-18. Graphs showing Tioga River:

15. Field $\mathrm{pH}$ and laboratory specific conductance profiles ........ 29

16. Field net alkalinity and sulfate profiles ........... 30

17. Total aluminum and total iron profiles ... 31

18. Total manganese and total zinc profiles... 32

19. Graphs of discharge versus total metal concentration for the Tioga River . . . . . . 33

20. Graph of $\mathrm{pH}$ versus - $\log$ concentration showing the relationships of $\mathrm{CO}_{3}{ }^{2-}, \mathrm{HCO}_{3}{ }^{-}, \mathrm{H}_{2} \mathrm{CO}_{3}$, $\mathrm{OH}^{-}$, and $\mathrm{H}^{+}$............... 35

21-22. Graphs of observed versus calculated net alkalinity loads for:

21. Tioga River at Tioga and Tioga River at Tioga Junction...........

22. Tioga River at Lindley . . . . . . . 38

23. Graph of field $\mathrm{pH}$ versus field net alkalinity for Tioga River basin . . . . . . . . .

\section{TABLES}

Table 1. Summary of pertinent physical information for the Tioga, Hammond, and Cowanesque Lakes . . . . 6

2. List of Tioga River basin sampling sites and USGS identification numbers . . . . . . . . . . 9

3. Water-quality analyses for the Tioga River basin . . . 11

4. Maximum, minimum, and median results for selected parameters in the Tioga study area ...... 14-15

5. Minimum standards for drinking water and suggested stream criteria for fish and other aquatic life . . 22

6. Water quality results for the Tioga River basin, September 1973 to May 1975 . . . . . . . 42-79 
FACTORS FOR CONVERTING ENGLISH UNITS TO INTERNATIONAL SYSTEM (SI) UNITS

Multiply English units

Inches (in)

Feet $(f t)$

Miles (mi)

Acres

Square miles $\left(\mathrm{mi}^{2}\right)$

Acre-feet (acre-f $t)$

Cubic feet per second $\left(\mathrm{ft}^{3} / \mathrm{s}\right)$
By

25.40

.3048

1.609

.4047

2.590

$1.233 \times 10^{-3}$

.02832
To obtain (SI) units

Millimetres (mm)

Metres ( $m$ )

Kilometres (km)

Hectare (ha)

Square kilometres $\left(\mathrm{km}^{2}\right)$

Cubic hectometres $\left(\mathrm{hm}^{3}\right)$

Cubic metres per second $\left(\mathrm{m}^{3} / \mathrm{s}\right)$ 



\title{
PRELIMINARY RESULTS OF PREIMPOUNDMENT WATER-QUALITY STUDIES
}

IN THE TIOGA RIVER BASIN, PENNSYLVANIA AND NEW YORK

\section{JANICE R. WARD}

\begin{abstract}
The Tioga River and its major tributaries were sampled monthly from September 1973 to May 1975. Water quality in the Tioga River is degraded by acid-mine drainage entering the stream near Blossburg from both strip- and deep-mined areas. The stream supports few species of aquatic life from Blossburg to its confluence with Crooked Creek. Alkaline water of tributaries Mill Creek, Crooked Creek, and the Cowanesque River counteract the acidity carried downstream from Blossburg, and the water quality of the Tioga River gradually improves, supporting a more diversified population of fish and aquatic life.

All of the streams in the Tioga River basin carry nutrients sufficient for algae blooms. Dissolved solids range from very high to moderately high throughout the basin. The Tioga River has high concentrations of sulfate and heavy metals, particularly iron and manganese. Dissolved oxygen was usually above 80 percent saturation and never dropped below 7.0 milligrams per litre throughout the basin.
\end{abstract}

Relationships between selected water-quality parameters have been developed for the sampling stations throughout the basin. Downstream trends were also examined. The relationships will be further refined and implemented in predictive water-quality models as more data are collected. 


\section{INTRODUCTION}

Three impoundments have been proposed for the Tioga study area by the Baltimore District, U.S. Army Corps of Engineers. They are designed mainly for flood control, but will also provide recreational areas and may improve water quality over that at present downstream from the proposed dams. Two of the reservoirs, Tioga and Hammond Lakes, are presently under construction and will be completed in 1977. Cowanesque Lake is in the planning stages and will be started in the near future.

Since 1973, the U.S. Geological Survey in cooperation with the Corps, has been studying preimpoundment water quality of the Tioga River and its two major tributaries in north-central Pennsylvania in order to provide information useful in the design and operation of the impoundments for optimum waterquality improvement. Hammond Lake will impound alkaline water from Crooked Creek, whereas Tioga Lake will be fed by predominantly acid water from the Tioga River. The acid is a result of mine drainage into tributaries Bear Creek, Coal Creek, and Morris Run, which flow into the Tioga River at Blossburg, $\mathrm{Pa}$. The acid drainage has adversely affected water quality as far as $38 \mathrm{mi}$ (61 $\mathrm{km}$ ) downstream from active or previously strip- and deep-mined areas.

The main purpose of the impoundments is to alleviate future flooding. Major floods occurred in 1865 and 1946, and in June 1972 tropical storm Agnes flooded the Tioga River and its major tributaries, causing millions of dollars of damage. Other expected benefits of the impoundments are improved water quality and enhanced recreational opportunities in Tioga County. This report summarizes results of the first 21 months of this study.

\section{DESCRIPTION OF THE STUDY AREA}

The Tioga study area encompasses a drainage area of $771 \mathrm{mi}^{2}\left(2,000 \mathrm{~km}^{2}\right)$, of which $609 \mathrm{mi}^{2}\left(1,580 \mathrm{~km}^{2}\right)$ lie in Pennsylvania (fig. 1). The Tioga River originates in western Bradford County, $\mathrm{Pa}$., and flows southwestward through Blossburg in Tioga County. From Blossburg the river flows northward for about $25 \mathrm{mi}$ $(40 \mathrm{~km}$ ) to Lindley, N. Y., the downstream limit of the study area. The Tioga River continues north from Lindley and joins the Cohocton River at Painted Post, N. Y., to form the Chemung River, which flows southeast for $45 \mathrm{mi}$ (72 km) to the Susquehanna River.

Steep woodlands and wide valleys characterize the Tioga study area, which lies in the Allegheny Plateau physiographic province. Shale and sandstone dominate the geologic formations, accompanied by coal deposits mined largely in the area just east of Blossburg, $\mathrm{Pa}$. 


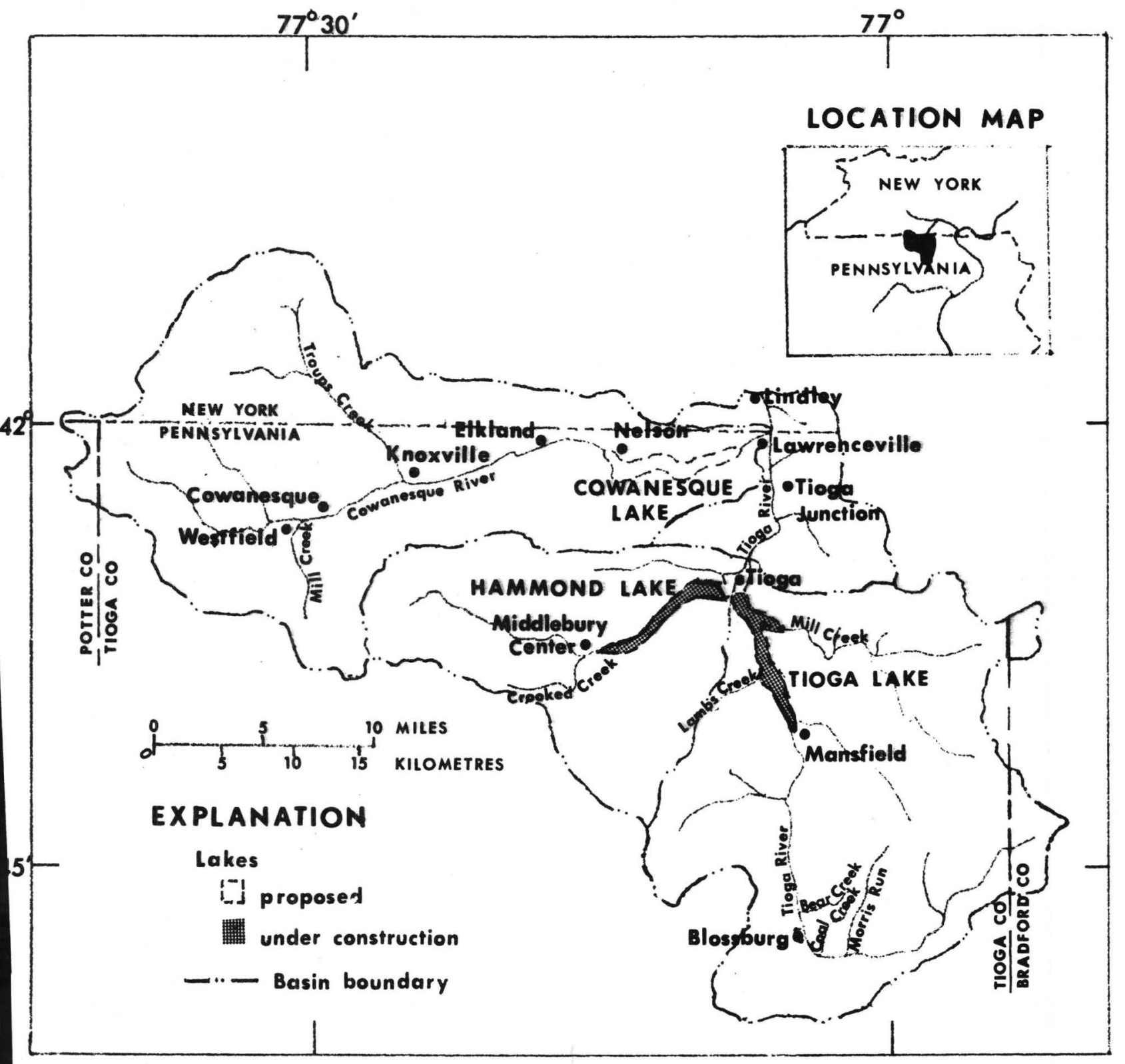

Figure 1.--The Tioga River basin above Lindley. 
The average annual precipitation based on 70 years of record is about 38 in $(965 \mathrm{~mm})$. On the average, 39 percent of the rainfall becomes runoff and 61 percent is evapotranspired. The mean temperature is $48^{\circ} \mathrm{F}\left(9^{\circ} \mathrm{C}\right)$. Lows usually occur in January and February and highs in July and August.

The largest communities in the Tioga study area are the boroughs of Elkland and Westfield in the Cowanesque River basin and Mansfield in the Tioga River basin. The major part of the study area is forested, although a shift has occurred in the past few years from cultivated land to pasture and forest. Dairy and grassland farming are the main agricultural activities in the area.

\section{LOCATION AND DESCRIPTION OF IMPOUNDMENTS}

The Tioga dam (fig. 2) will cross the Tioga River $1.7 \mathrm{mi}(2.7 \mathrm{~km})$ upstream from the confluence with Crooked Creek, and the reservoir at spillway elevation will stretch $9.9 \mathrm{mi}(15.9 \mathrm{~km})$ upstream into Mansfield, Pa. The Hammond dam will be on Crooked Creek $3.3 \mathrm{mi}(5.3 \mathrm{~km})$ upstream from the confluence with the Tioga River, and the reservoir at spillway elevation will extend about $7.8 \mathrm{mi}$ $(12.6 \mathrm{~km}$ ) upstream toward Middlebury Center, $\mathrm{Pa}$. The Cowanesque dam will be on the Cowanesque River $2.2 \mathrm{mi}(3.5 \mathrm{~km})$ upstream from its confluence with the Tioga River and will extend about $8 \mathrm{mi}(12.9 \mathrm{~km})$ upstream at spillway elevation toward Elkland. Some basic information about the planned impoundments is given in table 1.

The Corps of Engineers plans to build a connecting channel between the Tioga and Hammond Lakes to permit water storage in both the Tioga River and Crooked Creek drainage basins, allowing both reservoirs to be operated as one flood control project. The channel will be a weir with a crest elevation at 1,101 ft ms1 (336 m ms1). It will have a gate structure and a tunnel with an invert at 1,058 $\mathrm{ft} \mathrm{ms} 1$ ( $322 \mathrm{~m} \mathrm{~ms}$ ) to allow flow to pass from Tioga Lake to Hammond Lake or vice versa, depending on the elevations of the two lakes.

The main outlet of Tioga-Hammond Lake will be at the Tioga dam. The outlet works are planned for multi-level withdrawal. Under normal conditions, alkaline Crooked Creek water in Hammond Lake will flow through the weir into Tioga Lake and mix with Tioga River water flowing out of the main outlet works of Tioga dam. Normal outflow from Hammond Lake also will be through a 36 in (914 mm) conduit into Crooked Creek.

During extreme floods, water from Tioga Lake will flow through the weir into Hammond Lake and over an ungated spillway into Crooked Creek. Extreme flood flows in Hammond Lake will pass either over the weir into Tioga Lake or over the ungated spillway from Hammond Lake into Crooked Creek.

Outflow from Cowanesque Lake will normally be through a multi-level outlet works into the Cowanesque River. Flood flows will pass over an ungated spillway 


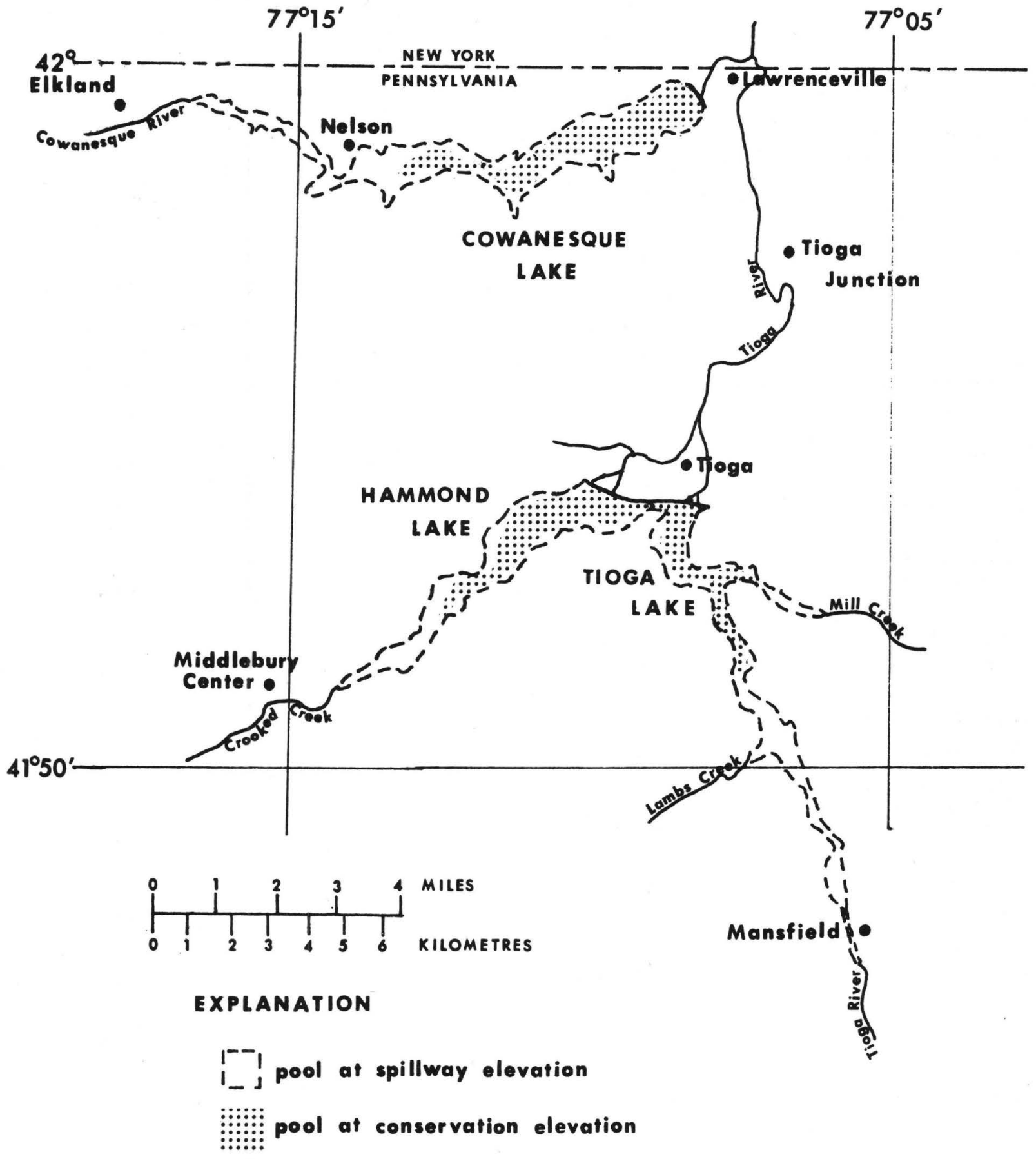

Figure 2.--Location of Tioga, Hommond and Cowanesque Lakes. 
Table 1.--Summary of pertinent physical information for the Tioga, Hammond, and Cowanesque Lakes.

Tioga

Lake

280

480

9,600

50

pool depth (ft)

Spillway elevation

(ft ms1)

1,131

62,000

(acre-ft)

Top elevation

(ft ms1)

1,171
Hammond

Lake

122

298

660

410

8,800

6,975

39

45

1,117

1,131

63,000

89,000

$1,168.5$

1,151 
Beginning in September 1973 water-quality samples were initially collected on a monthly basis for 1 year at 13 sampling sites (fig. 3). After the initial period of data collection, one new site was added and one was moved. A complete list of sampling sites and USGS identification numbers is given in table 2.

Tioga River at Lambs Creek is $6 \mathrm{mi}(9.6 \mathrm{~km})$ downstream from Blossburg. It was the closest sampling site to the acid-mine drainage entering the Tioga River near Blossburg before the station on the Tioga River near Mansfield was added in May 1975. Data for Mill Creek near Tioga permits assessment of the water quality at the mouth of Mill Creek, a major tributary of the Tioga River and of the proposed Tioga Lake. The next site, Tioga River at Tioga is located at the proposed damsite for Tioga Lake.

Crooked Creek at Middlebury Center is at the upstream end of Hammond Lake on Crooked Creek. Both Crooked Creek at Tioga stations are near the damsite of Hammond Lake. Water quality for the Tioga River at Tioga Junction, $1.8 \mathrm{mi}$ (2.9 $\mathrm{km}$ ) downstream from the confluence of the Tioga River and Crooked Creek, reflects the character of water resulting from the mixture of the water of the two streams.

Data from stations on the Cowanesque River at Westfield, Mill Creek at Westfield, and Cowanesque River at Cowanesque indicate the effects of the town of Westfield on the water quality of the Cowanesque River. The station on Troups Creek at Knoxville shows the water quality of that stream, which is a major tributary to the Cowanesque River. The station Cowanesque River at Nelson is near the upstream site of Cowanesque Lake, and data from there are used to evaluate the water quality near the planned inflow of Cowanesque Lake.

The station on the Cowanesque River near Lawrenceville is at the proposed damsite of Cowanesque Lake. Tioga River at Lindley is $1.1 \mathrm{mi}$ (1.8 km) downstream from the junction of the Cowanesque and Tioga Rivers and can be used to evaluate the changes that may occur in the water quality of the Tioga River before and after construction of all three lakes.

\section{SAMPLE COLLECTION}

Sampling during the first year of the study consisted of collecting monthly data at 13 sites (fig. 4). The chemical and physical properties that were measured are grouped into three categories, as shown in table 3. In May 1974 the Geological Survey, in cooperation with the Susquehanna River Basin Commission, began collecting additional samples at the four Tioga River sites for determination of heavy metals. The sites are shown in figure 4, and the metals analyzed are listed in table 3. Sample collection, storage, and analysis followed methods outlined in Brown and others (1974). 


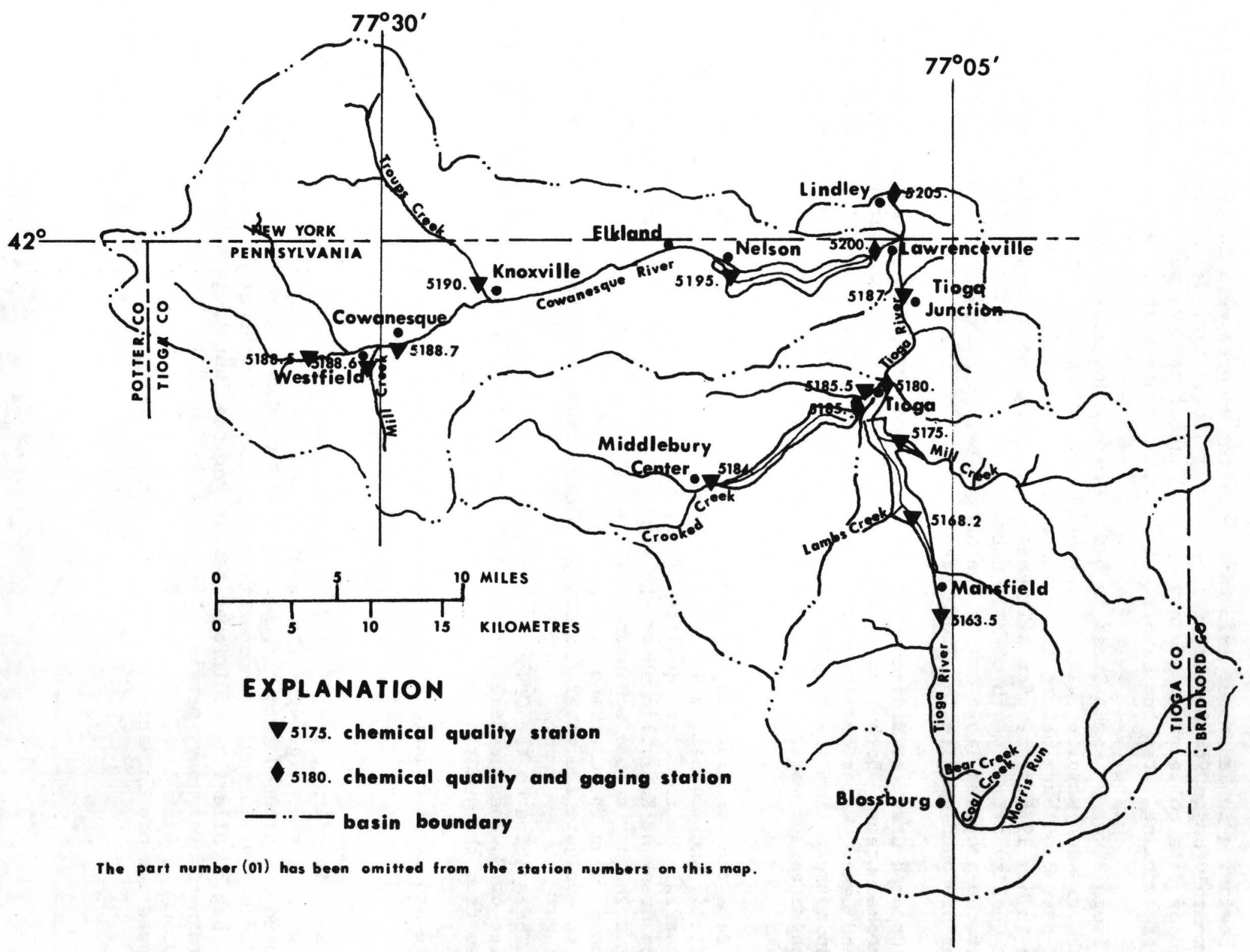

Figure 3.--Location of sampling sites from September 1973 to May 1975. 
Table 2.--List of Tioga River basin sampling sites and USGS identification numbers.

USGS identification number

01516350

01516820

01517500

01518000

01518400

01518500

01518550

01518700

01518850

01518860

01518870

01519000

01519500

01520000

01520500

\section{Station name}

Tioga River near Mansfield

Tioga River at Lambs Creek

Mi11 Creek near Tioga

Tioga River at Tioga

Crooked Creek at Middlebury Center

Crooked Creek at Tioga

Crooked Creek at Tioga

Tioga River at Tioga Junction

Cowanesque River at Westfield

Mill Creek at Westfield

Cowanesque River at Cowanesque

Troups Creek at Knoxville

Cowanesque River at Nelson

Cowanesque River near Lawrenceville

Tioga River at Lindley, N.Y. 


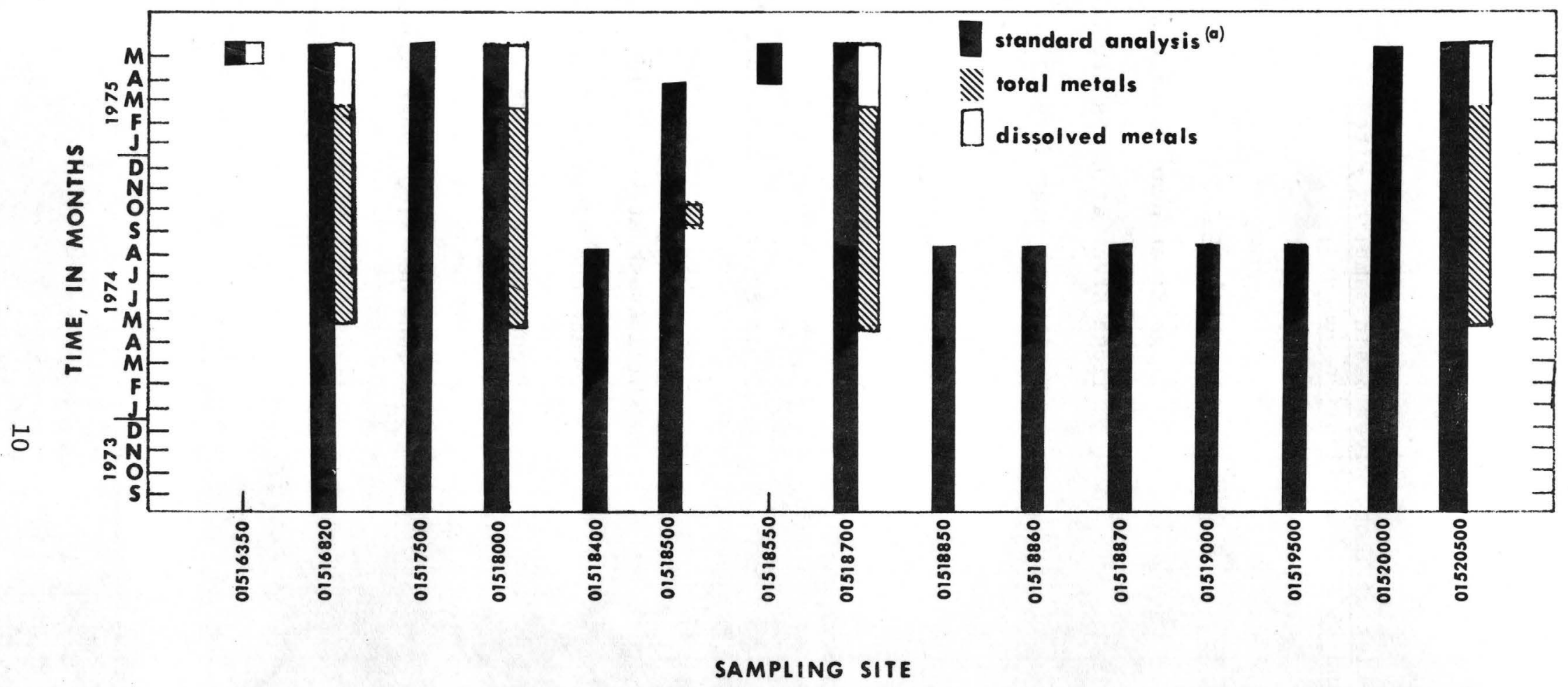

"See table 3 for listing of constituents in each analysis

Figure 4.--Sompling schedule for the Tioga River basin, September 1973 to May 1975. 
Table 3.--Water-quality analyses for the Tioga River basin.

Field Measurements

Laboratory determinations

Discharge (cfs)

$\mathrm{pH}$ (units)

Specific conductance

(micromhos at $25^{\circ} \mathrm{C}$ )

Water temperature $\left({ }^{\circ} \mathrm{C}\right)$

Total alkalinity as $\mathrm{CaCO}_{3}(\mathrm{mg} / 1)$

Total acidity as $\mathrm{CaCO}_{3}$ (mg/1)

$\mapsto \quad$ Dissolved oxygen (mg/1)
Total alkalinity as $\mathrm{CaCO}_{3}$ (mg/1)

Total acidity as $\mathrm{CaCO}_{3}(\mathrm{mg} / 1)$

Specific conductance

(micromhos $/ \mathrm{cm}$ at $25^{\circ} \mathrm{C}$ )

$\mathrm{pH}$ (units)

Sulfate (mg/1)

Chloride (mg/1)

Suspended sediment concentration (mg/1)

Metal Samples $(\mu \mathrm{g} / 1)$

\begin{tabular}{ll} 
& Metal Samples $(\mathrm{g} / 1)$ \\
\cline { 2 - 2 } Aluminum & Iron \\
Arsenic & Lead \\
Cadmium & Manganese \\
Chromium & Mercury \\
Cobalt & Selenium \\
Copper & Silver
\end{tabular}

Zinc
Total nitrate as $\mathrm{N}$ (mg/1)

Tota1 ammonia as $\mathrm{N}$ (mg/1)

Total organic nitrogen as $\mathrm{N}$ (mg/1)

Total Kjedah1 nitrogen as $\mathrm{N}$ (mg/1)

Total phosphorus as $\mathrm{P}$ (mg/1)

Total orthophosphate as $\mathrm{P}(\mathrm{mg} / 1)$ 
After 1 year's basic data had been compiled throughout the Tioga River basin, several changes in the sampling program were adopted for more intensive collection in the area surrounding the planned.Tioga and Hammond Lakes. Sampling beginning in September 1974 continued monthly at only seven of the 13 original sites: Tioga River at Lambs Creek, Mill Creek near Tioga, Tioga River at Tioga, Crooked Creek at Tioga, Tioga River at Tioga Junction, Cowanesque River near Lawrenceville, and Tioga River at Lindley. The constituents sampled remained the same as listed previously.

Starting in March 1975, the total-metal analyses at the four sites on the Tioga River were replaced with determinations of dissolved metals. In April 1975 sampling at Crooked Creek at Tioga was discontinued at the original site and re-established $2.0 \mathrm{mi}(3.2 \mathrm{~km})$ downstream because of construction in the area. In May 1975, a new sampling site was established at Tioga River near Mansfield for the evaluation of water quality above Tioga Lake. Plans for gaging stations at Tioga River near Mansfield, Tioga River at Tioga Junction, and a relocation of the gage now at Cowanesque River at Lawrenceville are underway for fiscal year 1976. Continuous specific conductance, pH, water temperature, and dissolved oxygen will be monitored at Tioga River near Mansfield and Tioga River at Tioga Junction.

\section{PREIMPOUNDMENT WATER QUALITY RESULTS}

The Tioga River basin is broken down into five sections, as shown in figure 5, for ease of discussion. Section 1 includes the Tioga River from headwaters to confluence with Crooked Creek. Section 2 includes the entire Crooked Creek River basin. Section 3 includes the Tioga River below the Crooked Creek confluence to the Cowanesque River, and section 4 includes the whole Cowanesque River basin. The Tioga River below its confluence with the Cowanesque River to Lindley, N. Y., constitutes section 5 and completes the study area. Table 4 summarizes the results of water-quality sampling in each study section. Dissolved oxygen was not included in the table because it was nearly always above 80 percent saturation at all sampling sites during the study. The complete tabulation of the results of water-quality sampling from September 1973 to May 1975 is listed in table 6.

\section{Section 1}

Almost all of the acid mine drainage that affects the Tioga River is contributed by three small tributaries near Blossburg: Morris Run, Coal Creek and Bear Creek (fig. 6). The area around the village of Morris Run has been extensively deep- and strip-mined. The deep mines are drift mines, which allow water to flow by gravity through and out of the mines, thus eliminating the necessity of pumping. There is presently no active deep mining in the area, and rainfall percolates into and flows through the abandoned deep mines, producing acid mine water that discharges at several places in the basin, into the three acid tributaries, and then into the Tioga River. 


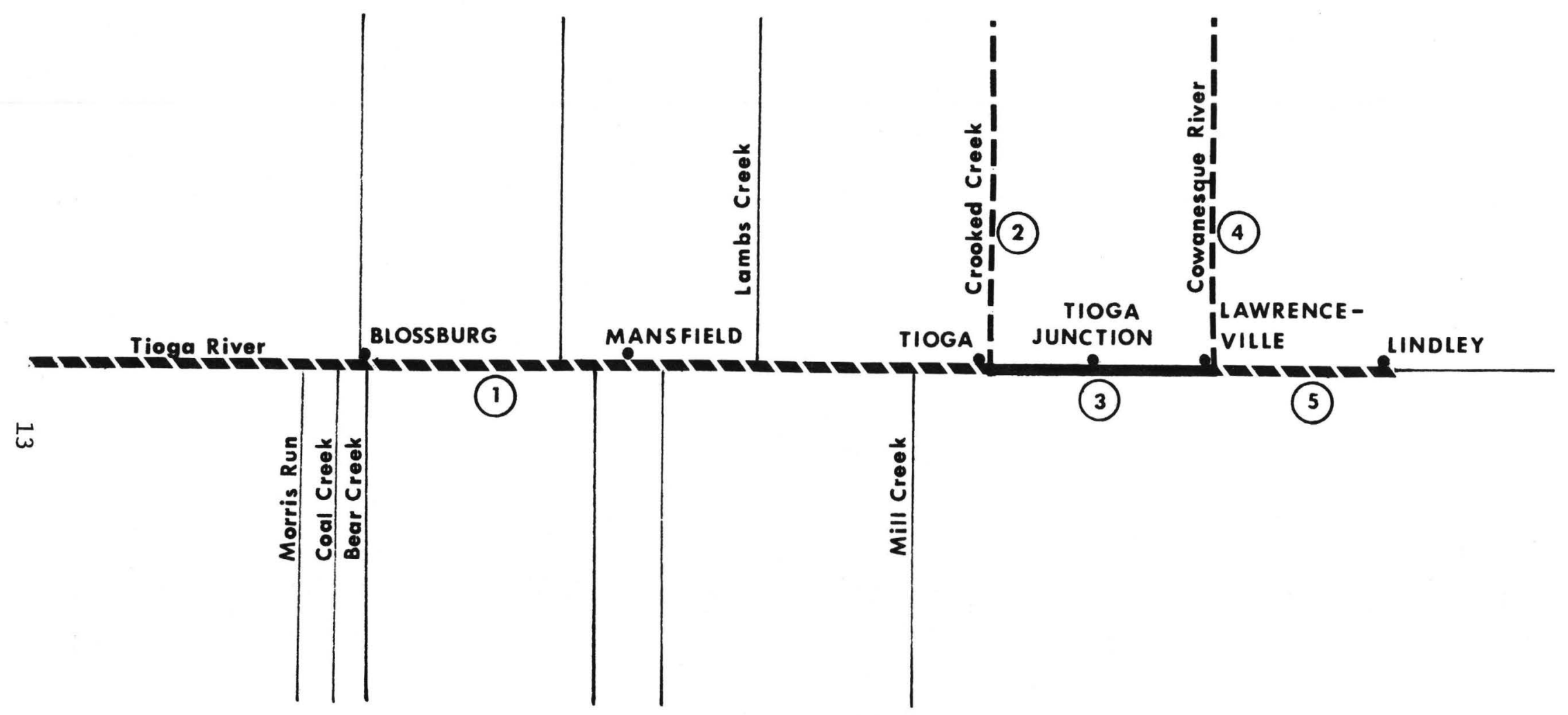

Figure 5.--Tioga River basin study sections. 
Table 4.--Maximum, minimum and median results for selected parameters in the Tioga study area.

\begin{tabular}{|c|c|c|c|c|c|c|c|c|c|c|c|c|c|c|}
\hline $\begin{array}{l}\text { Station } \\
\text { name }\end{array}$ & 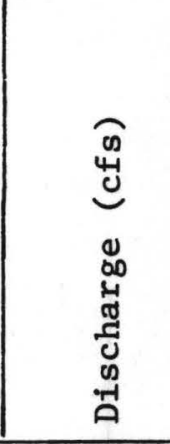 & 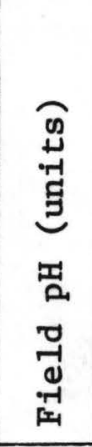 & 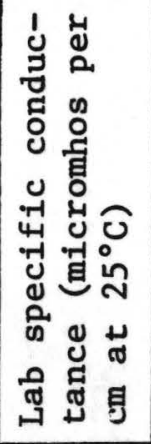 & 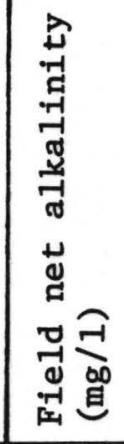 & 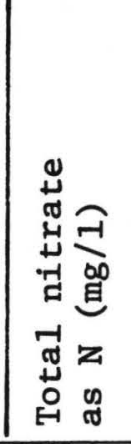 & 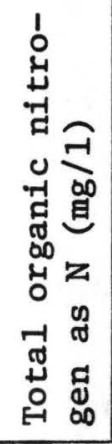 & 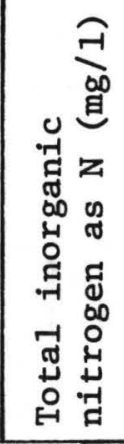 & 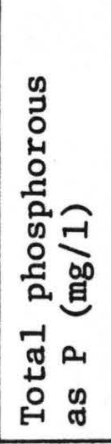 & 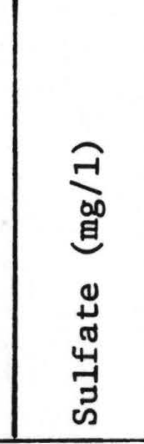 & 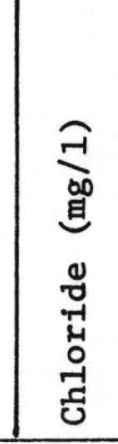 & 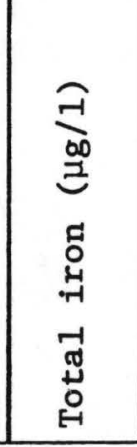 & 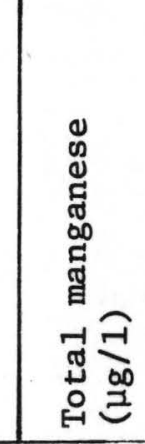 & 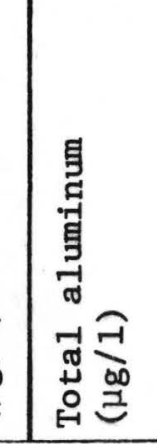 & 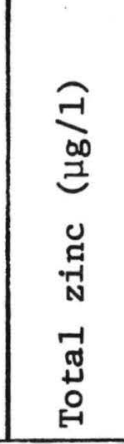 \\
\hline $\begin{array}{l}01516820 \\
\text { Tioga River at } \\
\text { Lambs Creek }\end{array}$ & $\begin{array}{r}1,500 \\
29 \\
190\end{array}$ & $\begin{array}{l}6.6 \\
3.4 \\
4.4\end{array}$ & $\begin{array}{l}587 \\
109 \\
223\end{array}$ & $\begin{array}{r}-1 \\
-160 \\
-51\end{array}$ & $\begin{array}{l}.60 \\
.23 \\
.57\end{array}$ & $\begin{array}{l}.56 \\
.08 \\
.20\end{array}$ & $\begin{array}{r}2.01 \\
.28 \\
.73\end{array}$ & $\begin{array}{l}.29 \\
.02 \\
.04\end{array}$ & $\begin{array}{r}256 \\
25 \\
84\end{array}$ & $\begin{array}{r}10.0 \\
2.5 \\
5.6\end{array}$ & $\begin{array}{r}3,400 \\
500 \\
1,550\end{array}$ & $\begin{array}{r}8,400 \\
610 \\
2,900\end{array}$ & $\begin{array}{r}12,000 \\
20 \\
2,900\end{array}$ & $\begin{array}{r}1,300 \\
90 \\
490\end{array}$ \\
\hline $\begin{array}{l}01517500 \\
\text { Mi11 Creek } \\
\text { near Tioga }\end{array}$ & $\begin{array}{l}473 \\
6.3 \\
76\end{array}$ & $\begin{array}{l}8.9 \\
6.3 \\
8.1\end{array}$ & $\begin{array}{l}214 \\
109 \\
137\end{array}$ & $\begin{array}{l}69 \\
11 \\
39\end{array}$ & $\begin{array}{r}1.10 \\
.02 \\
.45\end{array}$ & $\begin{array}{l}.35 \\
.13 \\
.24\end{array}$ & $\begin{array}{r}1.17 \\
.09 \\
.50\end{array}$ & $\begin{array}{l}.08 \\
.01 \\
.02\end{array}$ & $\begin{array}{r}1.10 \\
.02 \\
.45\end{array}$ & $\begin{array}{r}10.0 \\
2.5 \\
6.0\end{array}$ & --- & --- & --- & ---- \\
\hline $\begin{array}{l}01518000 \\
\text { Tioga River } \\
\text { at Tioga }\end{array}$ & $\begin{array}{r}1,880 \\
30 \\
255\end{array}$ & $\begin{array}{l}6.9 \\
4.3 \\
5.6\end{array}$ & $\begin{array}{l}413 \\
105 \\
192\end{array}$ & $\begin{array}{r}22 \\
-69 \\
-6\end{array}$ & $\begin{array}{l}.93 \\
.16 \\
.59\end{array}$ & $\begin{array}{l}.69 \\
.06 \\
.18\end{array}$ & $\begin{array}{l}.95 \\
.19 \\
.69\end{array}$ & $\begin{array}{l}.15 \\
.01 \\
.03\end{array}$ & $\begin{array}{r}188 \\
27 \\
64\end{array}$ & $\begin{array}{r}11.0 \\
2.1 \\
6.0\end{array}$ & $\begin{array}{r}2,600 \\
150 \\
780\end{array}$ & $\begin{array}{r}5,900 \\
450 \\
2,000\end{array}$ & $\begin{array}{r}7,400 \\
10 \\
2,350\end{array}$ & $\begin{array}{r}3,100 \\
60 \\
255\end{array}$ \\
\hline $\begin{array}{l}01518400 \\
\text { Crooked Creek at } \\
\text { Middlebury Center }\end{array}$ & $\begin{array}{c}453 \\
3.3 \\
39\end{array}$ & $\begin{array}{l}8.9 \\
6.2 \\
7.2\end{array}$ & $\begin{array}{r}225 \\
93 \\
172\end{array}$ & $\begin{array}{r}a / 73 \\
18 \\
53\end{array}$ & $\begin{array}{r}1.20 \\
.11 \\
.39\end{array}$ & $\begin{array}{r}.50 \\
.12 \\
.21\end{array}$ & $\begin{array}{r}1.27 \\
.19 \\
.43\end{array}$ & $\begin{array}{l}.36 \\
.01 \\
.03\end{array}$ & $\begin{array}{l}24 \\
14 \\
18\end{array}$ & $\begin{array}{r}12.0 \\
2.5 \\
7.4\end{array}$ & -- & -- & --- & $-\infty$ \\
\hline $\begin{array}{l}01518500 \\
\text { Crooked Creek } \\
\text { at Tioga }\end{array}$ & $\begin{array}{l}811 \\
10.1 \\
66\end{array}$ & $\begin{array}{l}8.2 \\
6.4 \\
7.3\end{array}$ & $\begin{array}{l}221 \\
111 \\
146\end{array}$ & $\begin{array}{l}79 \\
23 \\
37\end{array}$ & $\begin{array}{l}.88 \\
.02 \\
.50\end{array}$ & $\begin{array}{l}.66 \\
.16 \\
.29\end{array}$ & $\begin{array}{r}1.28 \\
.11 \\
.57\end{array}$ & $\begin{array}{l}.61 \\
.01 \\
.07\end{array}$ & $\begin{array}{l}28 \\
15 \\
19\end{array}$ & $\begin{array}{r}10.0 \\
3.5 \\
5.8\end{array}$ & - & --- & --- & -- \\
\hline
\end{tabular}




\begin{tabular}{|c|c|c|c|c|c|c|c|c|c|c|c|c|c|c|}
\hline 01518700 & 2,900 & 7.8 & 329 & 31 & 1.50 & 1.30 & 1.64 & .49 & 123 & 10.0 & 4,500 & 5,700 & 2,600 & 580 \\
\hline Tioga River & 45 & 5.6 & 108 & -2 & .16 & .05 & .25 & .01 & 25 & 2.1 & 20 & 470 & 0 & 60 \\
\hline at Tioga & 460 & 6.9 & 171 & 8 & .45 & .23 & .64 & .05 & 51 & 6.0 & 715 & 1,250 & 1,230 & 125 \\
\hline
\end{tabular}

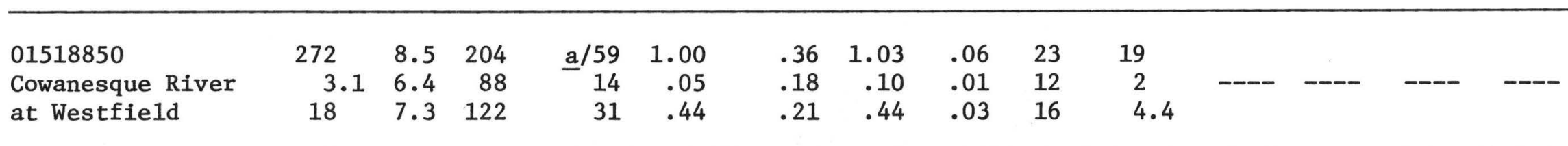

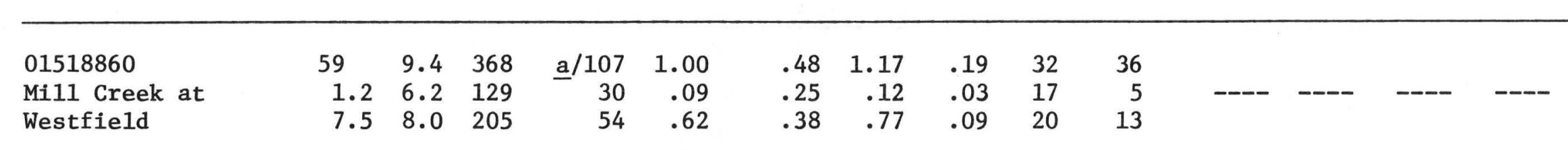

\begin{tabular}{lrrrrrrrrrrrr}
\hline 01518870 & 540 & 8.7 & 572 & a/110 & 1.00 & .81 & 1.32 & .14 & 54 & 93 \\
Cowanesque River & 7.6 & 6.4 & 114 & 22 & .10 & .19 & .13 & .01 & 17 & 4 \\
at Cowanesque & 33 & 8.0 & 220 & 45 & .48 & .47 & .66 & .04 & 24 & 24
\end{tabular}

$\begin{array}{lrrrrrrrrrrrr} & & & & & & & \\ 01519000 & 312 & 8.8 & 239 & \text { a } / 97 & 1.80 & .68 & 1.90 & .11 & 30 & 12 \\ \text { Troups Creek } & 2.6 & 6.1 & 124 & 27 & .20 & .19 & .25 & .01 & 16 & 4 \\ \text { at Knoxvi11e } & 14.5 & 8.0 & 205 & 63 & .78 & .30 & .62 & .01 & 21 & 7.5\end{array}$

\begin{tabular}{|c|c|c|c|c|c|c|c|c|c|c|c|c|c|c|}
\hline $\begin{array}{l}01519500 \\
\text { Cowanesque River } \\
\text { at Nelson }\end{array}$ & $\begin{array}{r}1,430 \\
17 \\
93\end{array}$ & $\begin{array}{l}9.3 \\
6.4 \\
7.8\end{array}$ & $\begin{array}{l}364 \\
133 \\
222\end{array}$ & $\begin{array}{r}\text { a/ } 88 \\
28 \\
58\end{array}$ & $\begin{array}{r}1.90 \\
.02 \\
.60\end{array}$ & $\begin{array}{l}.63 \\
.20 \\
.41\end{array}$ & $\begin{array}{r}2.07 \\
.10 \\
.65\end{array}$ & $\begin{array}{l}.10 \\
.02 \\
.04\end{array}$ & $\begin{array}{l}38 \\
19 \\
25\end{array}$ & $\begin{array}{l}47 \\
5 \cdot 5 \\
15\end{array}$ & ---- & ---- & ---- & ---- \\
\hline $\begin{array}{l}01520000 \\
\text { Cowanesque River } \\
\text { near Lawrenceville }\end{array}$ & $\begin{array}{r}1,400 \\
17 \\
175\end{array}$ & $\begin{array}{l}9.1 \\
6.3 \\
7.8\end{array}$ & $\begin{array}{l}352 \\
124 \\
189\end{array}$ & $\begin{array}{l}90 \\
24 \\
48\end{array}$ & $\begin{array}{r}1.20 \\
.05 \\
.54\end{array}$ & $\begin{array}{l}.56 \\
.16 \\
.30\end{array}$ & $\begin{array}{r}1.24 \\
.06 \\
.66\end{array}$ & $\begin{array}{l}.20 \\
.01 \\
.04\end{array}$ & $\begin{array}{l}35 \\
20 \\
25\end{array}$ & $\begin{array}{r}39 \\
5 \\
14\end{array}$ & ---- & ---- & ---- & ---- \\
\hline $\begin{array}{l}01520500 \\
\text { Tioga River } \\
\text { at Lindley }\end{array}$ & $\begin{array}{r}3,280 \\
62 \\
545\end{array}$ & $\begin{array}{l}7.7 \\
6.2 \\
7.1\end{array}$ & $\begin{array}{l}342 \\
118 \\
177\end{array}$ & $\begin{array}{l}41 \\
15 \\
27\end{array}$ & $\begin{array}{r}1.20 \\
.08 \\
.50\end{array}$ & $\begin{array}{l}.21 \\
.01 \\
.09\end{array}$ & $\begin{array}{r}1.23 \\
.12 \\
.71\end{array}$ & $\begin{array}{l}.09 \\
.01 \\
.03\end{array}$ & $\begin{array}{l}93 \\
23 \\
44\end{array}$ & $\begin{array}{l}20 \\
4 \\
8.5\end{array}$ & $\begin{array}{r}1,200 \\
0 \\
330\end{array}$ & $\begin{array}{r}2,300 \\
360 \\
870\end{array}$ & $\begin{array}{r}920 \\
0 \\
350\end{array}$ & $\begin{array}{r}310 \\
50 \\
105\end{array}$ \\
\hline
\end{tabular}

a/ Total alkalinity as $\mathrm{CaCO}_{3}$ only available for this station. 


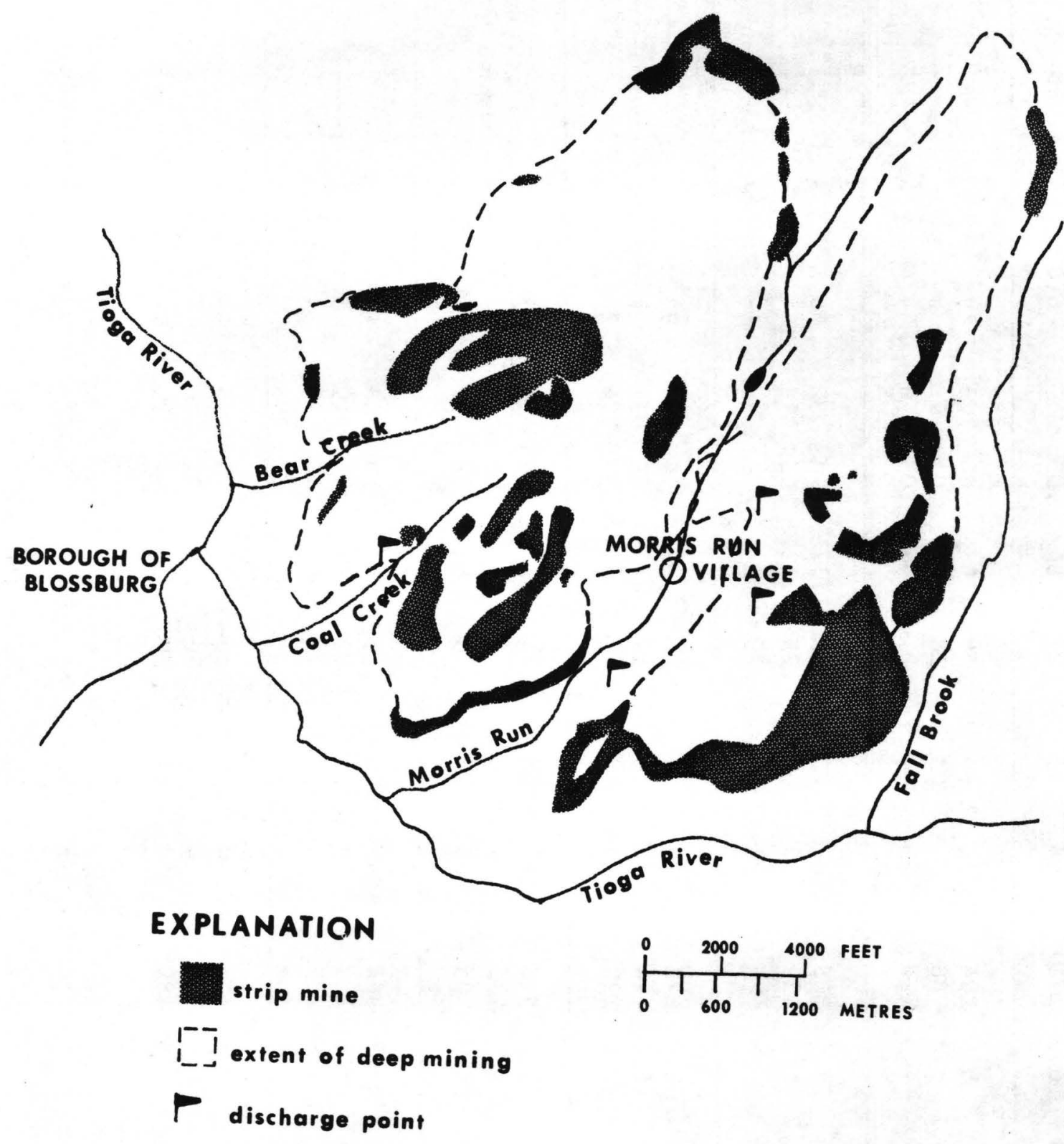

Figure 6.--Strip- and deep-mined areas showing major discharge points near Blossburg. 
Acid mine drainage is produced by the oxidation of iron sulfide materials through contact with water and air, and it is possibly catalyzed by different species of iron bacteria. Ferrous sulfate and sulfuric acid are two major products of the oxidation of pyrite $\left(\mathrm{FeS}_{2}\right)$, a mineral commonly found in coal mines. Ferrous sulfate, in the presence of oxygen, oxidizes to form ferric sulfate, which then hydrolyzes to form insoluble ferric hydroxide and more sulfuric acid.

$$
\begin{gathered}
2 \mathrm{FeS}_{2}+7 \mathrm{O}_{2}+2 \mathrm{H}_{2} \mathrm{O} \rightleftharpoons 2 \mathrm{FeSO}_{4}+2 \mathrm{H}_{2} \mathrm{SO}_{4} \\
4 \mathrm{FeSO}_{4}+2 \mathrm{H}_{2} \mathrm{SO}_{4}+\mathrm{O}_{2} \rightleftharpoons 2 \mathrm{Fe}_{2}\left(\mathrm{SO}_{4}\right)_{3}+2 \mathrm{H}_{2} \mathrm{O} \\
\mathrm{Fe}_{2}\left(\mathrm{SO}_{4}\right)_{3}+6 \mathrm{H}_{2} \mathrm{O} \rightleftharpoons 2 \mathrm{Fe}(\mathrm{OH})_{3}+3 \mathrm{H}_{2} \mathrm{SO}_{4} \\
6
\end{gathered}
$$$$
\begin{aligned}
11 \times 32= & 352 \mathrm{~ms} / \mathrm{L} \\
& \rightarrow 564 \mathrm{~m} / \mathrm{L}
\end{aligned}
$$

The oxidation of pyrite contributes large quantities of iron, acid, and sulfate to the receiving waters. As a result, the $\mathrm{pH}$ of the water is very low, of ten below $\mathrm{pH} 3$, and many other metals besides iron are dissolved by the acidic water. As the water flows away from the source of contamination, it becomes more alkaline by dilution and reaction with contributions from tributaries and runoff. The iron begins to precipitate as the $\mathrm{pH}$ increases, forming a yellow-orange precipitate $\mathrm{Fe}(\mathrm{OH})_{3}$, commonly known as yellow-boy, on the stream bottom. Other metals will also precipitate as their solubilities decrease with increasing $\mathrm{pH}$, and the stream bottom becomes coated with precipitates.

$$
\mathrm{H}_{2} \mathrm{SO} 4+\mathrm{FeS} \rightarrow \mathrm{FeSO}_{4}+\mathrm{H}_{2} \mathrm{~S}
$$

Waters severely affected by acid mine drainage cannot support diversified aquatic life. Warm water fish cannot tolerate a pH below 5.5 and cannot reproduce in waters below $\mathrm{pH}$ 6.5. Cold-water species may tolerate a $\mathrm{pH}$ as low as 5.0 but cannot reproduce in waters below $\mathrm{pH} 6.0$. At low pHs, little diversity is found in species of microorganisms, algae, and plants. With such a limited environment of aquatic life, recreational assets of acidic streams are restricted.

of the four stations included in section 1, on1y Mill Creek near Tioga is not on the Tioga River. Water from Mill Creek, being less mineralized than that of the Tioga River, decreases the specific conductance found upstream at Tioga River at Lambs Creek by about 50 percent at low flow, 20 percent during median flow, and increases the conductance by as much as 10 percent at high flow over the range of flows sampled during the study period (fig. 7). For example, at a discharge of $200 \mathrm{ft}^{3} / \mathrm{s}\left(5.7 \mathrm{~m}^{3} / \mathrm{s}\right)$ at Tioga River at Tioga, the specific conductance of the water is about 150 micromhos. The corresponding specific conductance at Tioga River at Lambs Creek is about 220 micromhos, a decrease of 32 percent. 


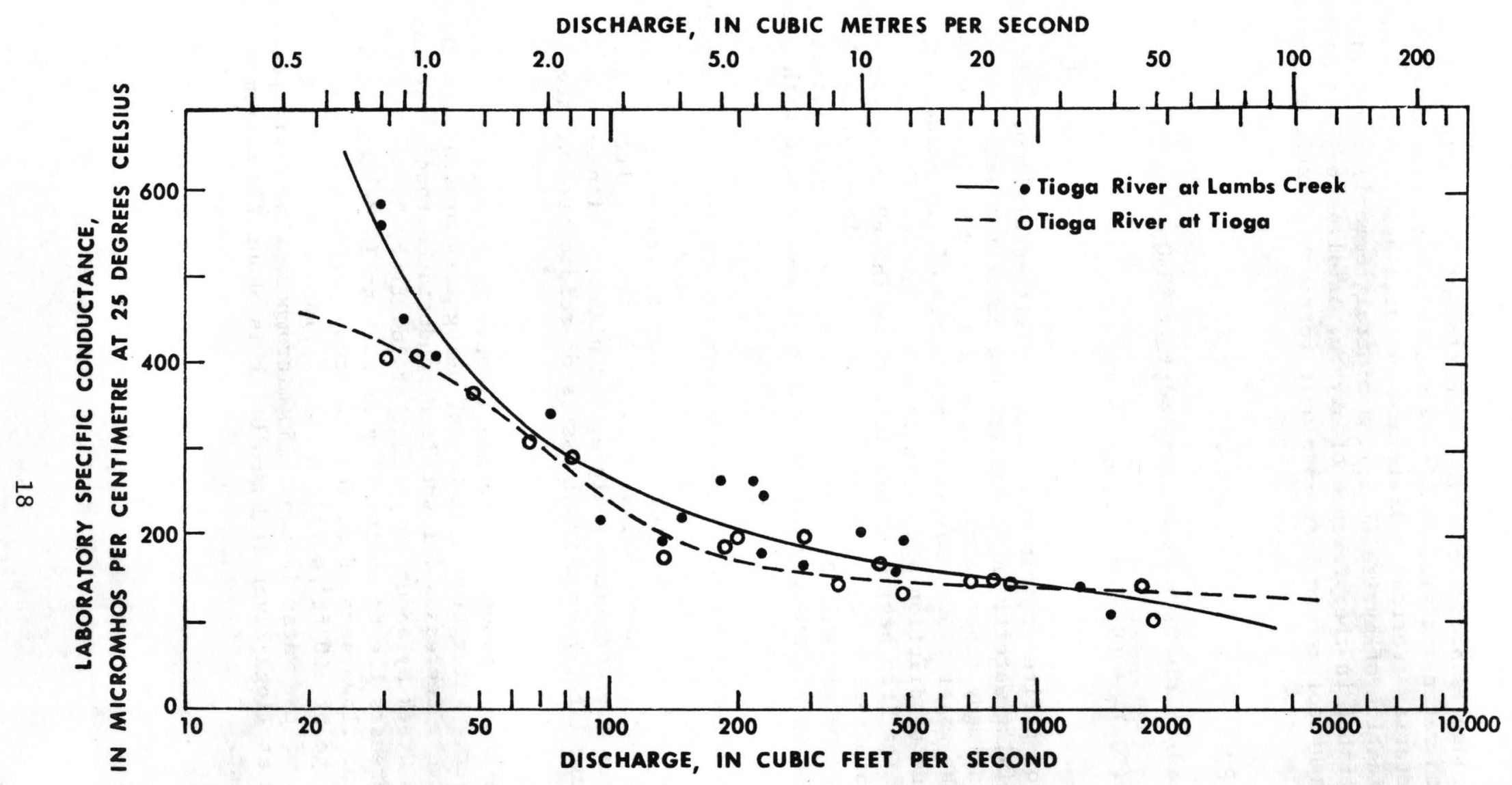

Figure 7.--Discharge versus Zaboratory specific conductance for two stations in section 1. 
Figure 8 shows that net alkalinity $1 /$ also increases between Tioga River at Lambs Creek and Tioga River at Tioga because Mill Creek has about the same buffering capacityl/ as Crooked Creek, but Mill Creek, because its discharge is only about 60 percent of that of Crooked Creek, does not enhance the water quality of the Tioga River as significantly as Crooked Creek does. Figure 9 illustrates that the relationship between $\mathrm{pH}$ and net alkalinity of the Tioga River is about the same at both Lambs Creek and Tioga.

The extent and degree of beneficial effects of Mill Creek on the impounded Tioga River water, when Tioga Lake is completed, will depend upon the mixing and stratification in the lake.

The station Tioga River near Mansfield was not included in the above discussion because only one sample was collected during the period covered in this report. Interpretation of water quality at this station will be included in the final report, although it is assumed here that the water should be of slightly lower quality than that at Tioga River at Lambs Creek because the Mansfield station is closer to the acid mine drainage.

Acidity is not the only problem associated with acid mine drainage. High sulfate and heavy metals concentrations are found throughout study section 1 , with the exception of Mill Creek (table 4). Total iron and total manganese exceeded the U.S. Public Health Service (1962) maximum limits for drinking water at all of the sites on the Tioga River. The limits for selected parameters for drinking water are given in table 5. Sulfate, total iron, total manganese, total aluminum, and total zinc varied proportionately with discharge at all of the Tioga River sites. A discussion of the metals will be deferred until later in this report, where the entire Tioga River basin is discussed as a single unit.

The concentrations of inorganic nitrogen and total phosphorus in Section 1 are well above the minimum concentrations necessary to produce algae blooms in lakes. Sawyer and others (1947) found that a minimum of $0.30 \mathrm{mg} / 1$ of inorganic nitrogen as $\mathrm{N}$ and $0.01 \mathrm{mg} / 1$ of phosphorus as $\mathrm{P}$ could cause algae blooms. Even though heavy blooms have not been observed in the Tioga River, the nutrient load could cause nuisance blooms in Tioga Lake.

\section{Section 2}

As shown in table 4, Crooked Creek is an alkaline, moderately well buffered stream containing no excessive amounts of sulfate, chloride, or dissolved solids. As in section 1, nutrients in Crooked Creek are abundant enough to produce algae blooms if a favorable environment exists in Hammond Lake.

1/ Definition is found in section on buffer capacity, pp. 34-39. 


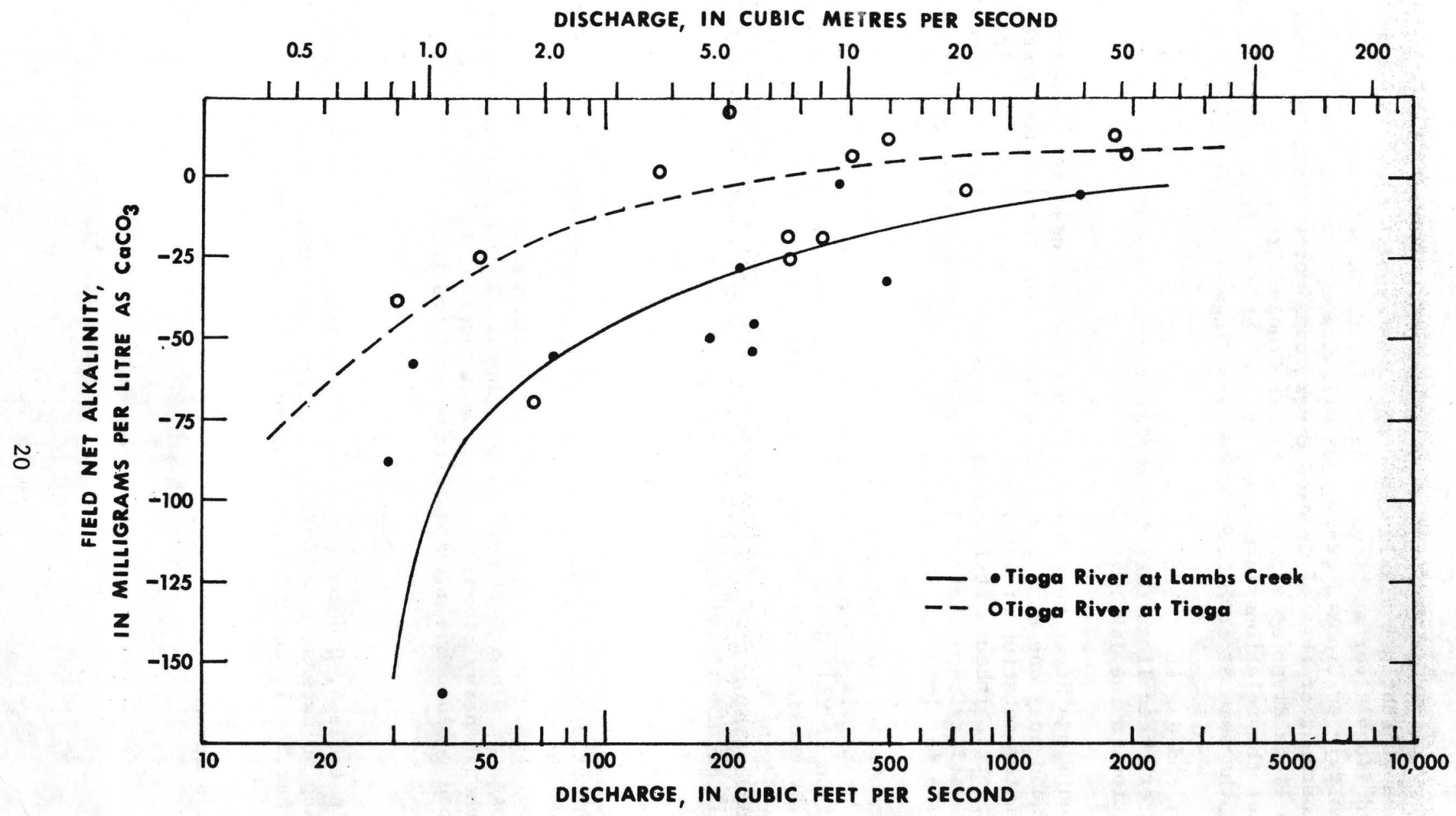

Figure 8.--Discharge versus field net alkalinity for two stations in section 1. 


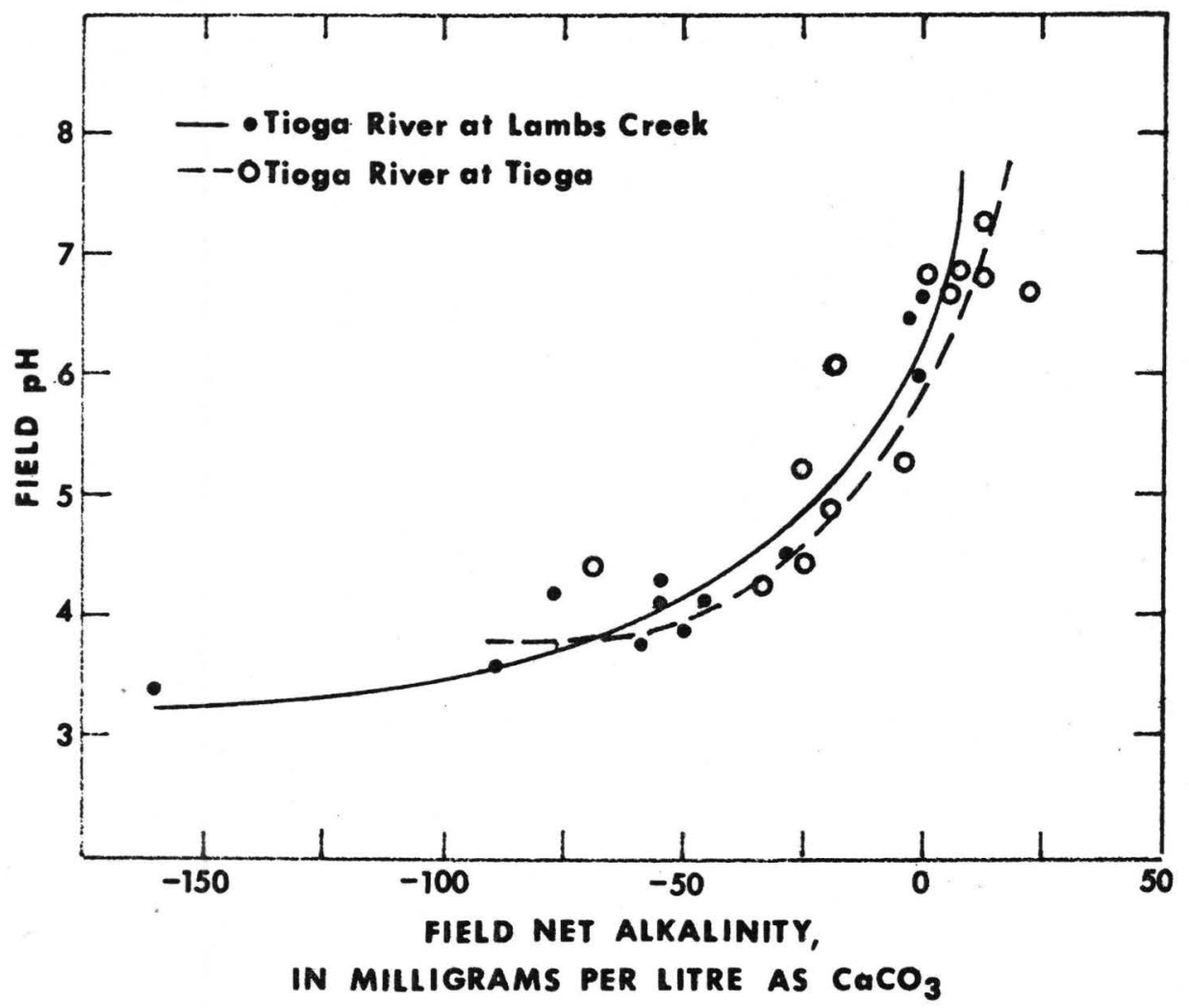

Figure 9.--Field net alkalinity versus field $p H$ for two stations in section 1. 
Table 5.--Minimum standards for drinking water and suggested stream criteria for fish and other aquatic life.

[Taken from Moran and Wentz, 1974]

(Results in milligrams per litre, except as noted)

Substnace

Drinking water

standards

$\underline{a} / 0.05(0.01) \underline{b} /$

1.0

Arsenic

a $/ 1.0$

Barium

Cadmium

Chloride

Chromium

Cobalt

Copper

Cyanide

Iron

Lead

Manganese

Mercury

Nicke1

Nitrate as $\mathrm{N}$

Selenium

Silver

Sulfate

Zinc

pH (units) a/ .01

250

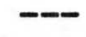

.05

.50

$\underline{b} / 1.0$

$.01-.02$

a / .20 (.01) b /

b/ :30

.30

a/ .05

b/ .05

a/ .005

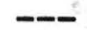

10.2

a/ .01

1.0

a/ .05

.0001

.250

b/ 5.0

$.03-.07$

$6 \leq \mathrm{pH} \leq 9$

$6.5 \leq \mathrm{pH} \leq 8.5$

a/ Maximum permissible concentration.

bi Recommended limit. 
One total-metals sample was collected at Crooked Creek at Tioga on October 10, 1973. Of the metals sampled, manganese $(130 \mathrm{ug} / 1)$ and iron $(1,300$ ug/1) exceeded the U.S. Public Health Service (1962) drinking water standards.

Figures 10-12 illustrate the relationships found between discharge, laboratory specific conductance, field net alkalinity, and field $\mathrm{pH}$ at the two stations in the Crooked Creek basin.// Crooked Creek at Middlebury Center is representative of the inflow to Hammond Lake. Crooked Creek at Tioga illustrates the present water quality at the Hammond Lake damsite. After the lake has been constructed, the water quality at the damsite and the outflow from Hammond Lake will probably differ from that found at Crooked Creek at Tioga because of the influence of the impoundment, but measurement of the inflow and proposed damsite does give an indication of the water-quality changes which occur because of small tributary and rainfall contributions to the stream between the two sites.

Both figures 10 and 11 show that there is a good relationship between the parameters graphed. Figure 12 illustrates a general trend between $\mathrm{pH}$ and net alkalinity, but any predictions of net alkalinity from a measured $\mathrm{pH}$ and vice versa would result in gross errors. The relation between $\mathrm{pH}$ and net alkalinity holds throughout the study area, though some sites show more scatter than others.

\section{$\underline{\text { Section } 3}$}

All of the acid mine drainage parameters apparent in section 1 are moderated by the effects of Crooked Creek in section 3, as measured at Tioga River at Tioga Junction. Heavy metals, sulfates, and nutrients are still excessively high, but a median $\mathrm{pH}$ of 5.6 permits more abundant aquatic life than found anywhere in the Tioga River from Blossburg to Tioga.

Specific conductance, $\mathrm{pH}$, net alkalinity, and discharge varied similarly to that found at Tioga River at Tioga. Because Tioga and Hammond Lakes will be joined with water flowing between the two reservoirs, information defining the mixing capabilities of Tioga River and Crooked Creek water would be helpful in predicting future water quality of both the reservoirs and the Tioga River downstream from the two impoundments. A section concerning buffer capacity and the prediction of both net alkalinity and $\mathrm{pH}$ of mixtures of these waters is included later in this report.

2/ When field net alkalinity values were unavailable, total field alkalinity values were substituted. 


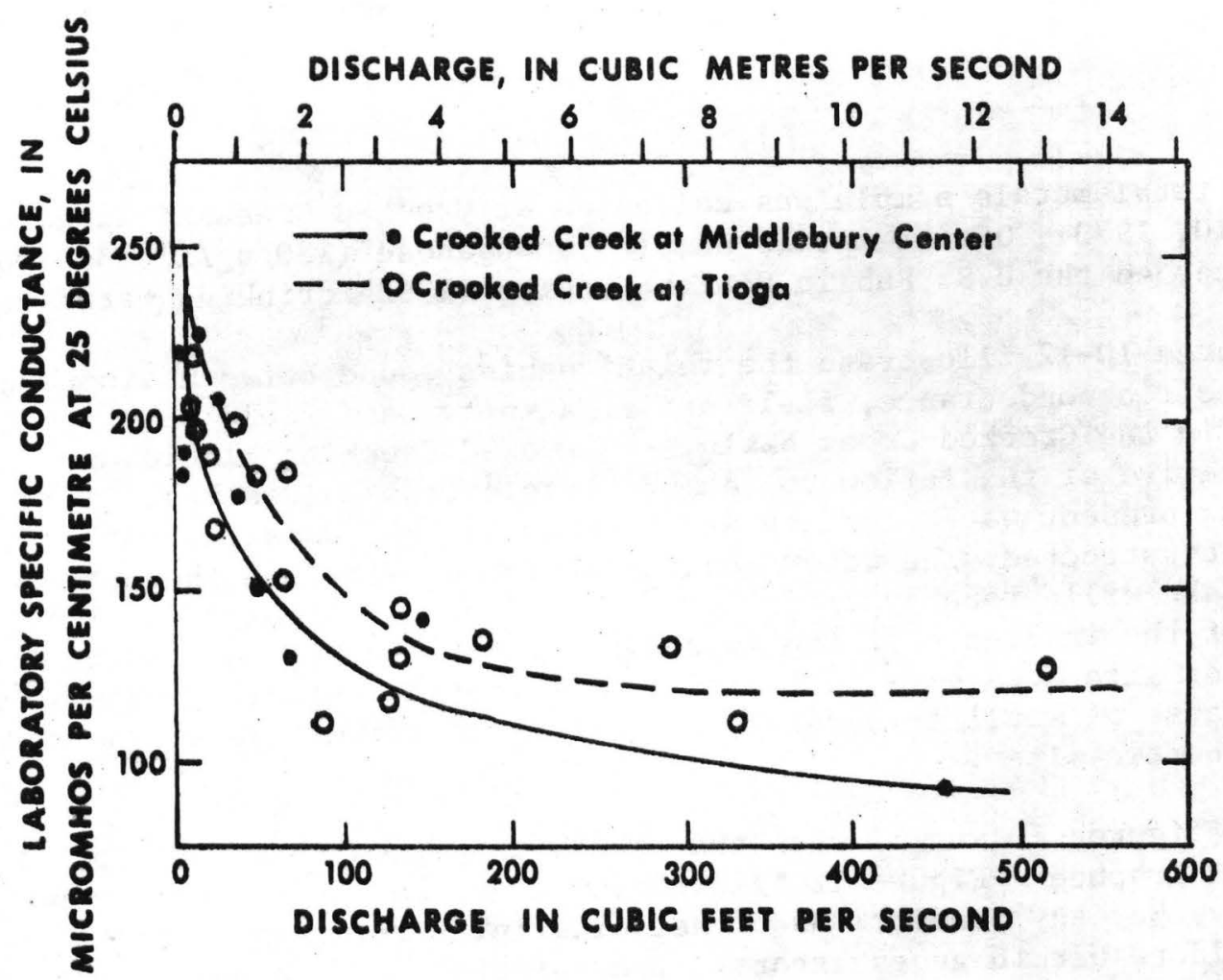

Figure 10,--Discharge versus laboratory specific conductance for section 2.

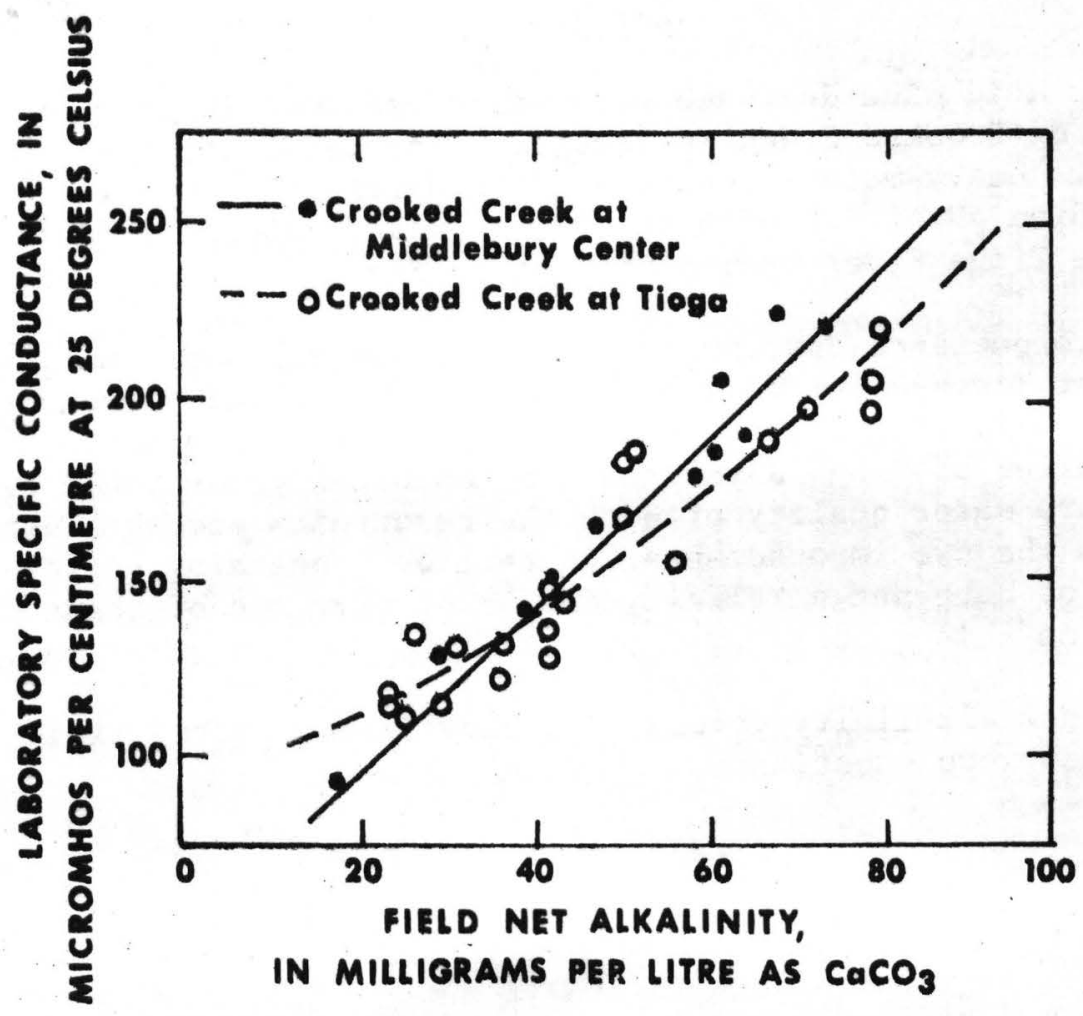

Figure 11.--Field net alkalinity versus laboratory specific conductance for section 2. 


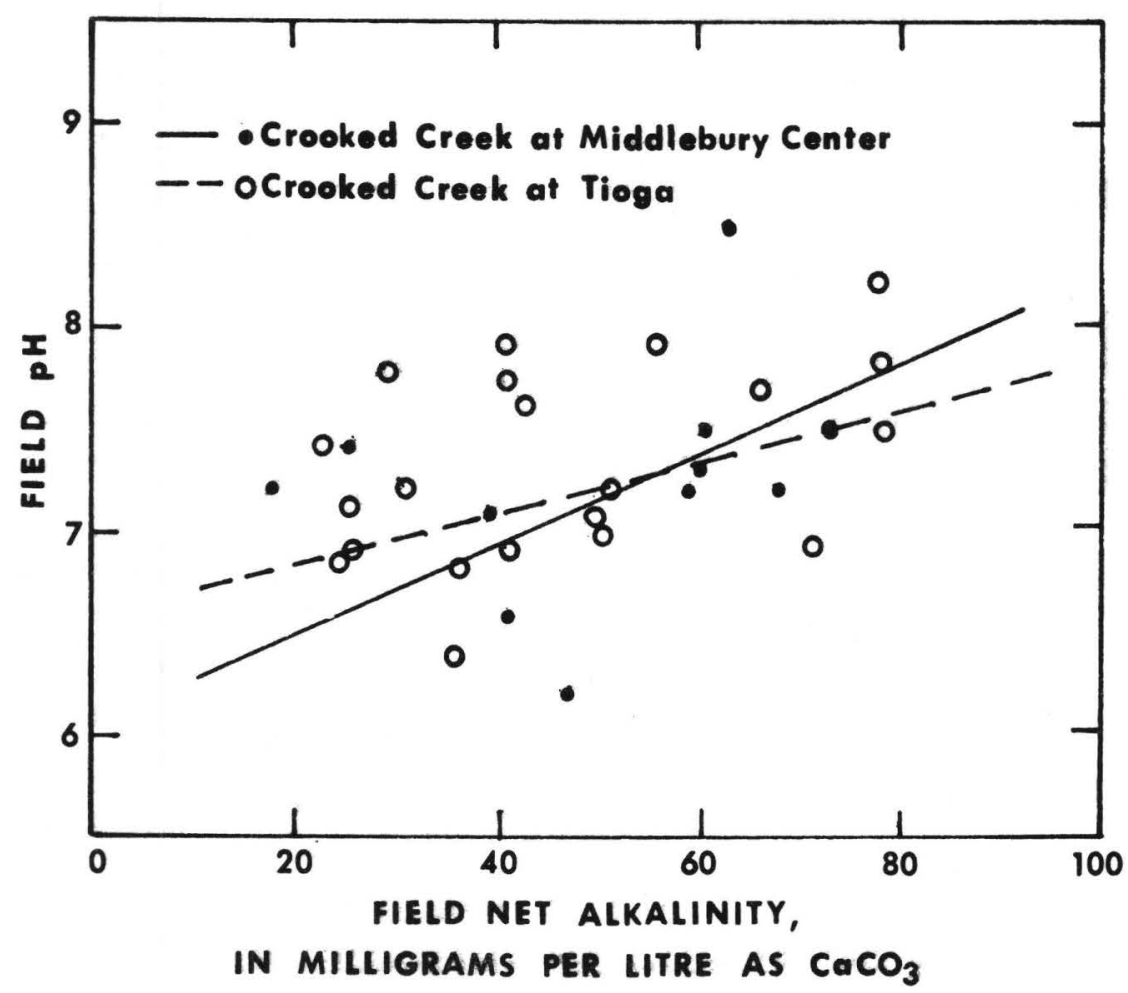

Figure 12.--Field net alkalinity versus field $p H$ for section 2.

\section{Section 4}

The water quality of the Cowanesque River was evaluated using six stations from Westfield to Lawrenceville. All of the stations but Cowanesque River near Lawrenceville were discontinued after one year of data collection. The Cowanesque River is not affected by acid mine drainage, but does feel the effects of domestic and industrial pollution from the city of Westfield. Figures 13 and 14 illustrate the changes found in the water quality of the Cowanesque River from above to below Westfield (Cowanesque River at Westfield and Cowanesque River at Cowanesque). The maximum values of specific conductance, total alkalinity, and chloride below Westfield are well above those found anywhere else in the basin. Mill Creek, which discharges into the Cowanesque River at Westfield, carries tannery wastes that apparently produce high chlorides and specific conductances (table 4). Occasional high alkalinities and nutrient loads have also been found, accompanied by algae blooms and noxious odors.

Cowanesque Lake may have many problems with algae blooms and weed growth because of the high alkalinity and nutrient loads in the Cowanesque River. The high alkalinities in the Cowanesque River should insure that the releases from Cowanesque Lake are sufficient to neutralize any acidity still present in the Tioga River at Lawrenceville. 
DISTANCE DOWNSTREAM FROM COWANESQUE RIVER AT WESTFIELD, IN KILOMETRES
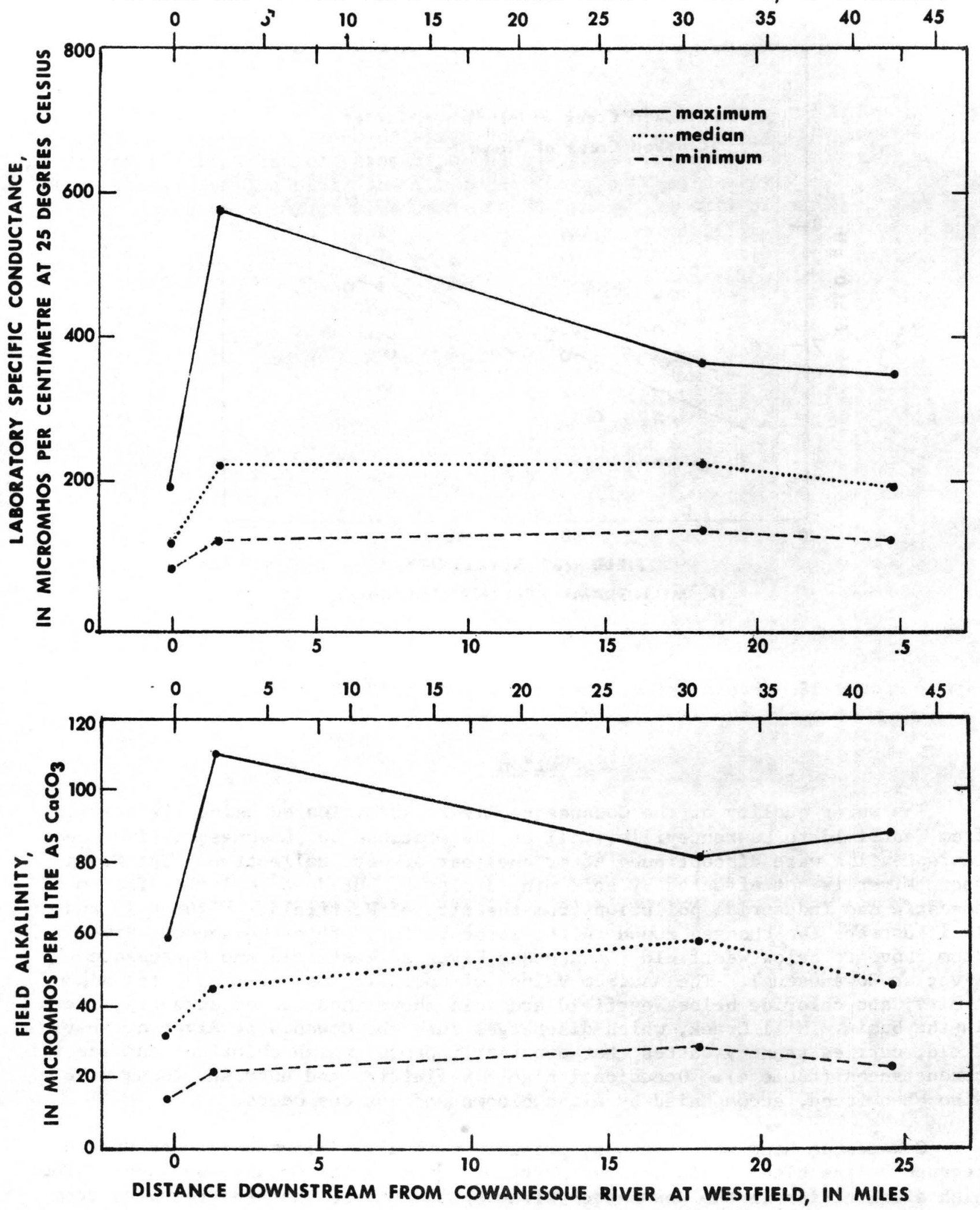

Figure 13.--Cowanesque River Zaboratory specific conductance and field alkalinity profiles. 
Water quality at Tioga River at Lindley is the best sampled along the Tioga River below Blossburg. Although the nutrients, total iron, and manganese still are excessively high, a minimum $\mathrm{pH}$ of 6.2 and field net alkalinity of 15 $\mathrm{mg} / 1$ assure aquatic life of a continuously favorable environment. A biological study by Barker (1972) showed 7 families of macroinvertebrates, including mayflies, caddis flies, dolson flies, riffle beetles, and 18 species of fish at Tioga River at Lindley as compared with 6 families of macroinvertebrates and 8 species of fish at Tioga River at Tioga Junction and only one macroinvertebrate family found at Tioga River at Tioga.

\section{TIOGA RIVER PROFILE}

Figures 15 through 18 give an overall view of the water quality in the Tioga River. The maximum, minimum, and median flows obtained during the study period September 1973 to May 1975 were exceeded 37 percent of the time when compared to the past 33 years of streamflow record. This indicates that flows during this particular study period were about 13 percent higher than the average for the past 33 years and that water quality may be slightly different during a year of normal or below-normal flow. The maximum and minimum values shown are important when considering the environment of aquatic life present in the stream. Median values represent those conditions which have existed most often throughout the study period. Contributions to the Tioga River from Mill Creek, Crooked Creek, and the Cowanesque River may be estimated by interpolating between the respective stations marked along the Tioga River.

A total of 13 metals samples were collected at the Tioga River stations, including 10 total-metal and 3 dissolved-metal samples. A total-metal sample represents the concentration of the metal contained in the dissolved phase plus an indeterminate amount of the metal which is adsorbed to or present as an integral part of the structure of minerals which comprise the particulate material. A dissolved metal sample consists of that concentration of the metal which passes through a 0.45 micrometer filter paper. No relationships between $\mathrm{pH}$ or net alkalinity and total metals can be established at this time. There was a general relationship between total metal concentration and discharge, but the points had a considerable amount of scatter as shown in figure 19 for the four Tioga River stations.

Total aluminum and total iron increase with increasing discharge, and total manganese and total zinc decrease with increasing discharge at all four Tioga stations. Usually, one would expect total metal concentrations to decrease with increasing discharge because of dilution effects both from increased runoff and tributary contributions. 
DISTANCE DOWNSTREAM FROM COWANESQUE RIVER AT WESTFIELD, IN KILOMETRES
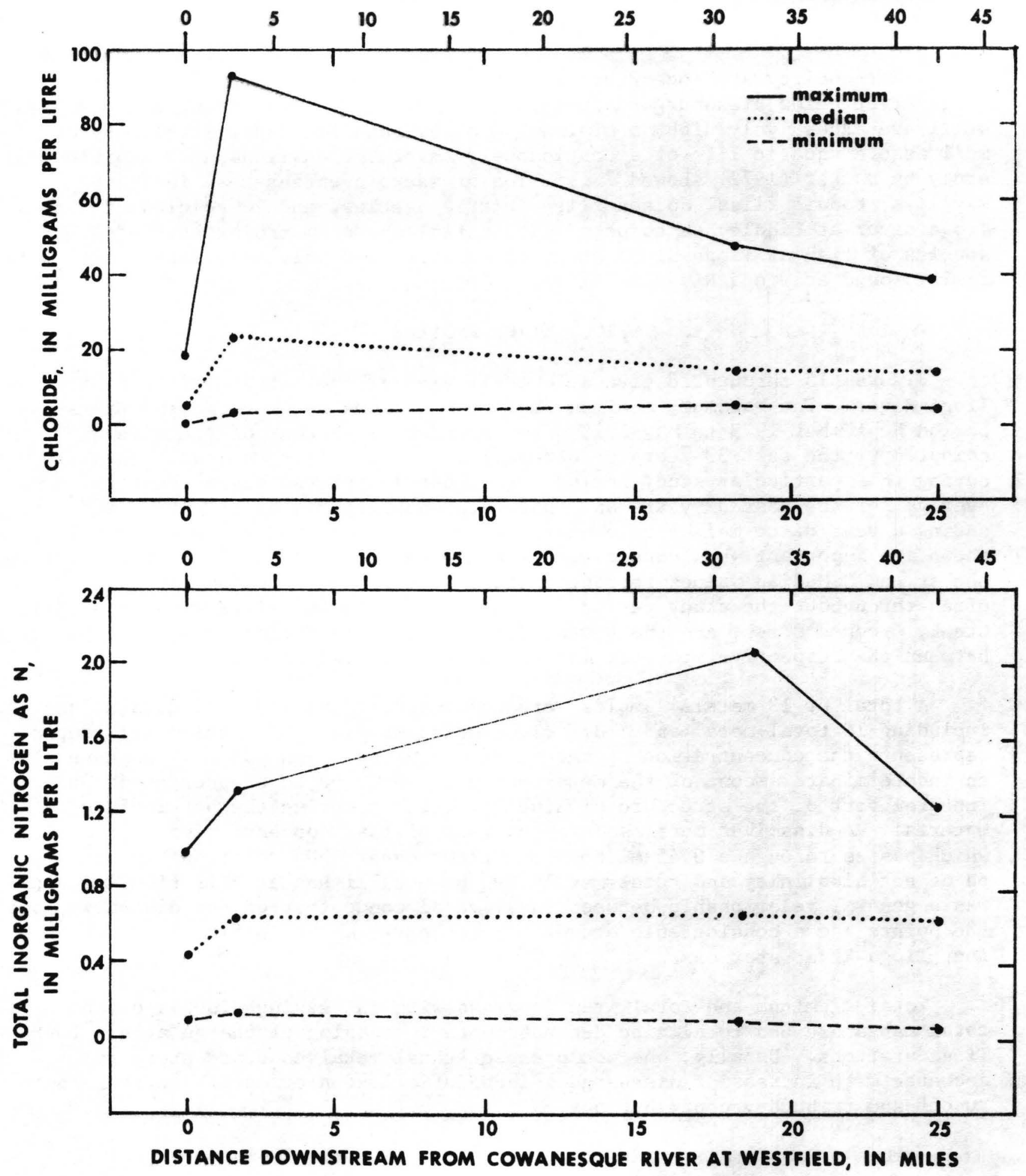

Figure 14.--Cowanesque River chloride and total inorganic nitrogen as $N$ profiles. 


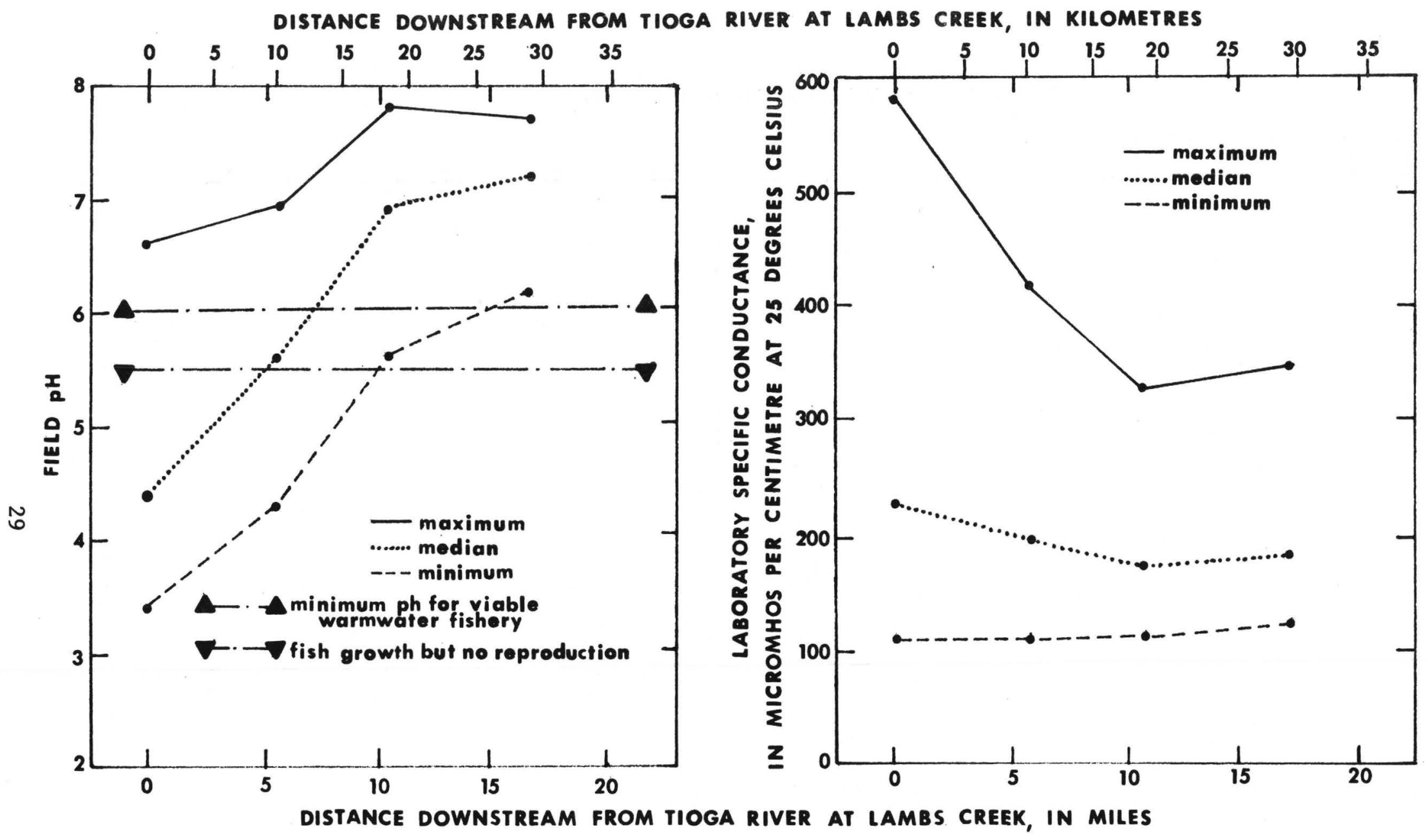

Figure 15.--Tioga River field $\mathrm{pH}$ and laboratory specific conductance profiles. 
DISTANCE DOWNSTREAM FROM TIOGA RIVER AT LAMBS CREEK, IN KILOMETRES
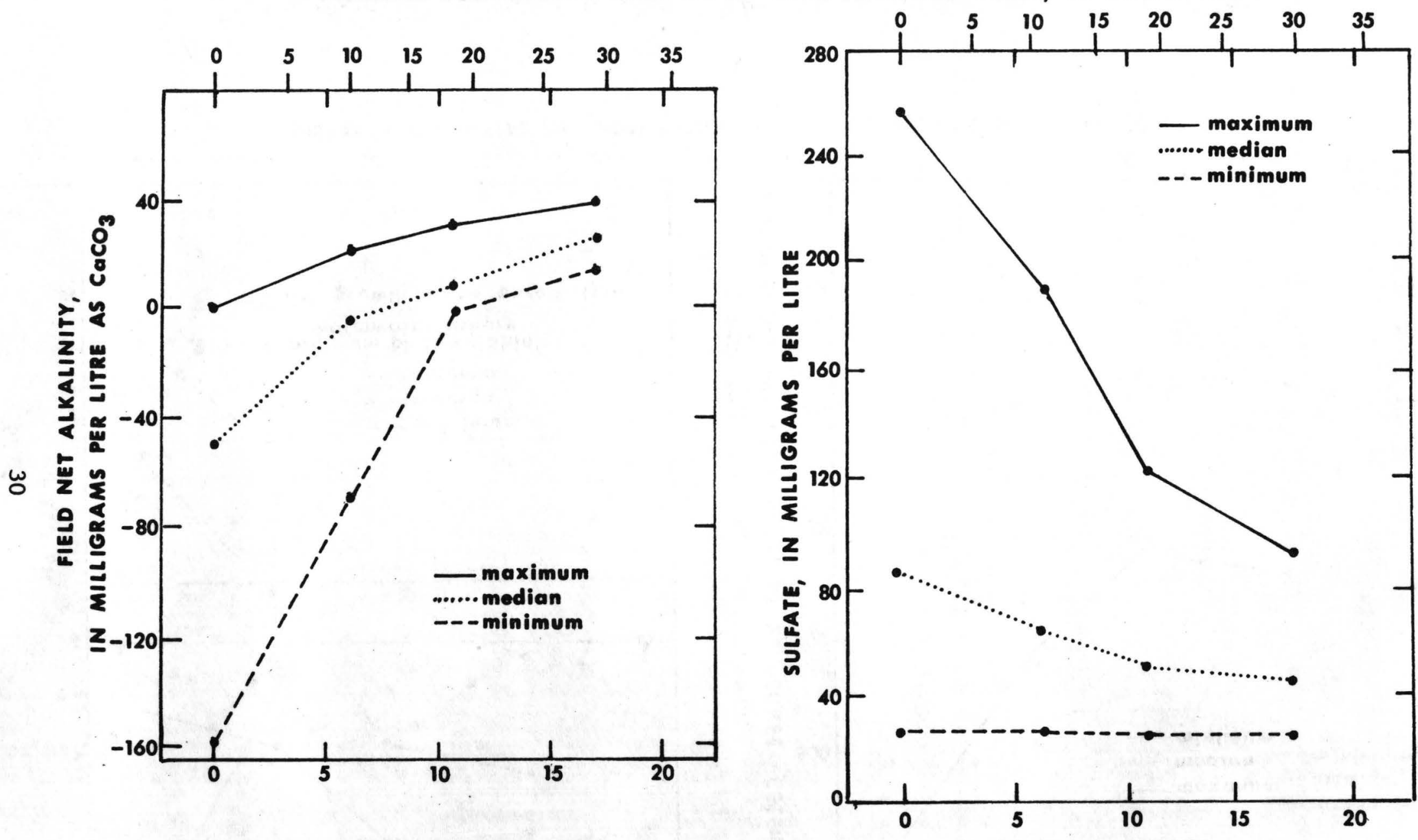

DISTANCE DOWNSTREAM FROM TIOGA RIVER AT LAMBS CREEK, IN MILES

Figure 16.--Tioga River field net alkalinity and sulfate profiles. 


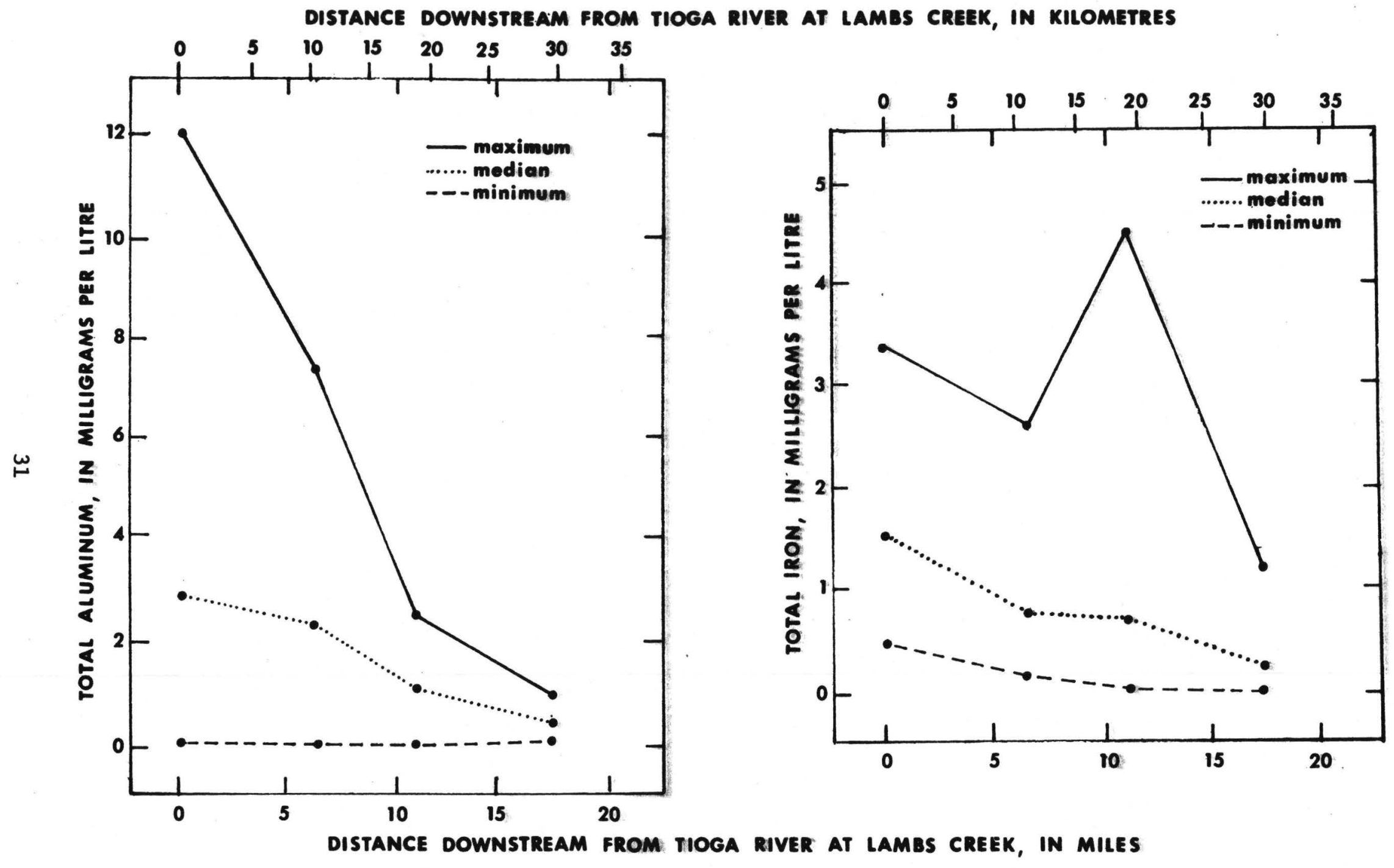

Figure 17.--Tioga River total aluminum and total iron profiles. 
DISTANCE DOWNSTREAM FROM TIOGA RIVER AT LAMBS CREEK, IN KILOMETRES
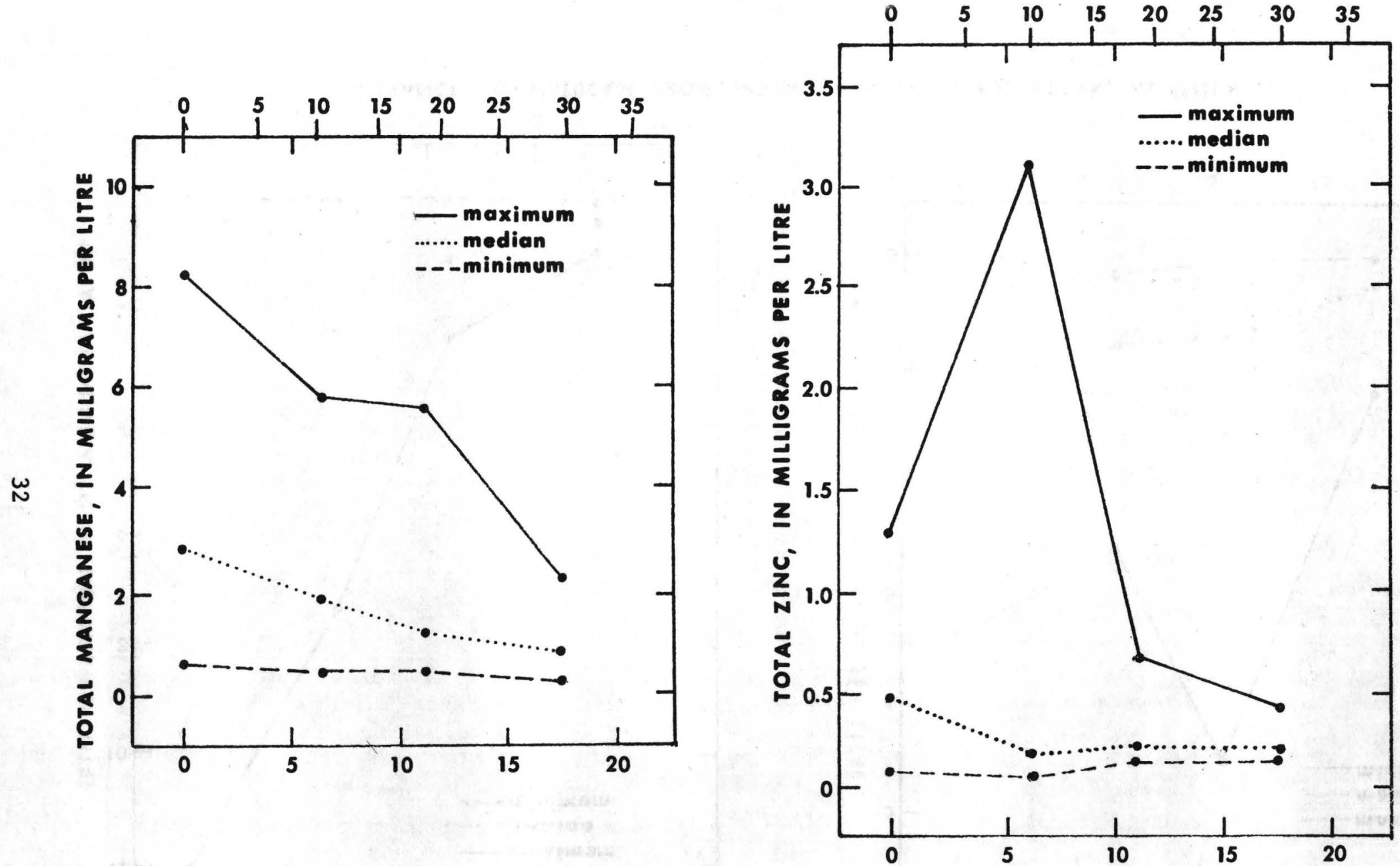

DISTANCE DOWNSTREAM FROM TIOGA RIVER AT LAMBS CREEK, IN MILES

Figure 18.--Tioga River total manganese and total zinc profiles. 


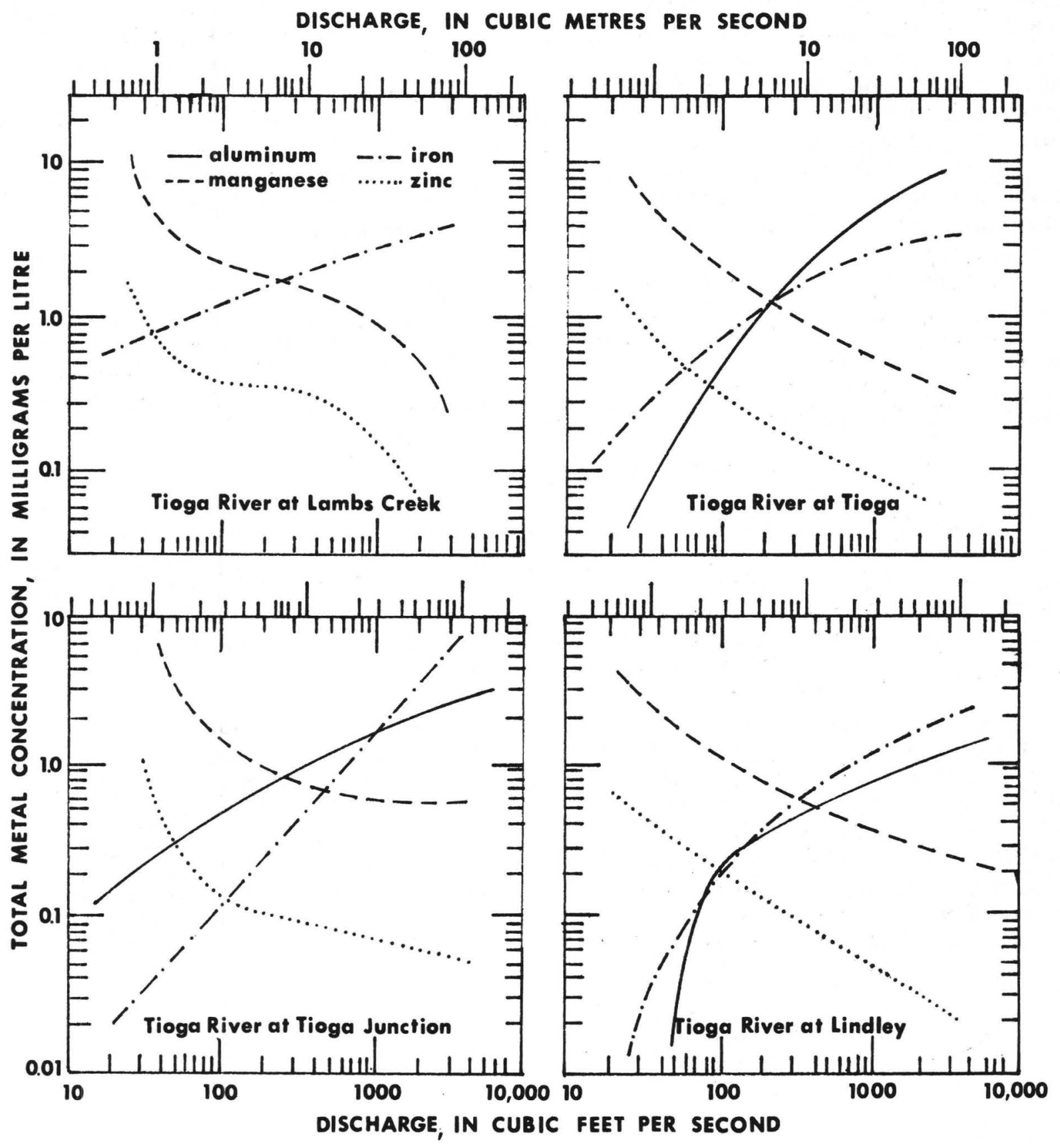

Figure 19.--Discharge versus total metal concentration for the Tioga River. 
One reason why total aluminum and iron concentrations increase with increasing discharge can be explained by solubility controls, The solubilities of aluminum and iron are much lower at the $\mathrm{pH}$ range found in the upper Tioga River than the solubilities of manganese and zinc. This implies first of all that probably a much larger percentage of aluminum and iron are in the suspended phase rather than in the dissolved phase. Secondly, the total concentrations of manganese and zinc are probably mostly in the dissolved phase. If that is the case, during low flows, when the $\mathrm{pH}$ is usually lowest, most of the iron and aluminum would precipitate, lowering the total amount detected, whereas mostly all of the manganese and zinc would continue downstream in the dissolved phase. As flows increase, total concentrations of manganese and zinc are decreased by dilution. Total iron and aluminum, on the other hand, increase because the increasing stream velocities transport some of the precipitate which had remained on the stream bottom, an effect called scouring.

Further samples of both dissolved- and total-metals are needed to either substantiate or disprove the above theory. More dissolved-metals samples will also further define the solubility controls at work in the Tioga River and the resulting mobilities of the different metals.

\section{BUFFER CAPACITY}

The buffering capability of water is an important parameter in both stream and reservoir water quality. As mentioned before, the Tioga and Hammond Lakes will be connected by a weir. The mixing capabilities of the Tioga River and Crooked Creek waters are important variables that need to be defined in order to assess the water quality of both the Tioga and Hammond Lakes and the Tioga River downstream from the dams after impoundment.

The buffering capacity of a solution is measured by its ability to accept $\mathrm{H}^{+}$or $\mathrm{OH}^{-}$ions while resisting significant $\mathrm{pH}$ changes. In natural water, the main dissolved constituents which contribute to buffering capacity are the carbon dioxide species. Figure 20 is a graph of $\mathrm{pH}$ vstog concentration (molar) which shows the distribution of the different ions in the carbonate equilibria at varying $\mathrm{pH} ; \mathrm{H}^{+}$and $\mathrm{OH}^{-}$are also shown as minor variables in buffering capacity. The graphs are determined from the three equations shown below where $\mathrm{K}_{1}$ and $\mathrm{K}_{2}$ are the dissociation constants of carbonate and $\mathrm{K}_{\mathrm{w}}$ is the dissociation constant of water.

$$
\begin{aligned}
& \mathrm{K}_{1}=\frac{\left[\mathrm{H}^{+}\right]\left[\mathrm{HCO}_{3}^{-}\right]}{\left[\mathrm{H}_{2} \mathrm{CO}_{3}\right]}=10^{-6.4}, \mathrm{pK}_{1}=6.4 \\
& \mathrm{~K}_{2}=\frac{\left[\mathrm{H}^{+}\right]\left[\mathrm{CO}_{3}^{2-}\right]}{\left[\mathrm{HCO}_{3}^{-}\right]}=10^{-10.3}, \mathrm{pK}_{2}=10.3 \\
& \mathrm{~K}_{\mathrm{w}}=\frac{\left[\mathrm{H}^{+}\right]\left[\mathrm{OH}^{-}\right]}{\left[\mathrm{H}_{2} \mathrm{O}\right]}=10^{-14}, \mathrm{pK}_{\mathrm{w}}=14
\end{aligned}
$$




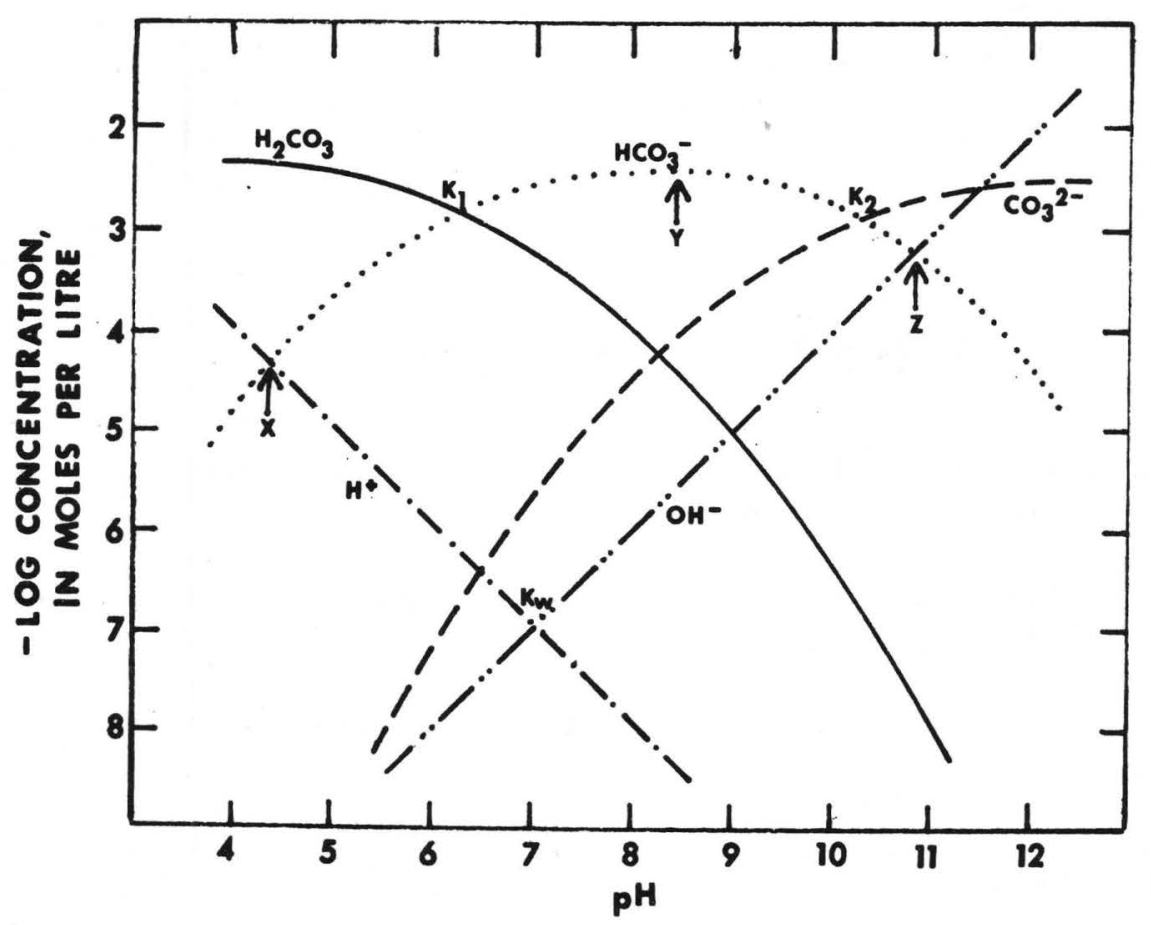

Figure 20.--pH versus - Iog concentration showing the relationships of $\mathrm{CO}_{3}^{2-}, \mathrm{HCO}_{3}^{-}, \mathrm{H}_{2} \mathrm{CO}_{3}, \mathrm{OH}^{-}$, and $\mathrm{H}^{+}$.

Alkalinity (the ability to accept protons) and acidity (the ability to donate protons) were determined by titrating a sample with a strong acid $(0.01639 \mathrm{~N}$ $\left.\mathrm{H}_{2} \mathrm{SO}_{4}\right)$ or a strong base $(0.0248 \mathrm{~N} \mathrm{NaOH})$, respectively. The endpoints of the titrations are designated by an $x$ in figure 20 at the alkalinity titration endpoint ( $\mathrm{pH}$ 4.5) and $a \mathrm{y}$ at the acidity titration endpoint ( $\mathrm{pH} \mathrm{8.3).} \mathrm{Any}$ water samples with an initial $\mathrm{pH}$ below 4.5 or above 8.3 were titrated for only acidity or alkalinity, respectively. Water samples may contain both alkalinity and acidity at the same time. For a sample having a pH between 4.5 and 8.3, two aliquots were titrated. One was titrated to $\mathrm{pH} 4.5$ with standard acid and one portion was titrated to $\mathrm{pH} \mathbf{8 . 3}$ using standard base. The acidity calculated, expressed as milligrams per liter as $\mathrm{CaCO}_{3}$, is defined as a negative quantity. The alkalinity calculated from the titration of the other aliquot, also expressed as milligrams per liter as $\mathrm{CaCO}_{3}$, was termed a positive quantity. Algebraic addition of the two quantities provides an index (here called net alkalinity) which allows one to directly calculate the effect of mixing water having a given level of alkalinity with a water having less alkalinity or even acidity. 
Predictions of net alkalinity load from the mixture of two different waters 1 and 2 to give the net alkalinity load of water 3 is generally a conservative procedure according to the equation given below:

$$
\text { Net alkalinity } \operatorname{load}_{3}=\frac{\left(Q_{1} \times \text { net alkalinity } 1\right)+\left(Q_{2} \times \text { net alkalinity } 2\right)}{Q_{1}+Q_{2}}
$$

where $Q_{1}$ and $Q_{2}$ represent discharges at sites 1 and 2 . In the equation the flows of waters 1,2 , and 3 are assumed to be relatively constant over the sampling period.

The above procedure was followed for three stream junctions in the Tioga River basin using the following stations (fig. 3):

Tioga River at Lambs Creek + Mill Creek near Tioga = Tioga River at Tioga

Tioga River at Tioga + Crooked Creek at Tioga = Tioga River at Tioga Junction

Tioga River at Tioga Junction + Cowanesque River near Lawrenceville = Tioga River at Lindley

Graphs relating the observed net alkalinity load to the calculated net alkalinity load according to the above formula were constructed and are shown in figures 21 and 22 .

The curves in figure 21 deviate from the calculated values shown by the dashed line because of alkaline contributions from small tributaries between the sites and because of the following assumptions: (1) a relationship between net alkalinity and discharge holds for each tributary contribution, and (2) the relation of the discharge of each tributary to that at a measured station downstream remains constant over the sampling period. More accurate determinations would require that contributions from each tributary between sites 1 and 2 and site 3 be measured for alkalinity and acidity.

Figure 22 shows a slightly different deviation than that in figure 21. The calculated net alkalinity load is lower than the true net alkalinity load at the extreme ends of the scale, while the calculated net alkalinity load is higher than the true load in the middle of the scale. Most of the values plotted on the graph were measured on two consecutive days, thus increasing the amount of error in the calculations by allowing more time for the measured discharges and net alkalinities to fluctuate between measurements. This relationship should be further refined before it can be reliably used. 

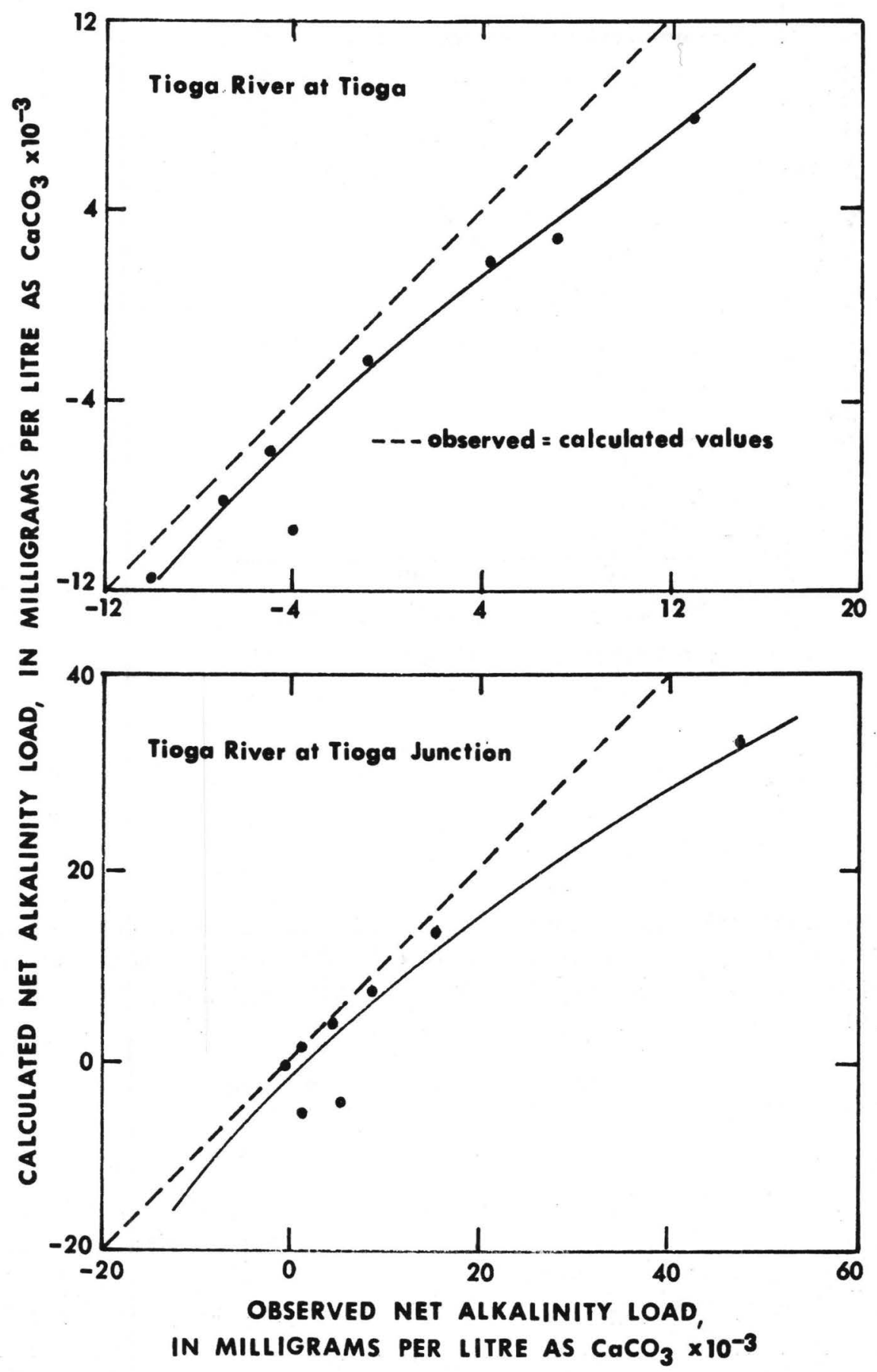

Figure 21.--Observed versus calculated net alkalinity loads for Tioga River at Tioga and Tioga River at Tioga Junction. 


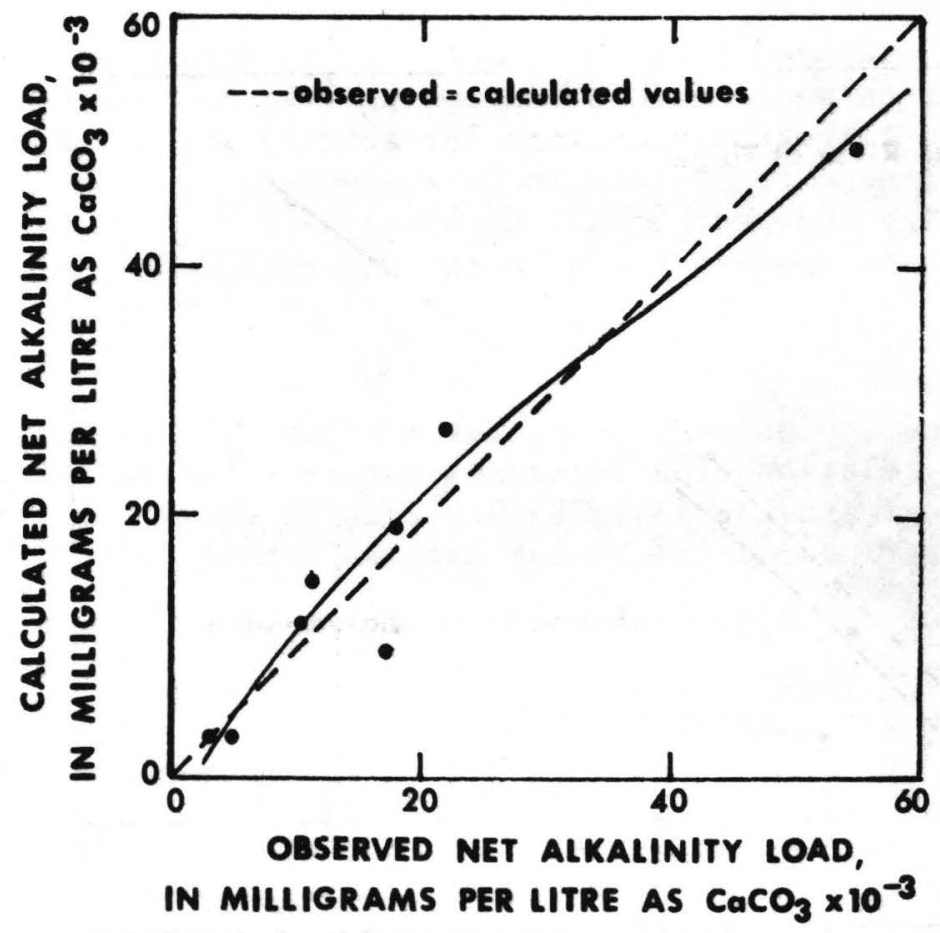

Figure 22.--Observed versus calculated net alkalinity loads for Tioga River at Lindley.

Using the assumptions made above, the resultant net alkalinity load at site 3 can be calculated and the true net alkalinity load picked off the appropriate graph. The net alkalinity concentration can then be calculated from the equation below:

$$
\text { Net alkalinity } \text {, }_{3}=\frac{\text { true net alkalinity } \operatorname{load}_{3}}{Q_{3}}
$$

The prediction of $\mathrm{pH}$ of a resultant stream from the calculations of net alkalinity is complex. The $\mathrm{pH}$ of a solution is defined as the negative $\log _{10}$ of the hydrogen ion activity (molal). For a given partial pressure of carbon dioxide $\left(\mathrm{PCO}_{2}\right), \mathrm{pH}$ is a function of net alkalinity. Therefore, a general relationship can be constructed between $\mathrm{pH}$ and net alkalinity (fig. 23). In natural waters, however, $\mathrm{PCO}_{2}$ may vary due to the aeration of the stream, temperature of the water, the amount of $\mathrm{CO}_{2}$ consumed by photosynthesis or produced by respiration, etc. Thus, the scatter of the points in fig. 23 may be a result of the variation of $\mathrm{PCO}_{2}$. 
Until a model is developed from which accurate estimates of the quantity of $\mathrm{CO}_{2}$ in the water can be made, predictions of $\mathrm{pH}$ from net alkalinity are less than satisfactory. The titration endpoints for acidity and alkalinity 8.3 and 4.5, respectively, will need to be redefined because the endpoints of the titration for determining the true amount of alkalinity and acidity in the water sample vary with the amount of $\mathrm{CO}_{2}$ in the water.

\section{DISCUSSION}

The Tioga River and its major tributaries were sampled monthly from September 1973 to May 1975. The relationships developed for selected water-quality parameters in this report provide insight into present water quality. The relationships will be refined as additional samples are collected.

The sampling results included in this report partly satisfy the first object of this study, the assessment of preimpoundment water quality in the Tioga River basin. The data are used not only to define present water quality but also to indicate water quality in the three impoundments proposed for the area. The data suggest that:

(1) Tioga Lake will have an inflow water quality similar to that of Tioga River at Lambs Creek. Mill Creek and Hammond Lake will contribute alkaline water with relatively low concentrations of dissolved solids to the impoundment. The effects of these contributions cannot be predicted, as yet. Outflow water quality will probably change from that now observed at the proposed damsite because of the effects of the impoundment and the added contributions from Hammond Lake via the connecting weir.

(2) Hammond Lake will be an alkaline lake which will probably support a warm-water fishery. Problems may develop with nuisance algae blooms, depending on the size and depth of the lake.

(3) Cowanesque Lake will be an alkaline impoundment probably supporting a diversified fish population. The lake will probably be affected by algae blooms. Dissolved oxygen concentrations may get quite low, controlling the level of aquatic life in the lake.

The conclusions drawn above are only general interpretations from the data obtained during this part of the study. The data in this report and future data will be used to develop a more precise picture of water quality for the basin. Unusual characteristics observed throughout the sampling period will be investigated. Optimally, both the future stream and lake water quality will be incorporated into a predictive water-quality model which will be used to assess key water-quality constituents and characteristics at selected locations throughout the study area. 


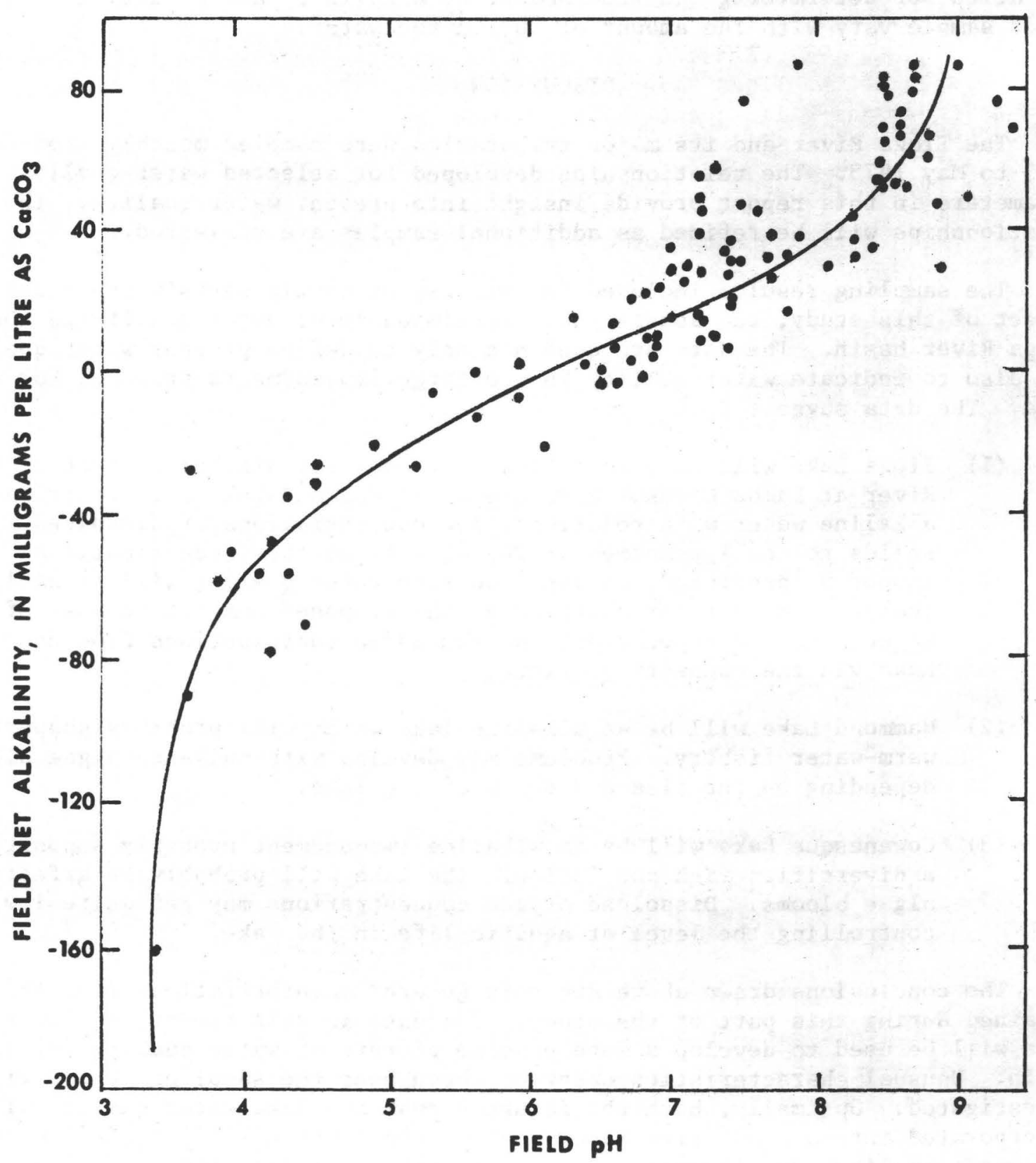

Figure 23.--Field pH versus field net alkalinity for the Tioga River basin. 


\section{SELECTED REFERENCES}

American Public Health Association and others, 1971, Standard methods for the examination of water and wastewater [13th edition]: New York, Am. Public Health Assoc., 874 p.

Barker, J. L., 1972, Effects of acid mine drainage on fish and macroinvertebrates of the Tioga River, Pennsylvania and New York: U.S. Geological Survey Open-File Report, 17 p.

Brown, Eugene, Skougstad, M. W., and Fishman, M. J., 1974, Methods for collections and analysis of water samples for dissolved minerals and bases: U.S. Geological Survey Techniques Water-Resources Inv., book 5, chap. A1, 160 p.

Cline, J. T., and Balla, Ruth, 1975, Water quality relationship as a function of acid mine drainage and sewage inputs into the Susquehanna River: Environmental Sci. Dept., Wilkes College, Pa., p. 8-14.

Garrels, R. M., and Christ, C. L., 1965, Solution, minerals and equilibria: New York, Harper and Row, p. 74-92.

Moran, R. E., and Wentz, D. A., 1974, Effects of meta1-mine drainage on water quality in selected areas of Colorado, 1972-73: Colorado Resources Circ. no. 25,38 p.

Sawyer, C. N., 1947, Fertilization of lakes by agricultural and urban drainage: Journal New England Water Works Assoc., vol. 61, no. 2, p. 109-127.

Strumm, Werner, and Morgan, J. J., 1970, Aquatic chemistry, an introduction emphasizing chemical equilibria in natural waters: New York, John Wiley and Sons, Inc., p. 118-160.

U.S. Army Corps of Engineers, 1972, Occurrence and effects of mine drainage in the Tioga River basin: U.S. Army Corps of Engineers, Baltimore Dist., $104 \mathrm{p}$.

, 1974, Susquehanna mine drainage study, interim report, Tioga River

basin: U.S. Army Corps of Engineers, Baltimore Dist., 309 p.

U.S. Federal Water Pollution Control Administration, 1969, Water supply and water quality control study (Tioga-Hammond-Cowanesque Reservoirs): U.S. Federal Water Pollution Control Admin. Middle Atlantic Region.

U.S. Public Health Service, 1962, Drinking water standards, 1962: U.S. Public Health Service Pub. 956, 61 p.

Wilkes College Research and Graduate Center, 1968, Studies on the kinetics of iron (II) oxidation in mine drainage: Wilkes College Research and Graduate Center, Wilkes-Barre, Pa., September 1968, (mimeograph). 
Table 6.--Water quality results for the Tioga River basin, September 1973 to May 1975.

01516350 TIOGA RIVER NEAR MANSFIELD, PA.

CHEMICAL ANALYSES

(Milligrams per litre unless otherwise noted)

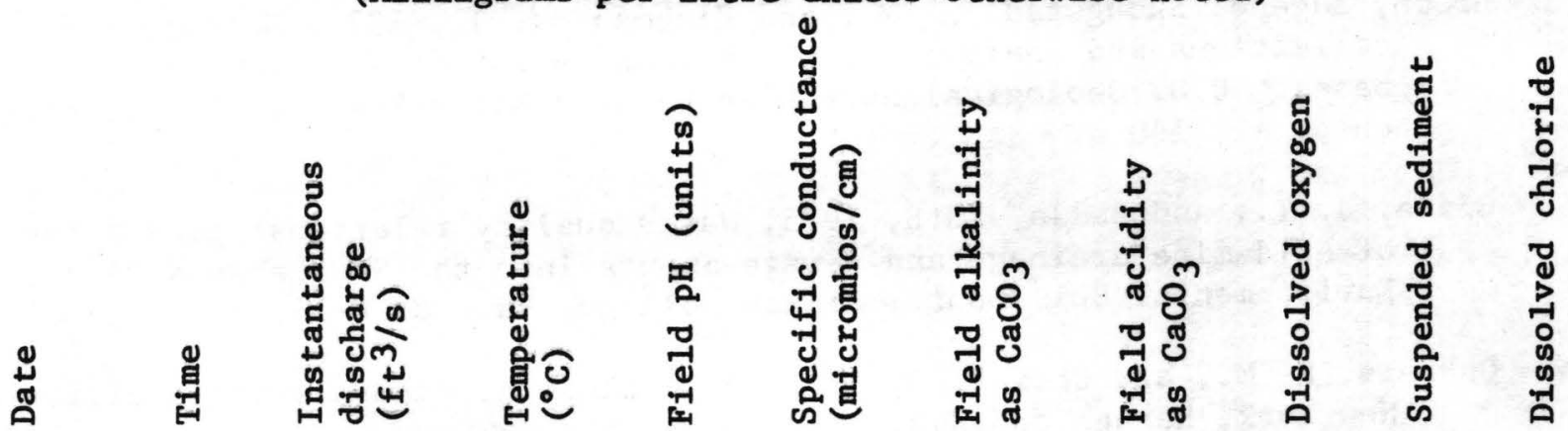

1975

May $14 \quad 0830$

$\begin{array}{llll}267 & 10.5 \quad 5.6 \quad 163\end{array}$

3

$14 \quad 10.4 \quad 24$

3.0

(Micrograms per litre)

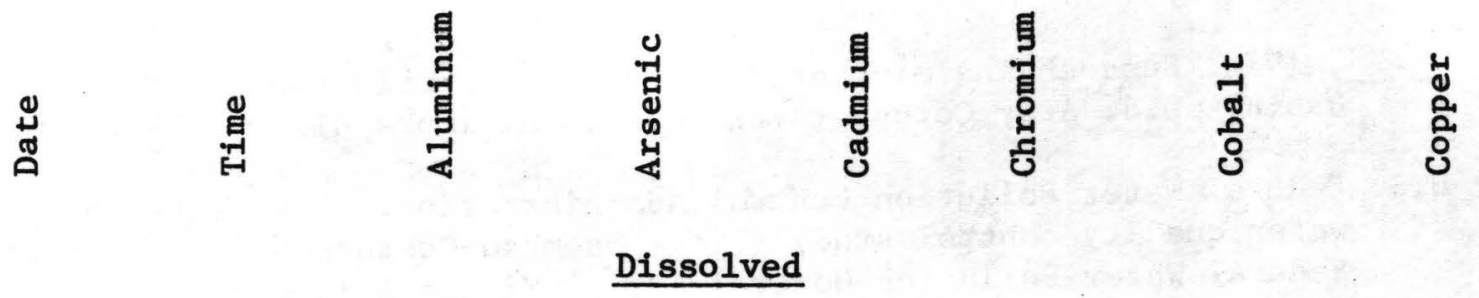

1975

May 14

0830

810

1

$0 \quad 10$

19

10 
蝔哭

N

Iron

ఉ

Date

L Lead
๒

崔

$\mapsto \quad$ Selenium

- Silver

응 Zinc
Date

ํ Dissolved sulfate

N Bicarbonate

- Carbonate

- Ammonia nitrogen

¿ as $\mathrm{N}$

i Total nitrate

N as $\mathrm{N}$

- Total inorganic

$\stackrel{\omega}{\omega} \quad$ nitrogen as $\mathrm{N}$

: $\quad$ Total organic nitrogen as $\mathrm{N}$

- Total nitrogen as $\mathrm{N}$

官

Total phosphorus
as $\mathrm{P}$

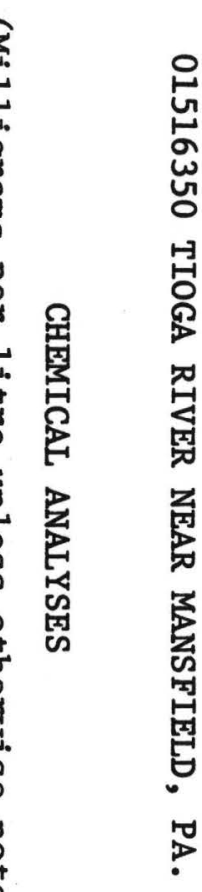

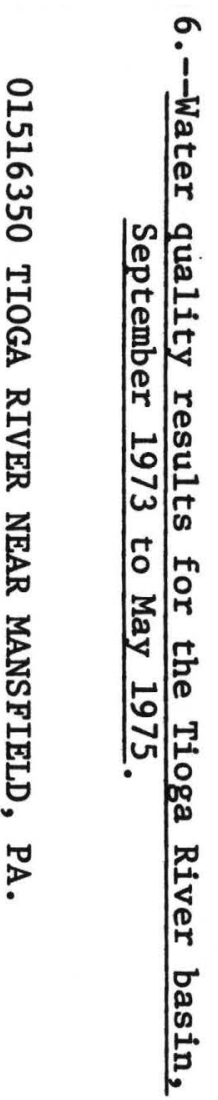

\& Total orthophosphorus as $\mathrm{P}$ 
Table 6.--Water quality results for the Tioga River basin,

September 1973 to May 1975--Continued.

01516820 TIOGA RIVER AT LAMBS CREEK, PA.

CHEMICAL ANALYSES

(Milligrams per litre unless otherwise noted)
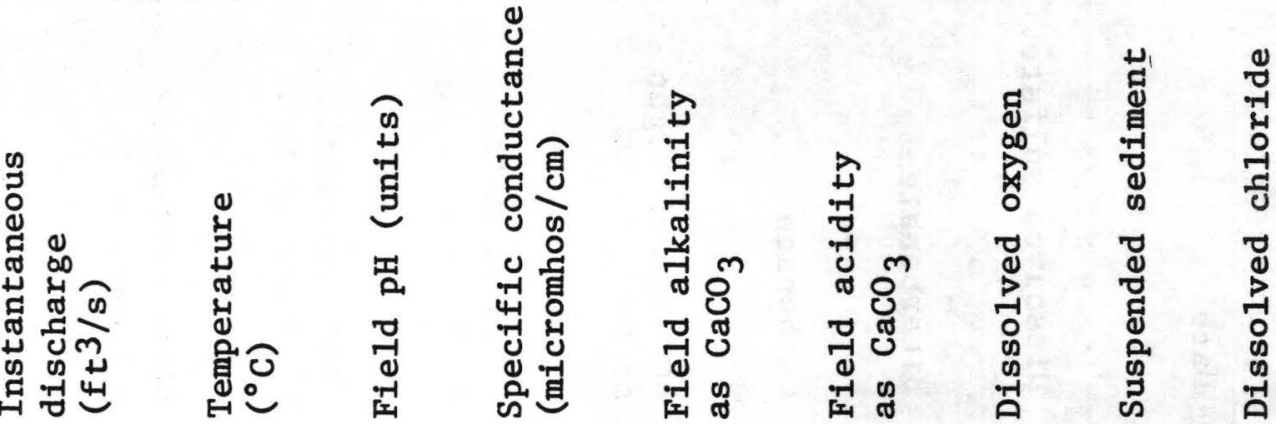

1973

\begin{tabular}{|c|c|c|c|c|c|c|c|c|c|c|}
\hline & & & & & & & & & & \\
\hline Sep. 06 & 1100 & 216 & 22.0 & 4.5 & 265 & 0 & 29 & 11.5 & 336 & 7.5 \\
\hline Oct. 09 & 1430 & 73 & 15.5 & 4.1 & 349 & 0 & 55 & 9.8 & 4 & 8.5 \\
\hline Nov. 08 & 0910 & 149 & 3.0 & 4.6 & 223 & -- & 24 & 12.4 & 16 & 4.0 \\
\hline Dec. 13 & 1145 & 392 & 1.5 & 4.8 & 208 & -- & 26 & 13.1 & 47 & 2.5 \\
\hline 1974 & & & & & & & & & & \\
\hline Jan. 10 & 1015 & -- & .0 & 4.6 & 250 & -- & 22 & 14.0 & 14 & 7.3 \\
\hline Feb. 13 & 1315 & -- & .5 & 4.6 & 207 & -- & 24 & -- & 42 & 6.5 \\
\hline Mar. 13 & 1315 & -- & 1.0 & 4.2 & 173 & 0 & 77 & 13.4 & 23 & 4.5 \\
\hline Apr. 02 & 1130 & 1250 & 3.0 & 5.9 & 141 & -- & 24 & 12.8 & 153 & 5.0 \\
\hline May 01 & 1215 & 285 & 14.0 & 5.1 & 172 & -- & 33 & 9.9 & 20 & 5.6 \\
\hline June 12 & 1230 & 96 & 18.5 & 4.6 & 223 & -- & 50 & 9.4 & 14 & 5.5 \\
\hline July 17 & 1630 & 40 & 26.0 & 3.4 & 416 & 0 & 160 & 7.6 & 1 & 10 \\
\hline Aug. 14 & 1245 & 29 & 26.0 & 3.5 & 570 & -- & -- & 7.4 & 2 & 8.0 \\
\hline Sep. 12 & 1230 & 29 & 22.0 & 3.6 & 587 & 0 & 89 & 8.8 & E0 & 10 \\
\hline Oct. 10 & 1350 & 33 & 12.0 & 3.8 & 457 & 0 & 58 & 10.4 & EO & 9.0 \\
\hline Nov. 07 & 0830 & 136 & 8.0 & 6.5 & 19.7 & 10 & 12 & 11.8 & 22 & 6. \\
\hline Dec. 09 & 1210 & 1500 & 2.5 & 5.9 & 109 & 11 & 16 & 12.8 & 88 & 25 \\
\hline 975 & & & & & & & & & & \\
\hline Jan. 14 & 1245 & 492 & .0 & 3.6 & 199 & 0 & 27 & 13.2 & 29 & 5.0 \\
\hline Feb. 03 & 1230 & 180 & .5 & 3.9 & 274 & 0 & 50 & 12.6 & 9 & 5. \\
\hline Mar. 05 & 1215 & 228 & 1.0 & 4.3 & 256 & 0 & 55 & 12.8 & 32 & 5.0 \\
\hline Apr. 01 & 1200 & 231 & 6.0 & 4.2 & 185 & 0 & 47 & 12.0 & 13 & 5.0 \\
\hline May 14 & 1115 & 376 & 13.5 & 6.6 & 161 & 6 & 7 & 9.8 & 26 & \\
\hline
\end{tabular}

E - Estimated. 
Table 6.--Water quality results for the Tioga River basin, September 1973 to May 1975--Continued.

01516820 TIOGA RIVER AT LAMBS CREEK, PA.

CHEMICAL ANALYSES

(Milligrams per litre unless otherwise noted)

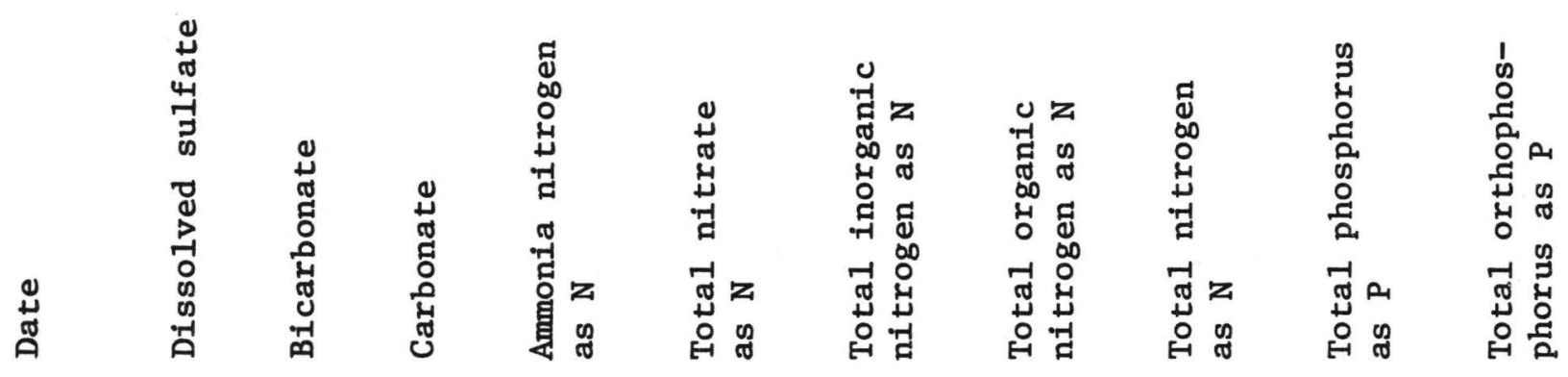

1973

Sep. 06

0ct. 09

Nov. 08

Dec. 13

$106 \quad 0 \quad 0$

$134 \quad 0 \quad 0$

9800

76

\section{4}

Jan. 10

Feb. 13

Mar. 13

Apr. 02

May 01

June 12

July 17

Aug. 14

Sep. 12

Oct. 10

Nov. 07

Dec. 09

71

82

61

35

66

106

143

256

118

188

81

2

1975

Jan. 14

Feb. 03

Mar. 05

Apr. 01

May 14
.41
.05

$\begin{array}{rr}2.01 & .56 \\ .28 & .31 \\ .36 & .17 \\ .73 & .27\end{array}$

2.6
.05

.14

1.6

.23

.29

.59

.59

.53

1.0

.10

.29

.04

.11

.04

.02

.10

$.03 \quad .29$

\section{1}

1.2

1.0

1.6

.72

.97

.47

.75

.72

.58

.59

1.1

$\begin{array}{ll}.75 & .35\end{array}$

.61

.16

.19

.23

.91

.08

$.33 \quad .13$
1.0

1.1

.84

.46
.03

.01

.01

.10

.11

.09

.02

.01

.00

.01

.01

.07

$\begin{array}{ll}.07 & .02 \\ .07 & .05\end{array}$

$\begin{array}{ll}.07 & .02 \\ .07 & .05\end{array}$
.11

.03

.05

.03

.03 
Table 6.--Water quality results for the Tioga River basin, September 1973 to May 1975--Continued.

01516820 TIOGA RIVER AT LAMBS CREEK, PA.

CHEMICAL ANALYSES

(Micrograms per litre)

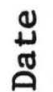

禀

•.

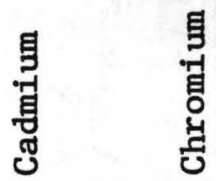

ơ

\section{Dissolved}

1974

Feb. 13

Mar. 13

Apr. 02

1315

1315

1130

1975

Mar. 05

Apr. 01

$1215 \quad 3000$

$1200 \quad 1800$

$1115 \quad 50$

1

0

0

May 14

\section{Tota1}

1974

May 01

June 12

July 17

Aug. 14

Sep. 12

Oct. 10

Nov. 07

Dec. 09

$1215 \quad 2300$

$1230 \quad 20$

$1630 \quad 3500$

$1245 \quad 12000$

$1230 \quad 5500$

$1350 \quad 5300$

$0830 \quad 3100$

$1210 \quad 1600$

1
2
$<1$
0
1
$<1$
0
3

1

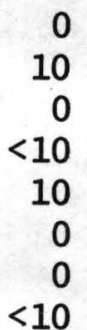

28

30

20

40

40

50

30

10

20

10

0

1975

Jan. 14

1245

2700

Feb. 03

1230

210

1
2

1
1

0

56 
Table 6.--Water quality results for the Tioga River basin, September 1973 to May 1975--Continued.

01516820 TIOGA RIVER AT LAMBS CREEK, PA.

CHEMICAL ANALYSES

(Micrograms per litre)

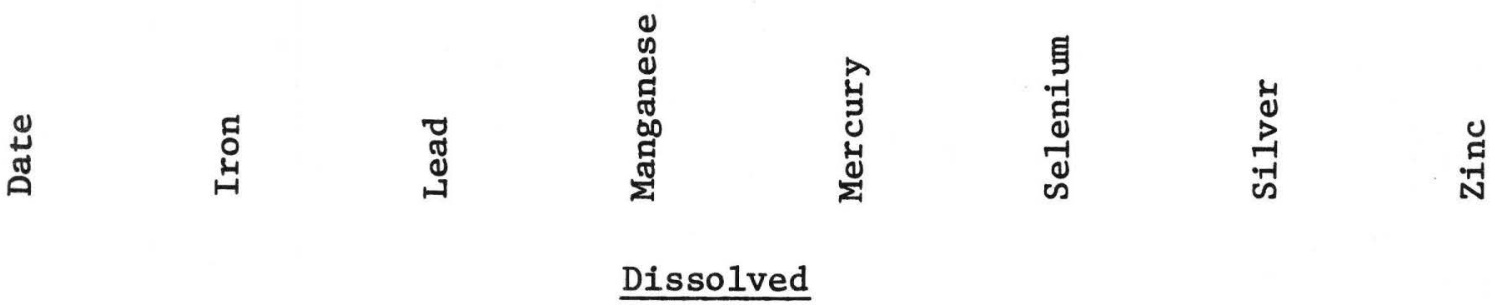

1974

Feb. 13

Mar. 13

Apr. 02

120

1200

70

1975

Mar. 05

Apr. 01

May 14
1600

590

180
6

0

1
$<.5$

$<.5$

$<.5$ $\overline{--}$

1
1
0

0

390

1700

1200

0

250

$0 \quad 150$

\section{Tota1}

\section{4}

May 01

June 12

July 17

Aug. 14

Sep. 12

Oct. 10

Nov. 07

Dec. 09

2100

1000

1400

500

1100

1500

1600

3400

\section{5}

Jan. 14

Feb. 03
2800

3000
88

3

3

6

7

2

3

4

$4 \quad 2000$

$5 \quad 3100$

1800
610
$<.5$

$<.5$

$<.5$

$<.5$

$<.5$

.8

$<.5$

$<.5$
$<.5$

$<.5$

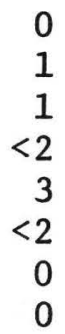

0
1
1
$<2$
3
$<2$
0
0

1

0 
Table 6.--Water quality results for the Tioga River basin, September 1973 to May 1975--Continued.

01517500 MILL CREEK NEAR TIOGA, PA.

CHEMICAL ANALYSES

(Milligrams per litre anless otherwise noted)
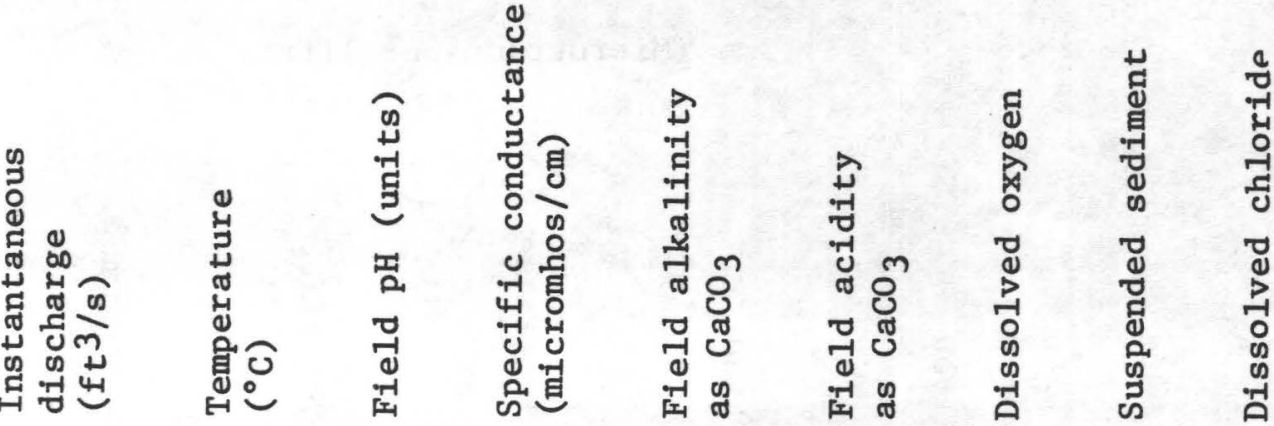

\section{3}

Sep. 05

1645

$\begin{array}{rr}6.3 & 29.0 \\ 10 & 12.5 \\ 25 & 4.5 \\ 113 & 1.5\end{array}$

$8.8 \quad 197$

62

7.8214

84

Nov. 07

0915

1535

Dec. 13

1035

1.5

8.5166

$6.6 \quad 132$

57

32

\section{4}

Jan. 09

Feb. 13

1450

Mar. 13

1400

Apr. 02

1445

$-\quad \quad 2.0$

$6.4 \quad 143$

39

$\begin{array}{lll}- & 13.89\end{array}$

$\begin{array}{rrrc}0 & 11.2 & 12 & 7.8 \\ -- & 10.1 & 6 & 10 \\ 0 & 13.0 & 4 & 7.0 \\ - & 13.6 & \text { E0 } & 2.5\end{array}$

May 01

1330

190

1.0

$7.6 \quad 129$

36

-- $\quad 13.8$

$7.4 \quad 109$

25

$-$

$473 \quad 4.5$

$7.6 \quad 123$

28

1345

1545

1400

1350

1415

1000

1330

$86 \quad 16.0$

$8.4 \quad 137$

37

$8.0 \quad 152$

$8.7 \quad 189$

8.6185

8.5192

8.1202

$7.2 \quad 176$

8.3113

52

64

69

69

73

41

24.0

$8.1 \quad 14.0$

57

394

8.0

39

$-$

13.7

12.8

10.

$\begin{array}{llll}- & 9.5 & 13 & 6.0\end{array}$

$\begin{array}{llll}0 & 9.2 & 1 & 6.4\end{array}$

$\begin{array}{llll}0 & 9.6 & 3 & 7.0\end{array}$

$\begin{array}{llll}0 & 9.3 & \text { EO } & 8.2\end{array}$

- $\quad 10.8$ E0 8.0

$\begin{array}{llll}1 & 12.8 & 3 & 9.0\end{array}$

$\begin{array}{llll}0 & 13.6 & 24 & 5.0\end{array}$

\section{5}

Jan. 14

Feb. 03

1350

$\begin{array}{rr}160 & .5 \\ -- & .5 \\ 78 & .5 \\ 76 & 7.0 \\ 100 & 16.0\end{array}$

6.3110

21

6.9124

13

$\begin{array}{ll}7.2 & 121\end{array}$

31

8.1114

34

8.9120

32

$\begin{array}{rrrr}4 & 14.2 & 4 & 5.0 \\ 1 & 13.0 & \text { E0 } & 5.0 \\ 20 & 13.0 & 3 & 5.5 \\ 1 & 12.0 & 1 & 6.0 \\ 0 & 10.2 & 6 & 3.5\end{array}$

E - Estimated. 
Table 6. --Water quality results for the Tioga River basin, September 1973 to May 1975--Continued.

01517500 MILL CREEK NEAR TIOGA, PA.

CHEMICAL ANALYSES

(Milligrams per litre unless otherwise noted)

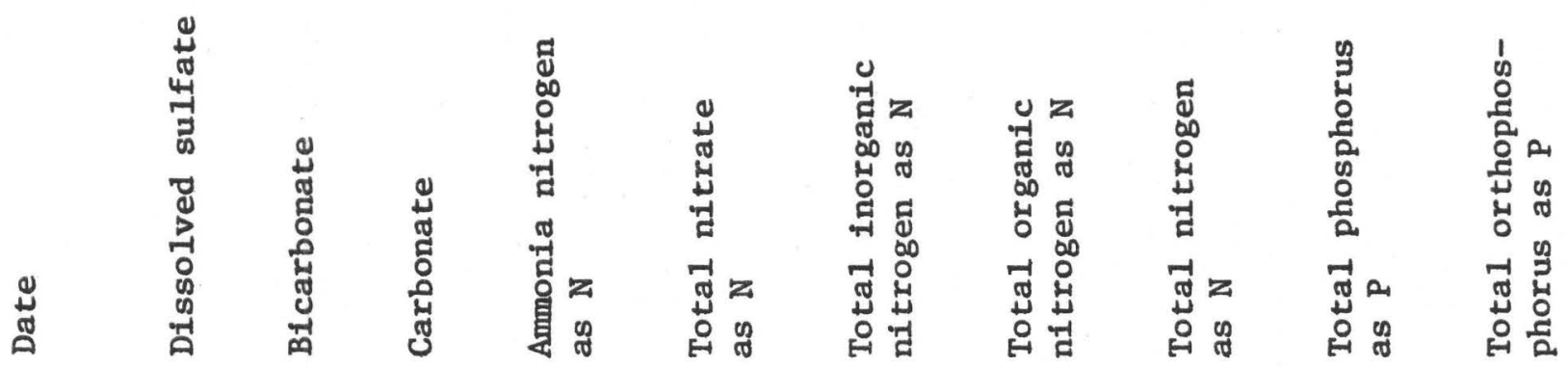

1973

$\begin{array}{lrrrrrrrrrr}\text { Sep. 05 } & 23 & 87 & 2 & .16 & .07 & .23 & .34 & .57 & .01 & .01 \\ \text { Oct. 11 } & 14 & 100 & 0 & .18 & .02 & .20 & .00 & .35 & .03 & .00 \\ \text { Nov. 07 } & 18 & 68 & 0 & .08 & .14 & .22 & .19 & .41 & .01 & .00 \\ \text { Dec. 13 } & 20 & 30 & 0 & .06 & .72 & .78 & .19 & .97 & .03 & .02 \\ \text { 1974 } & & & & & & & & & & \\ \text { Jan. 09 } & 20 & 47 & 0 & .09 & 1.0 & 1.1 & .28 & 1.4 & .01 & .01 \\ \text { Feb. 13 } & 17 & 44 & 0 & .02 & .70 & .72 & .24 & .96 & .01 & .01 \\ \text { Mar. 13 } & 8.2 & 30 & 0 & .06 & .45 & .51 & .21 & .72 & .02 & .01 \\ \text { Apr. 02 } & 19 & 31 & 0 & .02 & .70 & .72 & .35 & 1.1 & .08 & .02 \\ \text { May 01 } & 19 & 49 & 2 & .16 & .10 & .26 & .29 & .55 & .02 & .01 \\ \text { June 12 } & 15 & 69 & 0 & .11 & .54 & .65 & .31 & .92 & .04 & .01 \\ \text { Ju1y 17 } & 17 & 76 & 6 & .05 & .16 & .21 & .14 & .35 & .01 & .00 \\ \text { Aug. 14 } & 12 & 82 & 4 & .09 & .07 & .16 & .19 & .35 & .01 & .00 \\ \text { Sep. 12 } & 16 & 82 & 2 & .07 & .05 & .12 & .13 & .25 & .01 & .00 \\ \text { Oct. 10 } & 20 & 86 & 1 & .07 & .02 & .09 & .13 & .22 & .01 & .00 \\ \text { Nov. 07 } & 27 & 68 & 0 & .00 & .14 & .14 & .26 & .40 & .02 & .01 \\ \text { Dec. 09 } & 22 & 29 & 0 & .07 & 1.1 & 1.2 & .46 & 1.6 & .06 & .04 \\ \text { 1975 } & & & & & & & & & & \\ \text { Jan. 14 } & 21 & 26 & 0 & .02 & .90 & .92 & .26 & 1.2 & .03 & .02 \\ \text { Feb. 03 } & 21 & 37 & 0 & .02 & .68 & .70 & .30 & 1.0 & .02 & .01 \\ \text { Mar. 05 } & 20 & 36 & 0 & .01 & .95 & .96 & .26 & 1.2 & .02 & .01 \\ \text { Apr. 01 } & 19 & 35 & 0 & .00 & .50 & .50 & .16 & .66 & .01 & .01 \\ \text { May 14 } & 18 & 41 & 0 & .00 & .13 & .14 & .19 & .33 & .02 & .01\end{array}$


Table 6.--Water quality results for the Tioga River basin,

September 1973 to May 1975--Continued.

01518000 TIOGA RIVER AT TIOGA, PA.

CHEMICAL ANALYSES

(Milligrams per litre unless otherwise noted)

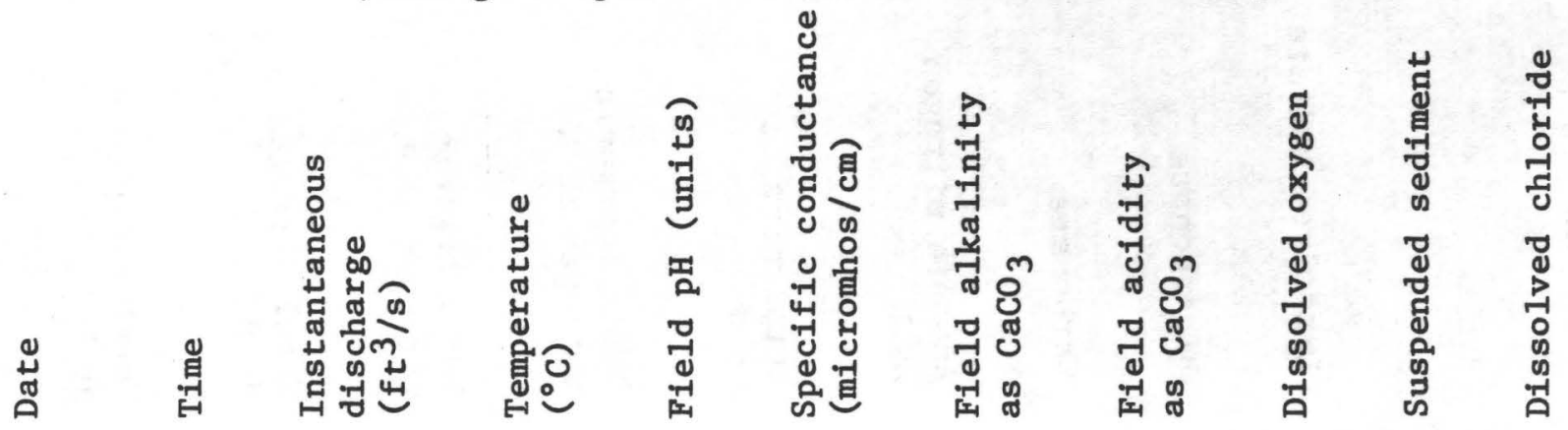

\section{3}

Sep. 06

Oct. 09

1000

Nov. 06

Dec. 11

1145

1415
1530

\section{4}

Jan. 08

Feb. 13

Mar. 13

Apr. 02

May 01

June 12

Ju1y 17

Aug. 14

Sep. 12

Oct. 10

Nov. 07

Dec. 09

\section{5}

1435

1600

1445

1445

1445

1515

1500

1445

1520

1050

1430

\section{7}

82

190

868

E230

E200

699

1780

413

133

65

35

30

48

194

1880

$$
\begin{array}{r}
22.0 \\
16.5 \\
4.0 \\
2.5
\end{array}
$$

$4.9 \quad 332$

$5.0 \quad 294$

5.3194

$5.7 \quad 145$

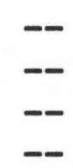

.0

$5.8 \quad 213$

$-$

5.7160

$5.5 \quad 152$

6.8141

6.7166

6.8181

$4.4 \quad 315$

$4.5 \quad 413$

$4.3 \quad 407$

$4.5 \quad 377$

6.7192

6.9105

2.0

785

284

E280

343

480

$\begin{array}{rrrr}.0 & 5.3 & 156 & 6 \\ .5 & 4.9 & 201 & 1 \\ 1.0 & 5.2 & 206 & 2 \\ 6.0 & 6.1 & 146 & 5 \\ 16.5 & 7.3 & 145 & 14\end{array}$

16.5

14

23

--

23

15

13

0

$-\overline{0}$

0

17
21

25

13

12

\section{2}

\section{2}

19

12

10

11

69

--

34

25

2

10

11

20

27

24

.2
9.493

$9.8-9$

$\begin{array}{ll}9.7 & 8.7\end{array}$

$\begin{array}{lll}12.9 & 29 & 3.0\end{array}$

$12.8 \quad 44 \quad 2.1$

May $14 \quad 143$

$11.4 \quad 14$

$13.6 \quad 13$

13.425

$12.6 \quad 113$

9.423

8.817

8.326

$7.7 \quad 6$

8.29

9.8 EO

$11.8 \quad 14$

13.8

65

6.3

6.0

5.0

7.0

7.6

5.0

7.6

9.0

11

9.5

8.0

3.5

E - Estimated. 
Table 6.--Water quality results for the Tioga River basin, September 1973 to May 1975--Continued.

01518000 TIOGA RIVER AT TIOGA, PA.

CHEMICAL ANALYSES

(Milligrams per litre unless otherwise noted)

岌
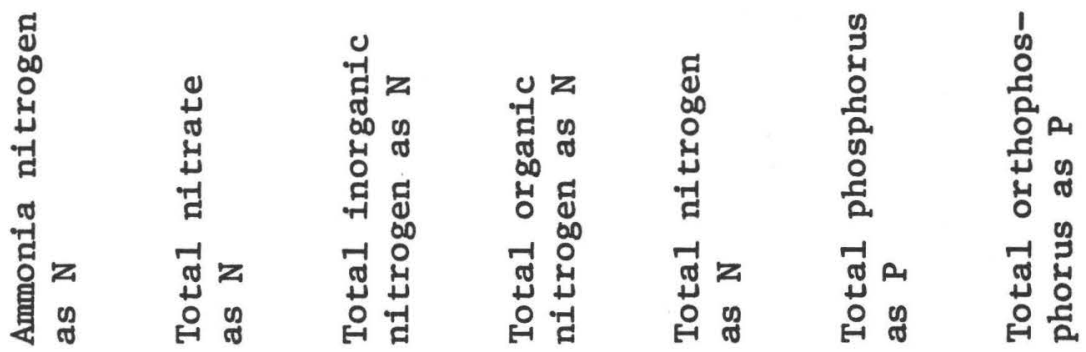

\section{3}

Sep. 06

0ct. 09

Nov. 06

Dec. 11

130

$$
116
$$

78

46

\section{4}

Jan. 08

Feb. 13

Mar. 13

Apr. 02

May 01

June 12

July 17

Aug. 14

Sep. 12

0ct. 10

Nov. 07

Dec. 09$$
73
$$

64

44

29

49

59

127

188

117

160

63

27

$\begin{array}{ll}2 & 0 \\ 3 & 0\end{array}$

.15

.13

.12

.03
.09

.17

.06

.15

.22

.16

.05

.08

$$
\begin{array}{r}
.70 \\
.80
\end{array}
$$

$.05 \quad .81$

$.08 \quad .61$

.03

.02

.01
.80

.90

.40

.52

.23

.32

.43

.23

.18

.86

$\begin{array}{ll}.88 & .69 \\ .19 & .18 \\ .41 & .18 \\ .74 & .23\end{array}$

1.6

.37

.59

.97

.85

.93

.73

.93

.49

.69

.29

.47

.65

.39

.23

.94

.18
.26
.19
.15
.23
.39
.16
.15
.09
.13
.22
.36

1.0

1.2

.92

1.1

.72

1.1

.45

.62

.74

.52

.45

1.3

.86

.69

.17

.22

$.93 \quad .10$

$.95 \quad .20$

$.31 \quad .15$
1.0

.91

1.0

1.2

.46
.03

.01

.05

.15

.05

.03

.04

.01

.01

.03

.03

.06

.04

.02

.04

.02

.04
.06 .02 .02 .05

.93

.29
.01
.01
.01
.05
.02
.01
.02
.01
.00
.02
.02
.04


Table 6.- $-\frac{\text { Water quality results for the Tioga River basin, }}{\text { September } 1973 \text { to May 1975--Continued. }}$

01518000 TIOGA RIVER AT TIOGA, PA.

CHEMICAL ANALYSES

(Micrograms per litre)

$\stackrel{\mathscr{\pi}}{\stackrel{\pi}{a}}$

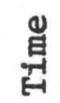

塄

芑

貝真夏

링

मे

Dissolved

1974

Feb. 13

Mar. 13

Apr. 02

1975

Mar. 05

Apr. 01

May 14

1435

1600

1445

1415

1345

1400

40

1430

40

10

$\begin{array}{rr}1 & 0 \\ 0 & <10\end{array}$

31

19

10

0

Tota1

\section{4}

May 01

June 12

July 17

Aug. 14

Sep. 12

Oct. 10

Nov. 07

Dec. 09

9

0

\section{5}

Jan. 14

Feb. 03

\section{5}

1445

1515

1500

1445

1520

1050

1500

10

5900

4400

7400

4900

960

$1430 \quad 1600$

1
2
0
0
1
$<1$
0
1

1
1

0
0

10

28

38
20

10

50

30

40

20

0

0

20

20 


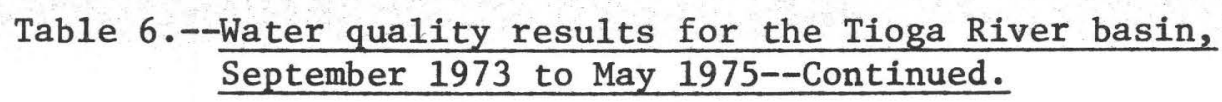

01518000 TIOGA RIVER AT TIOGA, PA.

CHEMICAL ANALYSES

(Micrograms per litre)

$\stackrel{\stackrel{\varpi}{\pi}}{\stackrel{0}{0}}$

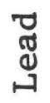

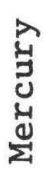

圆

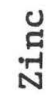

Dissolved

1974

Feb. 13

Mar. 13

Apr. 02

70

900

80

1975

Mar. 05

Apr. 01

May 14

470

170

40

1600

1300

$<.5$

$<.5$

0

崩

$0 \quad 810$

$<.5$

1

0

160

Tota1

\section{4}

May 01

June 12

July 17

Aug. 14

Sep. 12

Oct. 10

Nov. 07

Dec. 09

1975

Jan. 14

Feb. 03

2200

1800
1700

790

380

150

310

720

770

2600
21200

$4 \quad 1700$

$3 \quad 5900$

$4 \quad 5200$

$5 \quad 5700$

$2 \quad 4800$

$0 \quad 1100$

$4 \quad 450$

$1 \quad 1400$

22300
$<.5$

$<.5$

$<.5$

$<.5$

$<.5$

$<.5$

$<.5$

$<.5$

$<.5$

$<.5$

0
1
$<1$
$<2$
2
$<2$
0
0

0

2
140

210

3100

710

900

750

190

60

140

300 
Table 6.--Water quality results for the Tioga River basin, September 1973 to May 1975--Continued.

01518400 CROOKED CREEK AT MIDDLEBURY CENTER, PA.

CHEMICAL ANALYSES

(Milligrams per litre unless otherwise noted)

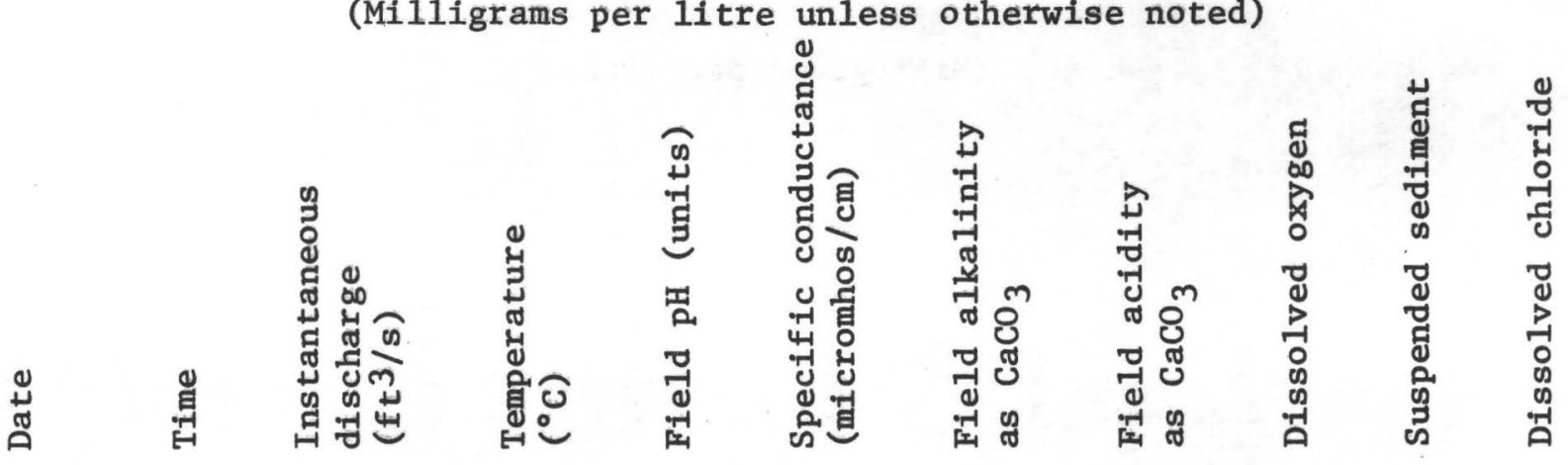

1973

\begin{tabular}{|c|c|c|c|c|c|c|c|c|c|c|}
\hline Sep. 05 & 0915 & 24 & 22.5 & 7.5 & 206 & 61 & - & 11.4 & 8 & 8.9 \\
\hline Oct. 10 & 0930 & 16 & 14.5 & 7.2 & 225 & 68 & - & 9.8 & 14 & 12 \\
\hline Nov. 07 & 0820 & 39 & 3.5 & 7.2 & 179 & 59 & - & 12.2 & 3 & 8.0 \\
\hline Dec. 12 & 0845 & 146 & 2.0 & 7.1 & 141 & 39 & - & 13.0 & E0 & 2.5 \\
\hline \multicolumn{11}{|l|}{1974} \\
\hline Jan. 09 & 1545 & - & .0 & 6.2 & 165 & 47 & - & 13.8 & 6 & 6.2 \\
\hline Feb. 14 & 1715 & - & .5 & 6.6 & 145 & 41 & - & 14.5 & 4 & 7.0 \\
\hline Mar. 15 & 0900 & 69 & .5 & 7.4 & 130 & 25 & - & 13.4 & E0 & 5.5 \\
\hline Apr. 04 & 0915 & 453 & 9.5 & 7.2 & 93 & 18 & - & 10.8 & 68 & 3.0 \\
\hline May 03 & 0915 & 50 & 9.5 & 7.2 & 151 & 48 & 6 & 10.9 & 1 & 5.5 \\
\hline June 14 & 0845 & 8.0 & 14.0 & 7.3 & 185 & 69 & 9 & - & 6 & 7.5 \\
\hline July 18 & 1525 & 6.9 & 25.0 & 8.5 & 190 & 63 & 0 & 9.4 & EO & 7.4 \\
\hline Aug. 16 & 0830 & 3.3 & 18.0 & 7.5 & 221 & 73 & -- & 7.0 & 6 & 9.0 \\
\hline
\end{tabular}


Table 6.--Water quality results for the Tioga River basin, September 1973 to May 1975--Continued.

01518400 CROOKED CREEK AT MIDDLEBURY CENTER, PA.

CHEMICAL ANALYSES

(Milligrams per 1itre unless otherwise noted)

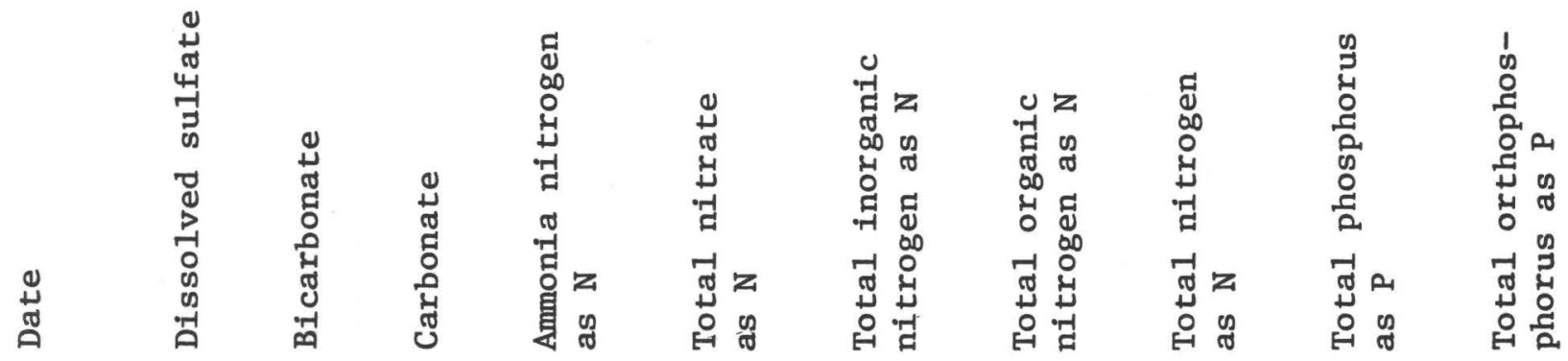

1973

\begin{tabular}{|c|c|c|c|c|c|c|c|c|c|c|}
\hline Sep. 05 & 17 & 89 & 0 & .22 & .29 & .51 & .32 & .83 & .04 & .02 \\
\hline Oct. 10 & 15 & 105 & 0 & .05 & .14 & .19 & .12 & .31 & .03 & .01 \\
\hline Nov. 07 & 20 & 74 & 0 & .06 & .29 & .35 & .18 & .53 & .02 & .02 \\
\hline Dec. 12 & 24 & 44 & 0 & .09 & .68 & .77 & .18 & .95 & .11 & .08 \\
\hline \multicolumn{11}{|l|}{1974} \\
\hline Jan. 09 & 22 & 55 & 0 & .07 & 1.2 & 1.3 & .28 & 1.6 & .02 & .01 \\
\hline Feb. 14 & 18 & 50 & 0 & .07 & .90 & .97 & .30 & 1.3 & .03 & .01 \\
\hline Mar. 15 & 14 & 38 & 0 & .05 & .70 & .75 & .18 & .93 & .01 & .01 \\
\hline Apr. 04 & 17 & 25 & 0 & .03 & .50 & .53 & .50 & 1.0 & .09 & .04 \\
\hline May 03 & 20 & 57 & 0 & .11 & .20 & .31 & .20 & .51 & .02 & .01 \\
\hline June 14 & 19 & 84 & 0 & .23 & .50 & .73 & .22 & .95 & .36 & .35 \\
\hline July 18 & 24 & 76 & 4 & .13 & .14 & .27 & .19 & .46 & .03 & .01 \\
\hline Aug. 16 & 17 & 92 & 0 & .13 & .11 & .24 & .23 & .47 & .08 & .06 \\
\hline
\end{tabular}


Table 6.--Water quality results for the Tioga River basin,

September 1973 to May 1975--Continued.

01518500 CROOKED CREEK AT TIOGA, PA.

\section{CHEMICAL ANALYSES}

(Milligrams per litre unless otherwise noted)
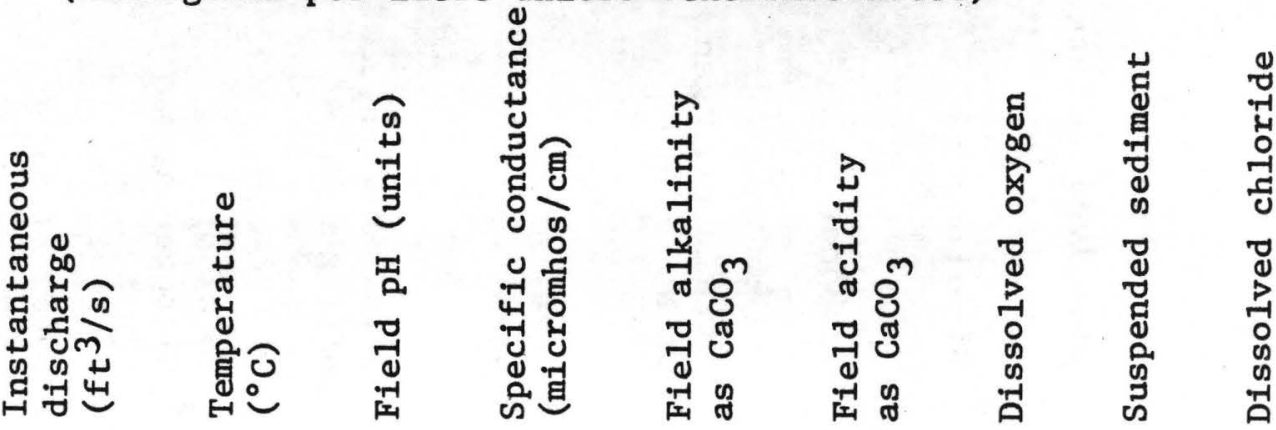

1973

\begin{tabular}{|c|c|c|c|c|c|c|c|c|c|c|}
\hline Sep. 05 & 1045 & 47 & 23.5 & 7.0 & 184 & 50 & - & 8.2 & 64 & 7.0 \\
\hline Oct. 09 & 1615 & 35 & 16.5 & 6.9 & 197 & 70 & -- & 9.3 & 9 & 10 \\
\hline Nov. 06 & 1300 & 61 & 5.0 & 7.9 & 153 & 55 & -- & 11.6 & 56 & 5.0 \\
\hline Dec. 11 & 1300 & 292 & 2.5 & 6.8 & 134 & 36 & -- & 12.6 & 18 & 1.9 \\
\hline \multicolumn{11}{|l|}{1974} \\
\hline Jan. 08 & 1225 & E66 & .0 & 6.9 & 146 & 41 & -- & 13.0 & 7 & 4.5 \\
\hline Feb. 13 & 1710 & E68 & 2.0 & 6.4 & 132 & 36 & -- & 13.2 & EO & 5.0 \\
\hline Mar. 13 & 1800 & 89 & 2.5 & 7.1 & 111 & 25 & -- & 13.6 & 24 & 3.5 \\
\hline Apr. 02 & 1625 & 811 & 6.0 & 7.8 & 117 & 29 & -- & 12.4 & 289 & 4.0 \\
\hline May 01 & 1545 & 132 & 16.0 & 7.6 & 144 & 43 & -- & 10.8 & 10 & 4.0 \\
\hline June 12 & 1550 & 26 & 19.5 & 7.5 & 168 & 62 & 12 & 8.7 & 17 & 5.0 \\
\hline July 17 & 1415 & 18 & 23.0 & 7.7 & 190 & 66 & -- & 8.6 & E0 & 5.8 \\
\hline Aug. 14 & 1550 & 11 & 27.0 & 8.2 & 197 & 78 & -- & 8.2 & 30 & 7.0 \\
\hline Sep. 12 & 1620 & 10 & 24.0 & 7.8 & 205 & 78 & -- & 8.6 & 16 & 8.0 \\
\hline Oct. 10 & 1630 & 10 & 15.0 & 7.5 & 221 & 83 & 4 & 11.6 & 18 & 8.5 \\
\hline Nov. 07 & 1145 & 64 & 8.0 & 7.2 & 185 & 54 & 3 & 11.4 & 54 & 10 \\
\hline Dec. 09 & 1515 & 513 & 2.0 & 7.7 & 128 & 45 & 4 & 13.8 & 50 & 5.0 \\
\hline \multicolumn{11}{|l|}{1975} \\
\hline Jan. 14 & 1545 & 331 & .0 & 6.8 & 114 & 27 & 3 & 14.8 & 19 & 4.0 \\
\hline Feb. 03 & 1545 & -- & .5 & 6.9 & 135 & 31 & 5 & 14.0 & EO & 5.5 \\
\hline Mar. 05 & 1515 & 131 & 1.0 & 7.2 & 132 & 35 & 4 & 13.0 & 10 & 5.0 \\
\hline
\end{tabular}

E - Estimated. 

Table 6.--Water quality results for the Tioga River basin,

01518500 CROOKED CREEK AT TIOGA, PA.

CHEMICAL ANALYSES

(Milligrams per litre unless otherwise noted)

$+$

ป્
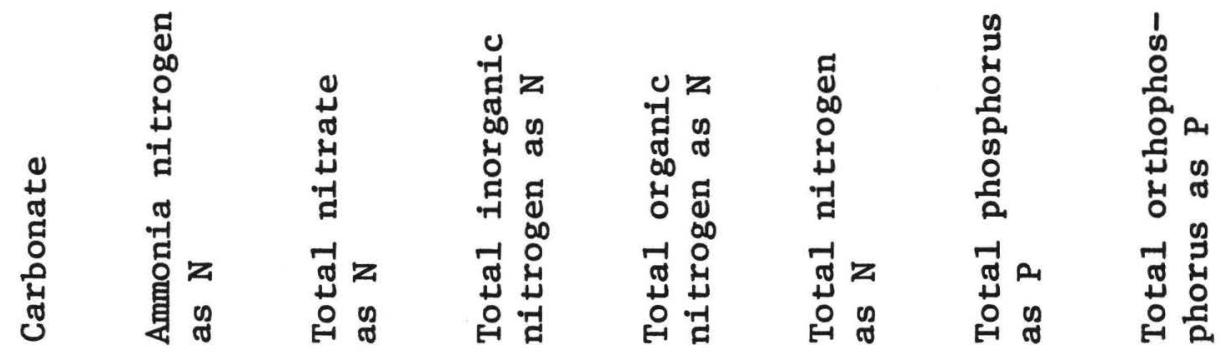

\title{
1973
}

Sep. 05

0ct. 09

$22 \quad 73$

.11

$15 \quad 89$

0

$$
.09
$$

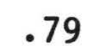

.06

.05

.27

.90

.33

.33

.31

.50

.57

.22

$$
.09
$$

$$
.05
$$

.70

$.07 \quad .32$

$.12 \quad .80$

$.10 \quad .20$

$.09 \quad .41$

$.09 \quad .05$

$.09 \quad .02$

$.07 \quad .07$

$.09 \quad .14$

$$
.79 \quad .22
$$

$.75 \quad .19$

$.39 \quad .18$

$.92 \quad .66$

$.30 \quad .24$

$.50 \quad .30$

$.14 \quad .21$

$.11 \quad .24$

$.14 \quad .16$

$.23 \quad .17$

$.08 \quad 1.2$

1.3

.51

1.0

.94

.57

1.6

.54

.80

.35

.35

.30

.40

.14

.18

.17

.10

.11

.07

Nov. 07

$28 \quad 67$

Dec. 09

$22 \quad 48$

1975

Jan. 14

Feb. 03

$20 \quad 32$

0
0
0

.04

.57

.03

.01

$\begin{array}{ll}.61 & .29 \\ .69 & .31 \\ .89 & .25\end{array}$

.29
.31
.25

.66
.88

.90
1.0
1.1

.03

.02

.00

.01

.10

.02

.02

.02

.03

.07

.04

.07

.03

1.8

.08

.05

.08

$20 \quad 40$

0

.0

\begin{abstract}
.
\end{abstract}


Table 6.--Water quality results for the Tioga River basin, September 1973 to May 1975--Continued.

01518500 CROOKED CREEK AT TIOGA, PA.

CHEMICAL ANALYSES

(Micrograms per litre)

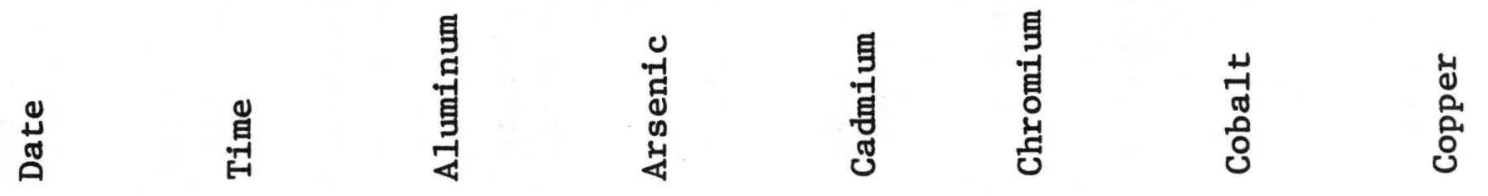

Total

1974

0ct. 10

1630

450

$<1$

1

0

3

0

01518550 CROOKED CREEK AT TIOGA, PA.

(Milligrams per litre unless otherwise noted)

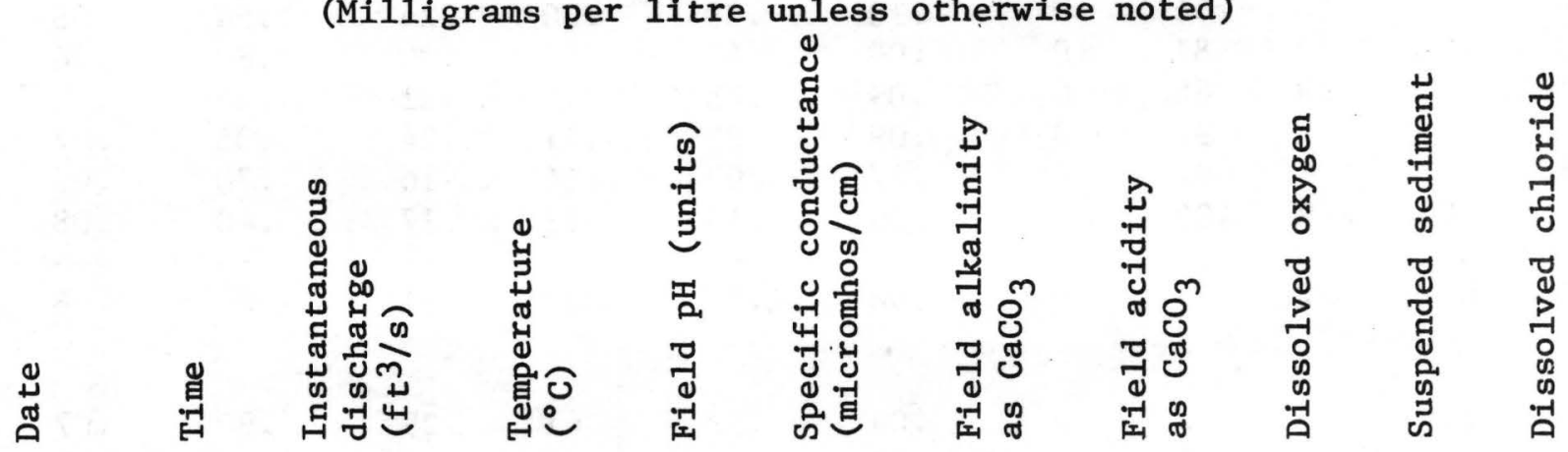

1975

Apr. 01

1445

125

5.5

$7.4 \quad 117$

30

$\begin{array}{lll}7 & 11.8 & 192\end{array}$

4.5

May $14 \quad 1530$

181

15.0

$7.9 \quad 136$

42

$\begin{array}{lll}1 & 10.0 \quad 931\end{array}$

3.5 
Table 6.--Water quality results for the Tioga River basin, September 1973 to May 1975--Continued.

01518500 CROOKED CREEK AT TIOGA, PA.

CHEMICAL ANALYSES

(Micrograms per litre)

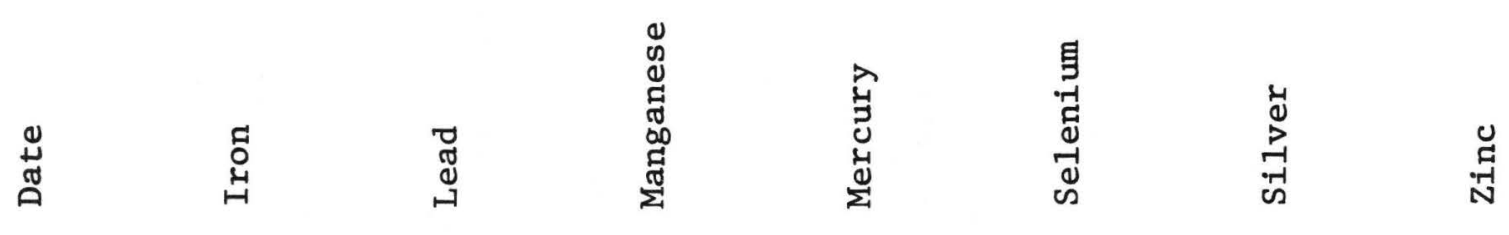

$\underline{\text { Total }}$

1974

oct. 10

1300

2

130

$<.5$

2

40

01518550 CROOKED CREEK AT TIOGA, PA.

(Milligrams per litre unless otherwise noted)

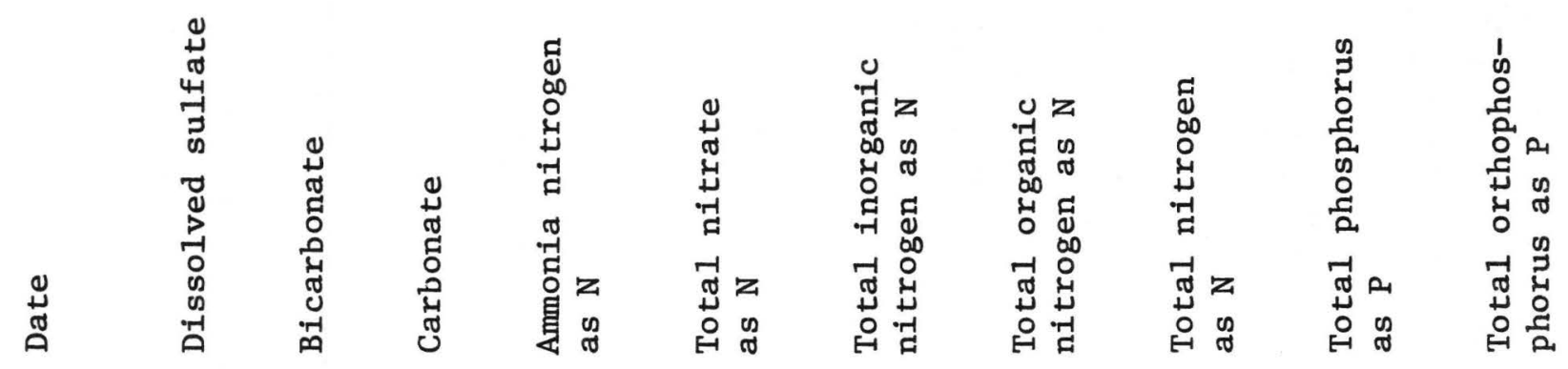

1975

Apr. 01

19

$\begin{array}{ll}19 & 41 \\ 17 & 46\end{array}$

.02

.50

$.52 \quad .28$

.80

.16

.11

May 14

$\begin{array}{ll}41 & 0 \\ & \end{array}$

.19

$.26 \quad .47$

.73

.61

.02 
Table 6.--Water quality results for the Tioga River basin, September 1973 to May 1975--Continued.

01518700 TIOGA RIVER AT TIOGA JUNCTION, PA.

\section{CHEMICAL ANALYSES}

(Milligrams per litre unless otherwise noted)
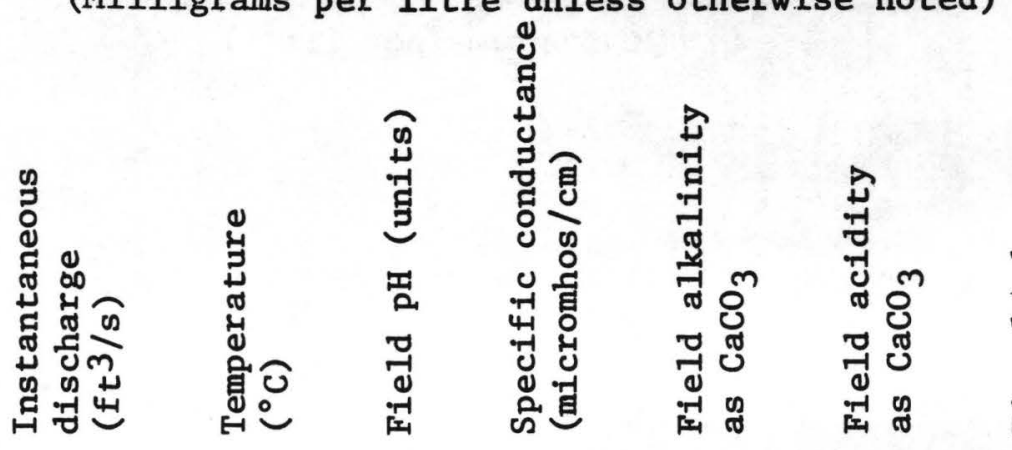

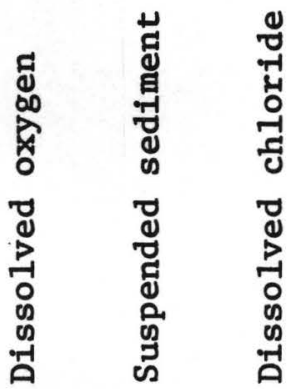

1973

Sep. 05

Oct. 09

Nov. 06

Dec. 11

$\begin{array}{rr}1540 & 75 \\ 1700 & 131 \\ 1350 & 281 \\ 1500 & 1300\end{array}$

27.0
16.5
5.0
2.5

6.4276

$7.2 \quad 252$

11

$6.8 \quad 185$

16

$-10.2 \quad 16$

9.1

$7.0 \quad 139$

14
15

$\begin{array}{lll}- & 9.8 & 16\end{array}$

9.1

$\begin{array}{llll}-- & 12.1 & 21 & 5.0\end{array}$

\section{4}

Jan. 08

$1335 \quad$ E332

.0
1.5
2.0
7.0

5.9194

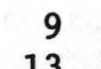

$-13.8$

7.2165

Mar. 13

883

6.5133

2900

7.6120

610

16.5

6.9160

6.9171

93

20.0

6.6255

22.0

7.0323

-- $\quad 12.4 \quad 41$

2.1

July 17

1300

52

27.0

0900

45

21.5

6.4328

10.0

$6.5 \quad 329$

289

8.0

7.0194

$-$

13.

-- 12.

-- 9.8

10

9.

19

48

14

10

10

2.0

7.2108

34

21

--

8.0

6

$$
9.0
$$

10.

3

3

$$
13.2
$$

12 .

$\begin{array}{rrr}5.9 & 142 & 12 \\ 5.6 & 161 & 8 \\ 6.6 & 172 & 9 \\ 7.4 & 133 & 16 \\ 7.8 & 146 & 22\end{array}$

7
6
11
7
2

15.6

18

$\begin{array}{ll}13.6 & \text { EO } \\ 12.8 & 52\end{array}$

12.017

17

9.666

4.5

5.0

5.0

5.5

May $14 \quad 1645$

740

17.0

E - Estimated 
Table 6.--Water quality results for the Tioga River basin, September 1973 to May 1975--Continued.

01518700 TIOGA RIVER AT TIOGA JUNCTION, PA.

CHEMICAL ANALYSES

(Milligrams per litre unless otherwise noted)

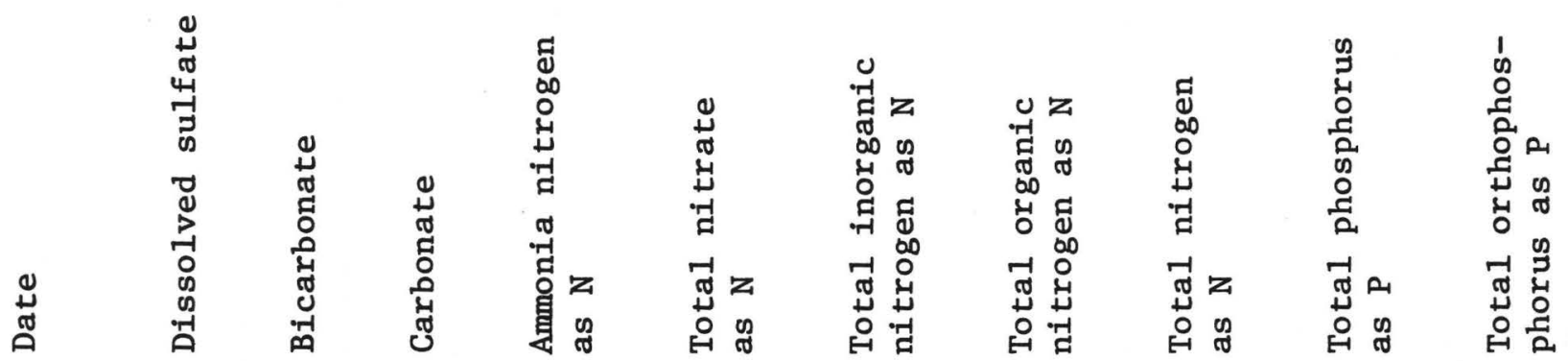

1973

$\begin{array}{lrrrrrrrrrr}\text { Sep. 05 } & 29 & 18 & 0 & .12 & .41 & .53 & .13 & .66 & .08 & .02 \\ \text { Oct. 09 } & 82 & 19 & 0 & .07 & .18 & .25 & .25 & .50 & .06 & .02 \\ \text { Nov. 06 } & 63 & 13 & 0 & .11 & .34 & .45 & .31 & .76 & .06 & .02 \\ \text { Dec. 11 } & 40 & 18 & 0 & .05 & .63 & .68 & .27 & .95 & .17 & .09 \\ \text { 1974 } & & & & & & & & & & \\ \text { Jan. 08 } & 40 & 10 & 0 & .12 & .90 & 1.0 & .17 & 1.2 & .03 & .01 \\ \text { Feb. 13 } & 49 & 16 & 0 & .11 & .70 & .81 & .23 & 1.0 & .03 & .02 \\ \text { Mar. 13 } & 35 & 9 & 0 & .09 & .45 & .54 & .16 & .70 & .02 & .01 \\ \text { Apr. 02 } & 25 & 24 & 0 & .14 & 1.5 & 1.6 & 1.3 & 2.9 & .49 & .33 \\ \text { May 01 } & 45 & 26 & 0 & .24 & .40 & .64 & .29 & .93 & .06 & .03 \\ \text { June 12 } & 51 & 24 & 0 & .08 & .61 & .69 & .21 & .90 & .02 & .01 \\ \text { Ju1y 17 } & 87 & 24 & 0 & .15 & .23 & .38 & .12 & .50 & .01 & .00 \\ \text { Aug. 14 } & 123 & 16 & 0 & .11 & .16 & .27 & .16 & .43 & .01 & .00 \\ \text { Sep. 13 } & 118 & 10 & 0 & .09 & .34 & .43 & .05 & .48 & .01 & .00 \\ \text { Oct. 11 } & 132 & 10 & 0 & .14 & .23 & .37 & .13 & .50 & .01 & .00 \\ \text { Nov. 07 } & 53 & 40 & 0 & .03 & .27 & .30 & .27 & .57 & .05 & .03 \\ \text { Dec. 09 } & 27 & 23 & 0 & .08 & .81 & .89 & .56 & 1.4 & .15 & .09 \\ \text { 1975 } & & & & & & & & & & \\ \text { Jan. 14 } & 51 & 8 & 0 & .05 & .63 & .68 & .24 & .92 & .03 & .02 \\ \text { Feb. 03 } & 63 & 10 & 0 & .09 & .75 & .84 & .37 & 1.2 & .05 & .03 \\ \text { Mar. 05 } & 64 & 10 & 0 & .02 & .99 & 1.0 & .25 & 1.3 & .05 & .04 \\ \text { Apr. 01 } & 42 & 15 & 0 & .01 & .66 & .67 & .20 & .87 & .03 & .02 \\ \text { May 14 } & 35 & 26 & 0 & .01 & .27 & .29 & .19 & .48 & .08 & .02\end{array}$


Table 6.--Water quality results for the Tioga River basin, September 1973 to May 1975--Continued.

01518700 TIOGA RIVER AT TIOGA JUNCTION, PA.

CHEMICAL ANALYSES

(Micrograms per litre)
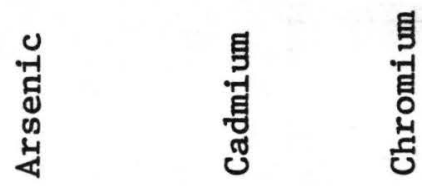

\section{Dissolved}

1974

Feb. 13

Mar. 13

1620

Apr. 02

1715

1545

1975

Mar. 05

Apr. 01

1615

1545

70

1645

30

70

0
0
2

$\begin{array}{rr}1 & 0 \\ 0 & 0 \\ 0 & <10\end{array}$

18

10

May 14

11

0

\section{Total}

\section{4}

May 01

June 12

July 17

Aug. 14

Sep. 13

Oct. 11

Nov. 07

1650

1730

2600

2

0

13

20

1300

1645

0900

0915

1300

0
150

1

$<1$

70

190

1700

960

1645

2300

$1700 \quad 1500$

1800

1
2

0

23

0

0

16

10

20

$34 \quad 0$

$75 \quad 10$

$55 \quad 10$

$13 \quad 10$

810 
Table 6.--Water quality results for the Tioga River basin, September 1973 to May 1975--Continued.

01518700 TIOGA RIVER AT TIOGA JUNCTION, PA.

CHEMICAL ANALYSES

(Micrograms per 1itre)

$\underset{⿱ ⺌ 兀}{\stackrel{0}{0}}$

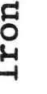

త్త

ญु
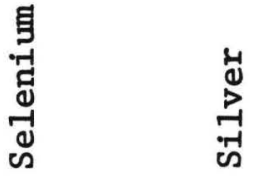

\section{Dissolved}

\section{4}

Feb. 13

Mar. 13

Apr. 02

0
60
110

1975

Mar. 05

Apr. 01

May 14

170

70

40

1
0
1

1300
930
530

$<.5$

$<.5$

1.3

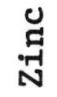

--
--
--
170
100
30

\section{Tota1}

\section{4}

May 01

June 12

July 17

Aug. 14

Sep. 13

0ct. 11

Nov. 07

Dec. 09

3500

330

40

20

120

40

1100

4500

1975

Jan. 14

Feb. 03

1400

1300

$\begin{array}{rr}14 & 930 \\ 2 & 1200 \\ 0 & 1300 \\ 1 & 3000 \\ 2 & 3900 \\ 3 & 5700 \\ 2 & 770 \\ 5 & 470\end{array}$

$<.5$
$<.5$
$<.5$
$<.5$
$<.5$
$<.5$
$<.5$
$<.5$
0
1
0
$<2$
2
0
0

$<.5$
$<.5$
1400

$\begin{array}{ll}2 & 1000 \\ 4 & 1400\end{array}$

0
0

90

180 
Table 6.--Water quality results for the Tioga River basin,

01518850 COWANESQUE RIVER AT WESTFIELD, PA.

CHEMICAL ANALYSES

(Milligrams per litre unless otherwise noted)

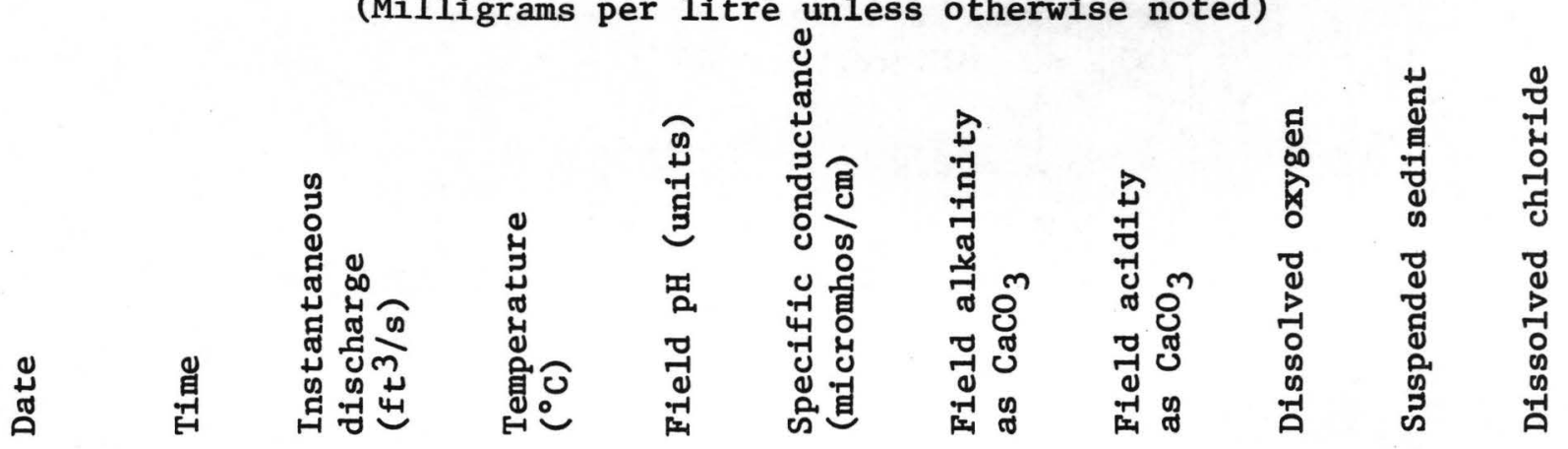

1973

Sep. $04 \quad 1330$

oct. $10 \quad 1625$

Nov. $07 \quad 1000$

6.827 .0

6.9204

$7.7 \quad 17.5$

8.5162

48

28

7.3130

63

4.0

6.9114

35

35

Dec. 121045

1.5

25

$\begin{array}{ll}6.4 & 113 \\ 6.9 & 109\end{array}$

- $\quad .0$

23

$6.8 \quad 95$

25

$77 \quad .5$

$272 \quad 2.5$

$6.4 \quad 88$

17

$51 \quad 7.5$

$7.4 \quad 107$

14

$8.0 \quad 14.5$

$7.4 \quad 138$

28

$7.4 \quad 19.0$

7.4143

46

3.118 .0

7.5154

46

59

\begin{tabular}{rrrl}
-- & 11.0 & 16 & \multicolumn{1}{l}{19} \\
0 & 10.3 & 2 & 10 \\
-- & 11.9 & 1 & 5.0 \\
-- & 13.4 & E0 & 2.0
\end{tabular}

Aug. 15

0930

E - Estimated. 
Table 6.--Water quality results for the Tioga River basin, September 1973 to May 1975--Continued.

01518850 COWANESQUE RIVER AT WESTFIELD, PA.

\section{CHEMICAL ANALYSES}

(Milligrams per litre unless otherwise noted)

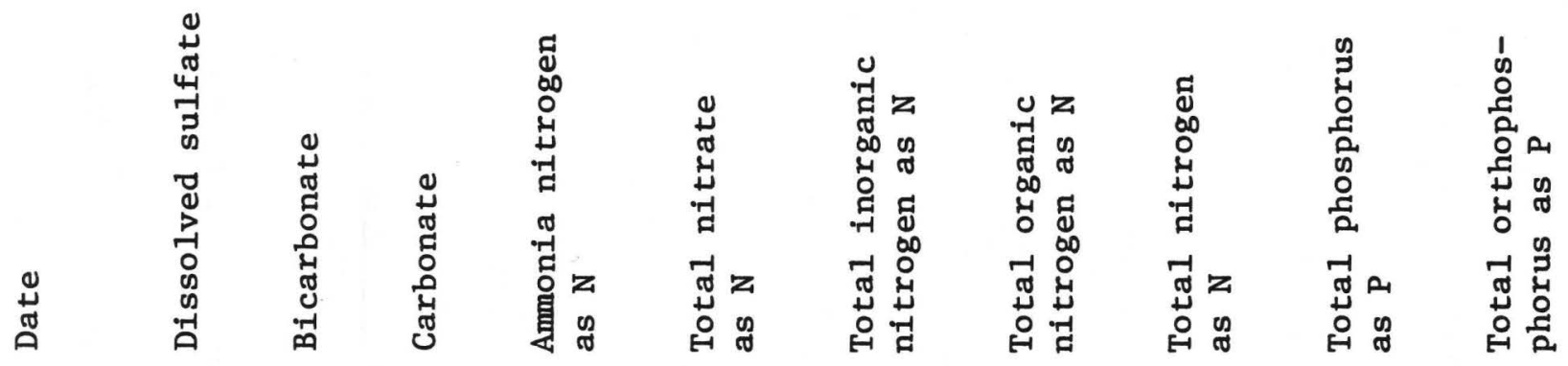

1973

$\begin{array}{ccccccccccc}\text { Sep. 04 } & 23 & 71 & 0 & .21 & .18 & .39 & .32 & .71 & .06 & .04 \\ \text { Oct. 10 } & 14 & 68 & 2 & .03 & .07 & .10 & .19 & .29 & .02 & .01 \\ \text { Nov. 07 } & 18 & 43 & 0 & .06 & .43 & .49 & .24 & .73 & .01 & .01 \\ \text { Dec. 12 } & 18 & 31 & 0 & .08 & .48 & .56 & .19 & .75 & .01 & .01 \\ \text { 1974 } & & & & & & & & & & \\ \text { Jan. 09 } & 16 & 31 & 0 & .10 & .70 & .80 & .20 & 1.0 & .01 & .01 \\ \text { Feb. 14 } & 16 & 30 & 0 & .04 & .80 & .84 & .36 & 1.2 & .01 & .01 \\ \text { Mar. 14 } & 14 & 24 & 0 & .05 & .45 & .50 & .23 & .73 & .01 & .01 \\ \text { Apr. 03 } & 17 & 18 & 0 & .03 & 1.0 & 1.0 & .23 & 1.3 & .05 & .04 \\ \text { May 02 } & 18 & 37 & 0 & .12 & .10 & .22 & .19 & .71 & .02 & .00 \\ \text { June 13 } & 12 & 60 & 0 & .04 & .63 & .67 & .18 & .85 & .01 & .00 \\ \text { July 18 } & 15 & 56 & 0 & .07 & .09 & .16 & .22 & .38 & .01 & .00 \\ \text { Aug. 15 } & 13 & 70 & 0 & .13 & .05 & .18 & .19 & .37 & .01 & .00\end{array}$


Table 6.--Water quality results for the Tioga River basin, September 1973 to May 1975--Continued.

01518860 MILL CREEK AT WESTFIELD, PA.

CHEMICAL ANALYSES

(Milligrams per litre unless otherwise noted)
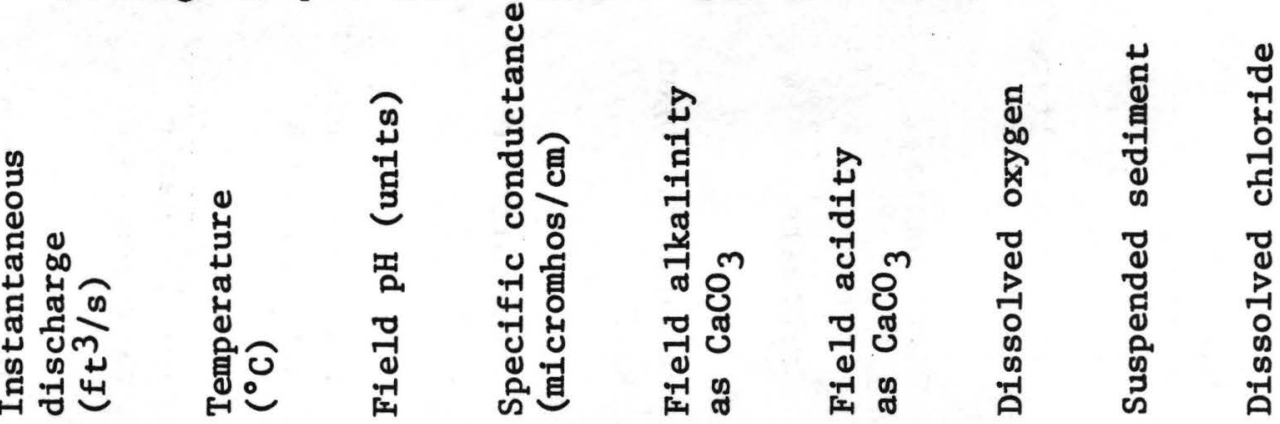

1973

Sep. 04

Oct. 10

Nov. 07

Dec. 12

1445

1540

1045

1150

$5.0 \quad 29.0$

$4.2 \quad 17.5$

$8.7 \quad 234$

9.4213

9.5

7.5173

$6.7 \quad 170$

65

72

52

44

2.5

$\begin{array}{ll}-- & .5\end{array}$

$\begin{array}{ll}-- & .5\end{array}$

$23 \quad .5$

$59 \quad 3.0$

9.59 .0

$1.2 \quad 15.5$

$2.0 \quad 20.0$

$2.0 \quad 19.0$
$6.3 \quad 226$

$6.2 \quad 177$

$\begin{array}{ll}7.3 & 147\end{array}$

6.5129

8.5198

$8.2 \quad 368$

8.6254

8.5275
Aug. $15 \quad 1030$
51

49

35

30

56

107

75

83 $\begin{array}{lll}0 & 11.2 & 10\end{array}$

$\begin{array}{llll}0 & 11.0 & 26 & 14\end{array}$

$\begin{array}{llll}-- & 12.0 & 10 & 10\end{array}$

-- 13.2 E0 10

E - Estimated. 
Table 6.--Water quality results for the Tioga River basin, September 1973 to May 1975--Continued.

01518860 MILL CREEK AT WESTFIELD, PA.

CHEMICAL ANALYSES

(Milligrams per litre unless otherwise noted)

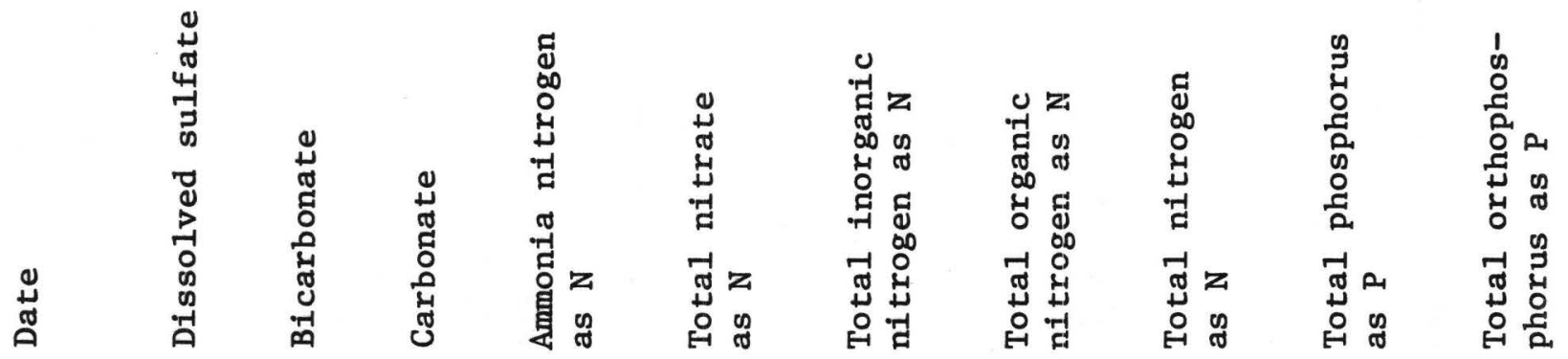

1973

Sep. 04

Oct. 10

Nov. 07

$27 \quad 83$

834

\section{4}

.21

.20

.41

.44

$.12 \quad .25$

.03

.09

.50

.31 .

$.71 \quad .38$

.61

.85
.37
.81
1.1

.11

.03

.08

.05

.09

.02

.06

.04

\section{4}

Jan. 09

Feb. 14

\section{2}

Mar. 14

Apr. 03

May 02

June 13

July 18

Aug. 15

$\begin{array}{rrr}24 & 63 & 0 \\ 21 & 59 & 0 \\ 17 & 44 & 0 \\ 20 & 34 & 0 \\ 25 & 69 & 3 \\ 32 & 124 & 6 \\ 20 & 91 & 9 \\ 19 & 88 & 9\end{array}$

.27

.23

.80

.80

1. 1

1.0

.33

.17

.77

.94

.48

.09

1.0

.23

.17

.13

.21
.30

1.0

.50

.63
1.1

.94

1. 2

.63

.84
. 36

.41

.39

.34

.40

.42
1.4

1.5

1.3

1.5

.92

1.5

1.0

1.3
.06

.12

.10

.14

.12

.19

.09

.09
.06

.10

.06

.05

.08

.18

.07

.07 
Table 6.--Water quality results for the Tioga River basin,

September 1973 to May 1975--Continued.

01518870 COWANESQUE RIVER AT COWANESQUE, PA.

CHEMICAL ANALYSES

(Milligrams per litre unless otherwise noted)

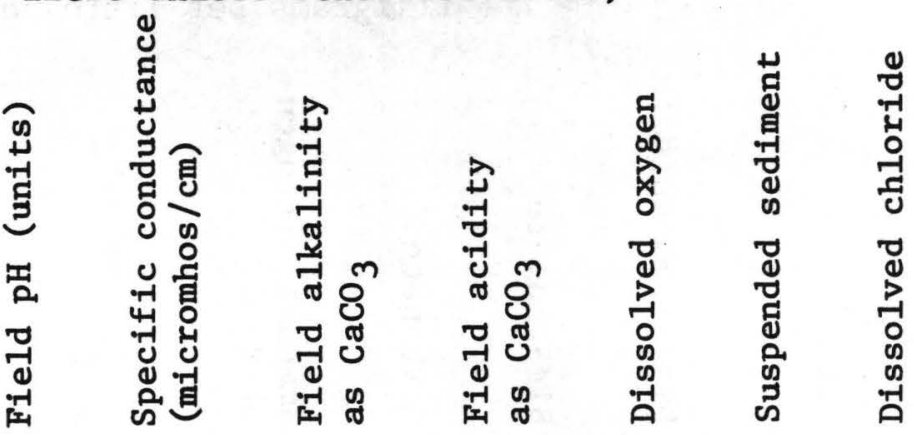

$\begin{array}{lrrrrrrrrrr}1973 & & & & & & & \\ \text { Sep. 04 } & 1545 & 15 & 30.5 & 8.6 & 395 & 73 & 0 & 9.2 & 11 & 56 \\ \text { Oct. 10 } & 1445 & 16 & 17.0 & 8.7 & 389 & 89 & 0 & 8.7 & 3 & 59 \\ \text { Nov. 07 } & 1140 & 50 & 5.0 & 7.5 & 170 & 47 & -- & 12.3 & 1 & 12 \\ \text { Dec. 12 } & 1250 & 117 & 2.5 & 6.8 & 148 & 35 & -- & 13.6 & \text { E0 } & 9.0 \\ & & & & & & & & & & \\ \text { 1974 } & & & & & & & & & & \\ \text { Jan. 09 } & 1115 & -- & 6.4 & 228 & 42 & - & 13.6 & 2 & 25 \\ \text { Feb. 14 } & 1045 & -- & .5 & 6.6 & 148 & 33 & -- & 14.0 & 6 & 12 \\ \text { Mar. 14 } & 1130 & 170 & 1.0 & 7.2 & 145 & 22 & -- & 13.5 & 10 & 11 \\ \text { Apr. 03 } & 1025 & 540 & 3.0 & 6.5 & 114 & 22 & -- & 12.5 & 32 & 4.0 \\ \text { May 02 } & 1100 & 76 & 9.0 & 8.3 & 212 & 36 & 0 & 12.4 & 1 & 23 \\ \text { June 13 } & 1130 & 12 & 17.0 & 8.5 & 267 & 71 & 0 & 11.4 & 2 & 30 \\ \text { July 18 } & 1030 & 12 & 21.0 & 8.0 & 469 & 81 & -- & 7.6 & 2 & 76 \\ \text { Aug. 15 } & 1120 & 7.6 & 20.0 & 7.8 & 572 & 110 & -- & 8.4 & 10 & 93\end{array}$

E - Estimated. 
Table 6.--Water quality results for the Tioga River basin, September 1973 to May 1975--Continued.

01518870 COWANESQUE RIVER AT COWANESQUE, PA.

\section{CHEMICAL ANALYSES}

(Milligrams per litre unless otherwise noted)

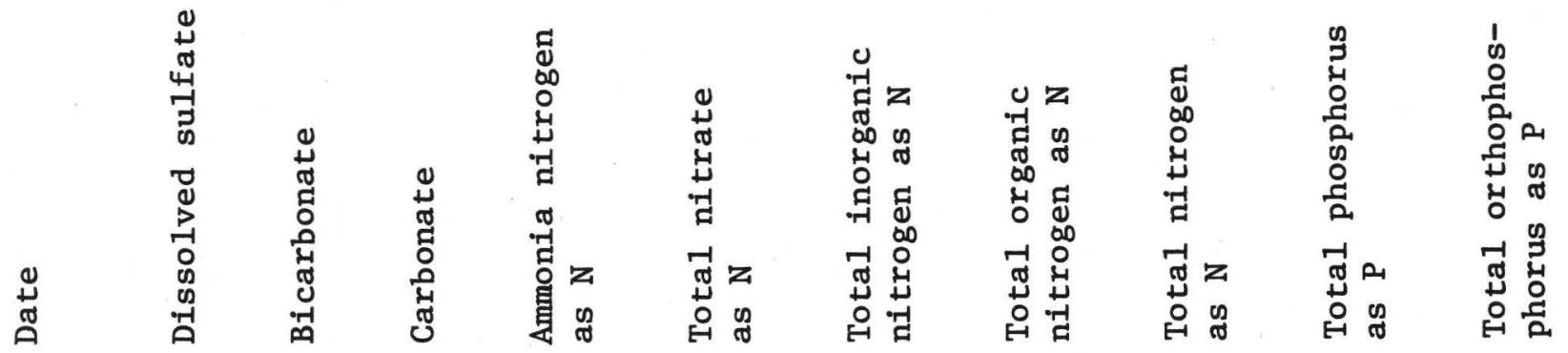

1973

\begin{tabular}{|c|c|c|c|c|c|c|c|c|c|c|}
\hline Sep. 04 & 54 & 103 & 0 & .35 & .29 & .64 & .49 & 1.1 & .14 & .08 \\
\hline Oct. 10 & 29 & 108 & 3 & .02 & .11 & .13 & .19 & .32 & .01 & .00 \\
\hline Nov. 07 & 20 & 55 & 0 & .18 & .50 & .68 & .25 & .93 & .03 & .02 \\
\hline Dec. 12 & 20 & 42 & 0 & .11 & .57 & .68 & .19 & .87 & .03 & .01 \\
\hline \multicolumn{11}{|l|}{1974} \\
\hline Jan. 09 & 26 & 49 & 0 & .52 & .80 & 1.3 & .52 & 1.8 & $\therefore 04$ & .03 \\
\hline Feb. 14 & 19 & 38 & 0 & .18 & .70 & .88 & .46 & 1.3 & .05 & .03 \\
\hline Mar. 14 & 17 & 35 & 0 & .24 & .57 & .81 & .36 & 1.2 & .05 & .03 \\
\hline Apr. 03 & 18 & 27 & 0 & .15 & 1.0 & 1.2 & .48 & 1.6 & .14 & .04 \\
\hline May 02 & 26 & 46 & 0 & .34 & .10 & .44 & .64 & 1.1 & .04 & .02 \\
\hline June 13 & 23 & 82 & 4 & .16 & .45 & .61 & .23 & .84 & .03 & .02 \\
\hline July 18 & 40 & 102 & 0 & .59 & .18 & .77 & .72 & 1.5 & .10 & .04 \\
\hline Aug. 15 & 46 & 130 & 0 & .59 & .20 & .79 & .81 & 1.6 & .12 & .07 \\
\hline
\end{tabular}


Table 6.--Water quality results for the Tioga River basin, September 1973 to May 1975--Continued.

01519000 TROUPS CREEK AT KNOXVILLE, PA.

\author{
CHEMICAL ANALYSES
}

(Milligrams per litre unless otherwise noted)

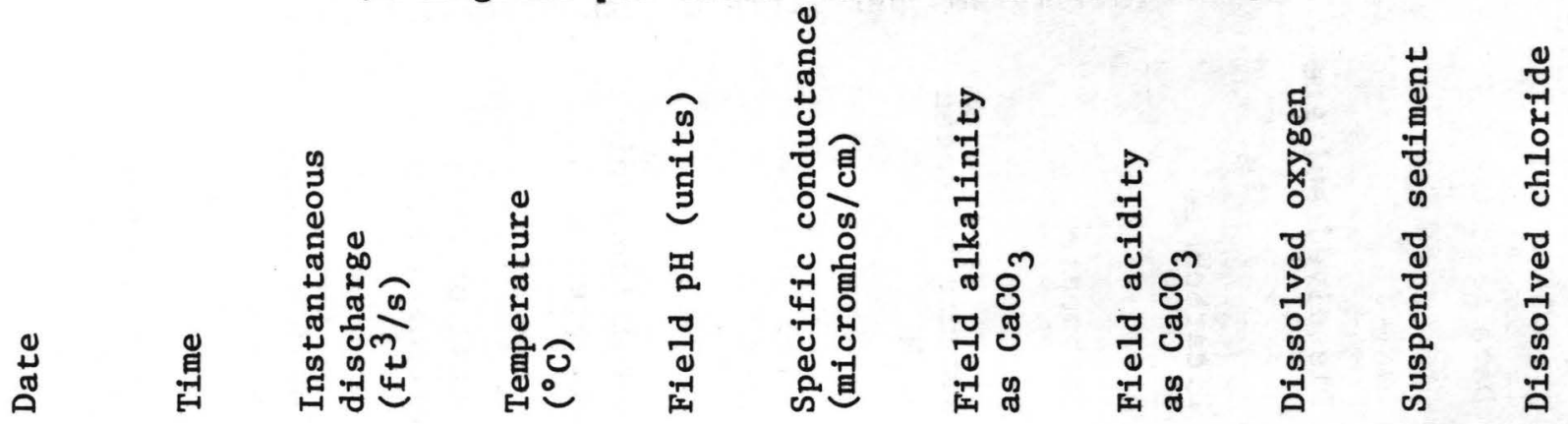

\title{
1973
}

Sep. $04 \quad 1645$

Oct. $10 \quad 1320$

Nov. $07 \quad 1310$

Dec. 130900

$\begin{array}{rr}6.5 & 30.0 \\ 5.3 & 16.0 \\ 22 & 5.0 \\ 44 & .5\end{array}$

8.8216

69

8.2239

97

$\begin{array}{lll}0 & 9.7 & 13\end{array}$

6.6

7.6222

$\begin{array}{lll}-- & 10.7 & 5 \\ -- & 12.2 & 4\end{array}$

12

7.2191

-- 14.3 EO

8.0

1974

Jan. $09 \quad 1025$

$\begin{array}{rr}-- & .0 \\ -- & .5 \\ 109 & 3.5 \\ 312 & 4.5 \\ 39 & 13.0 \\ 5.6 & 21.0 \\ 3.7 & 22.0 \\ 2.6 & 24.0\end{array}$

6.5194

52

-- $14.4 \quad 36.5$

Feb. $14 \quad 1125$

6.2140

40

- $\quad 14.215$

7.5

Mar. $14 \quad 1745$

$7.4 \quad 140$

-- $\quad 12.8 \quad 69$

5.0

Apr. $03 \quad 1145$

6.1124

32

$--\quad 12.5 \quad 63$

4.0

May $02 \quad 1230$

June $13 \quad 1230$

8.6169

55

8.0213

0

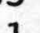

5.2

July $18 \quad 1100$

8.7232

86

$\begin{array}{llll}0 & -- & 1 & 7.5\end{array}$

Aug. $15 \quad 1240$

$8.5 \quad 219$

85

84

$0 \quad 10.0$

$\begin{array}{ll}1 & 7.5 \\ 0 & 7.6\end{array}$

$\begin{array}{llll}0 & 10.6 & 4 & 9.0\end{array}$

E - Estimated. 
Table 6.--Water quality results for the Tioga River basin, September 1973 to May 1975--Continued.

01519000 TROUPS CREEK AT KNOXVILLE, PA.

\author{
CHEMICAL ANALYSES
}

(Milligrams per litre unless otherwise noted)

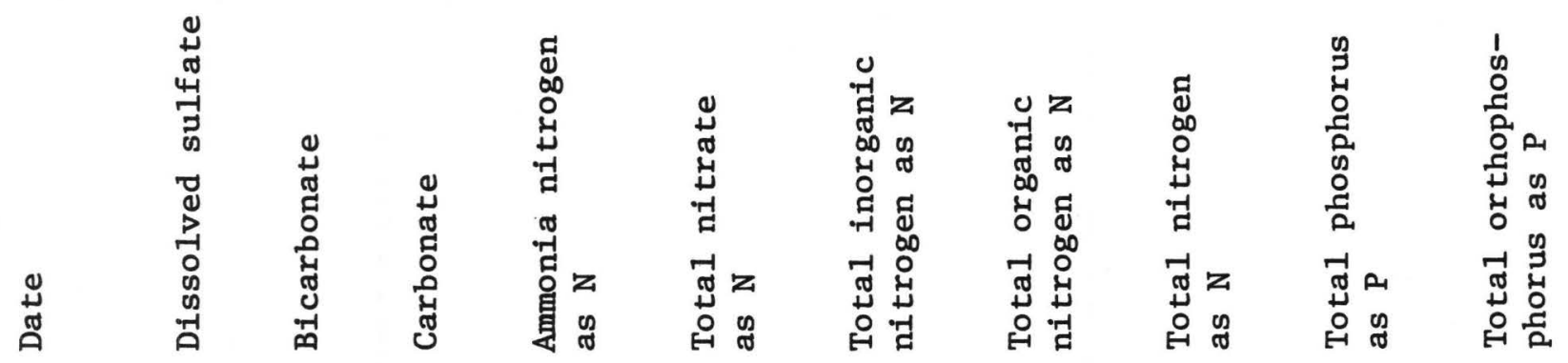

1973

$\begin{array}{lrrrrcccccc}\text { Sep. } 04 & 30 & 93 & 2 & .05 & .20 & .25 & .61 & .86 & .01 & .01 \\ \text { Oct. 10 } & 22 & 116 & 1 & .02 & .66 & .68 & .32 & 1.0 & .01 & .01 \\ \text { Nov. 07 } & 27 & 90 & 0 & .09 & 1.2 & 1.3 & .68 & 2.0 & .01 & .00 \\ \text { Dec. 13 } & 26 & 65 & 0 & .04 & .90 & .94 & .19 & 1.1 & .02 & .00 \\ & & & & & & & & & & \\ 1974 & & & & & & & & & \\ \text { Jan. 09 } & 26 & 63 & 0 & .10 & 1.8 & 1.9 & .22 & 2.1 & .02 & .02 \\ \text { Feb. 14 } & 20 & 49 & 0 & .02 & .90 & .92 & .42 & 1.3 & .07 & .02 \\ \text { Mar. 14 } & 16 & 44 & 0 & .06 & 1.4 & 1.5 & .33 & 1.8 & .11 & .04 \\ \text { Apr. 03 } & 20 & 32 & 0 & .14 & 1.7 & 1.8 & .54 & 2.4 & .11 & .05 \\ \text { May 02 } & 23 & 66 & 4 & .08 & .20 & .28 & .26 & .54 & .02 & .00 \\ \text { June 13 } & 20 & 92 & 5 & .06 & .50 & .56 & .21 & .77 & .01 & .00 \\ \text { Ju1y 18 } & 19 & 102 & 2 & .06 & .34 & .40 & .28 & .68 & .01 & .00 \\ \text { Aug. 15 } & 20 & 88 & 5 & .07 & .23 & .30 & .19 & .49 & .01 & .00\end{array}$


Table 6.--Water quality results for the Tioga River basin, September 1973 to May 1975--Continued.

01519500 COWANESQUE RIVER AT NELSON, PA.

CHEMICAL ANALYSES

(Milligrams per litre unless otherwise noted)
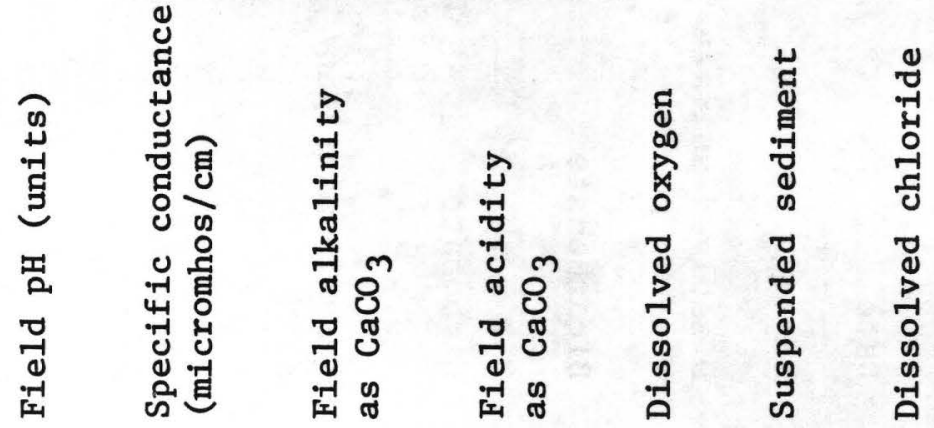

1973

Sep. 05

Oct. 10
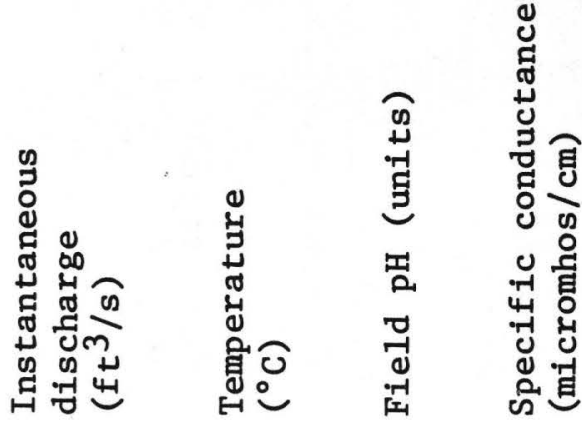

$8.0 \quad 264$

$7.4 \quad 327$

$7.8 \quad 220$

$7.2 \quad 179$

2.0

.0

.5

4.0

7.0

15.0

22.5

27.5

26.0
$6.8 \quad 224$

6.9166

7.2171

$6.4 \quad 133$

8.9195

8.5276

$9.3 \quad 310$

8.7364
69

82

62

49

\section{5}

42

39

28

51

82

79

81 $\begin{array}{rrrr}-- & 10.8 & 55 & 20 \\ -- & 9.6 & 2 & 32 \\ -- & 12.6 & 2 & 16 \\ -- & 13.6 & \text { EO } & 16\end{array}$

$\begin{array}{llll}- & 15.2 \quad 2 & 13\end{array}$

$\begin{array}{llll}- & 14.1 & 15 & 12\end{array}$

$\begin{array}{llll}- & 13.2 & 11 & 11\end{array}$

$\begin{array}{llll}-- & 12.4 & 31 & 5.5\end{array}$

$\begin{array}{llll}0 & 11.4 & 1 & 13\end{array}$

$\begin{array}{llll}0 & -- & 6 & 24\end{array}$

$\begin{array}{llll}0 & 11.4 & 1 & 34\end{array}$

$\begin{array}{llll}0 & 10.8 & 8 & 47\end{array}$

E - Estimated. 
Table 6.--Water quality results for the Tioga River basin, September 1973 to May 1975--Continued.

01519500 COWANESQUE RIVER AT NELSON, PA.

CHEMICAL ANALYSES

(Milligrams per litre unless otherwise noted)

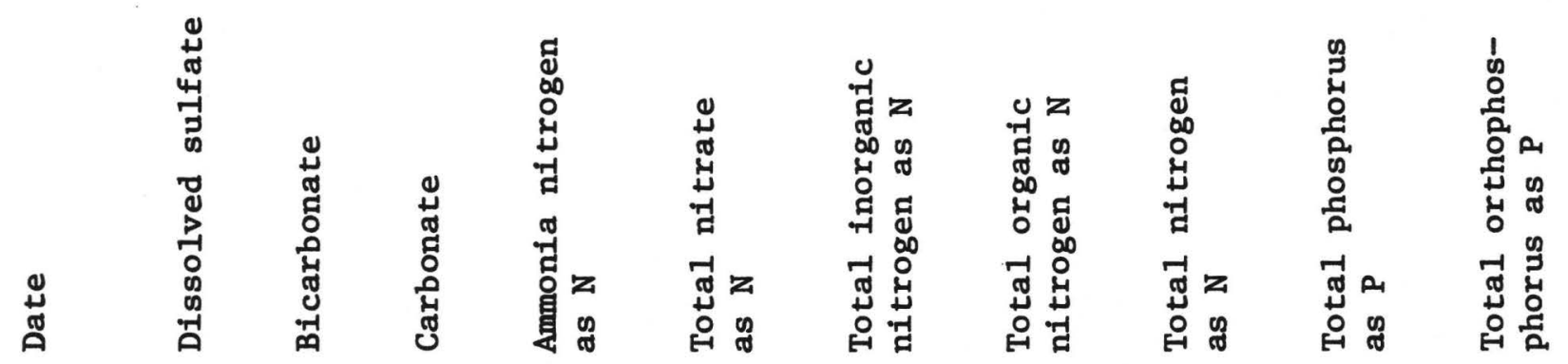

1973

Sep. 05

0ct. 10

Nov. 07

Dec. 12

$\begin{array}{lll}25 & 100 & 0\end{array}$

.20

.61

$.31 \quad .14$

$.09 \quad .59$

$.03 \quad .61$

$.81 \quad .63$

$.45 \quad .50$

$.68 \quad .35$

$.64 \quad .20$

$\begin{array}{ccc}1.4 & .12 & .08 \\ .95 & .08 & .04 \\ 1.0 & .05 & .03 \\ .84 & .06 & .04\end{array}$

1974

Jan. 09

Feb. 14

$\begin{array}{lll}27 & 64 & 0\end{array}$

.17

.14

1.9

2.1

.35

.80

.94

.48

2.4

$\begin{array}{lll}.99 & 1.1 & .32\end{array}$

.12

1.3

1.4

.48

1.4

1.4

1.9

.52

.05

.04

Apr. 03

$19 \quad 34$

.09

.10

$.19 \quad .33$

1.2

.36

$.67 \quad .56$

.08

$\begin{array}{lll}.02 & .10 & .34 \\ .14 & .33 & .47\end{array}$

.19

$\begin{array}{lll}.02 & .10 & .34 \\ .14 & .33 & .47\end{array}$

.44

.80

.06

.04

.03

.05

.01

.10

.03

.02

$\begin{array}{llr}38 & 90 & 5\end{array}$

.14

.01

.02 
Table 6.--Water quality results for the Tioga River basin, September 1973 to May 1975--Continued.

01520000 COWANESQUE RIVER NEAR LAWRENCEVILLE, PA.

CHEMICAL ANALYSES

(Milligrams per litre unless otherwise noted)

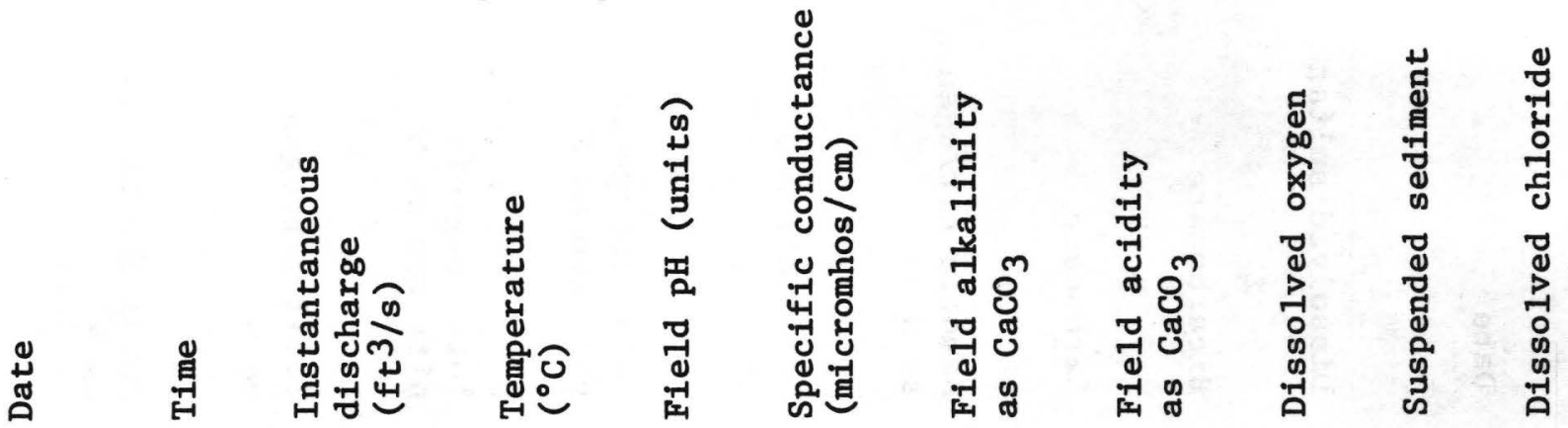

1973

\begin{tabular}{|c|c|c|c|c|c|c|c|c|c|c|}
\hline Sep. 05 & 1340 & 70 & 27.0 & 8.1 & 241 & 59 & -- & 11.2 & 51 & 19 \\
\hline Oct. 09 & 1740 & 63 & 18.0 & 9.0 & 309 & 89 & 0 & 10.6 & E0 & 35 \\
\hline Nov. 06 & 1510 & 148 & 5.0 & 7.8 & 223 & 62 & -- & 12.1 & 9 & 17 \\
\hline Dec. 12 & 1510 & 287 & 2.5 & 6.8 & 176 & 45 & -- & 13.6 & EO & 16 \\
\hline \multicolumn{11}{|l|}{1974} \\
\hline Jan. 08 & 1545 & E170 & .0 & 6.4 & 205 & 48 & -- & 14.2 & 5 & 14 \\
\hline Feb. 14 & 1430 & E170 & .5 & 6.9 & 164 & 41 & -- & 14.4 & EO & 12 \\
\hline Mar. 14 & 1450 & 317 & 3.5 & 7.3 & 158 & 35 & -- & 13.9 & 22 & 9.2 \\
\hline Apr. 03 & 1625 & 1400 & 6.5 & 6.3 & 124 & 24 & -- & 12.2 & 52 & 5.0 \\
\hline May 02 & 1530 & 215 & 15.5 & 9.1 & 189 & 52 & 0 & 13.2 & 2 & 12 \\
\hline June 13 & 1535 & E42 & 24.0 & 8.7 & 274 & 84 & 0 & -- & 2 & 24 \\
\hline July 18 & 1340 & 29 & 27.0 & 8.8 & 300 & 78 & 0 & 9.2 & 2 & 29 \\
\hline Aug. 15 & 1500 & 17 & 28.0 & 8.5 & 337 & 83 & 0 & 9.2 & 5 & 38 \\
\hline Sep. 13 & 0930 & 30 & 21.0 & 7.8 & 347 & 83 & - & 9.0 & EO & 39 \\
\hline 0ct. 11 & 1010 & 31 & 9.0 & 7.9 & 352 & 90 & 2 & 11.4 & EO & 37 \\
\hline Nov. 07 & 1430 & 215 & 8.0 & 7.2 & 212 & 54 & 6 & 14.4 & 4 & 15 \\
\hline Dec. 10 & 0930 & 573 & .0 & 7.6 & 148 & 52 & 4 & 13.8 & 8 & 8.0 \\
\hline \multicolumn{11}{|l|}{1975} \\
\hline Jan. 15 & 0930 & 417 & .0 & 7.1 & 157 & 33 & 1 & - & 3 & 9.0 \\
\hline Feb. 04 & 0945 & E180 & .0 & 7.7 & 163 & 39 & 4 & 14.4 & EO & 10 \\
\hline Mar. 06 & 0840 & E280 & 1.0 & 7.4 & 164 & 39 & 2 & 12.8 & 4 & 10 \\
\hline Apr. 02 & 0900 & 304 & 3.5 & 7.8 & 144 & 37 & 2 & 12.0 & 5 & 9.5 \\
\hline May 15 & 0900 & 261 & 14.0 & 8.3 & 164 & 45 & 0 & 10.2 & 6 & 7.5 \\
\hline
\end{tabular}

E - Estimated. 
Table 6.--Water quality results for the Tioga River basin, September 1973 to May 1975--Continued.

01520000 COWANESQUE RIVER NEAR LAWRENCEVILLE, PA.

CHEMICAL ANALYSES

(Milligrams per litre unless otherwise noted)
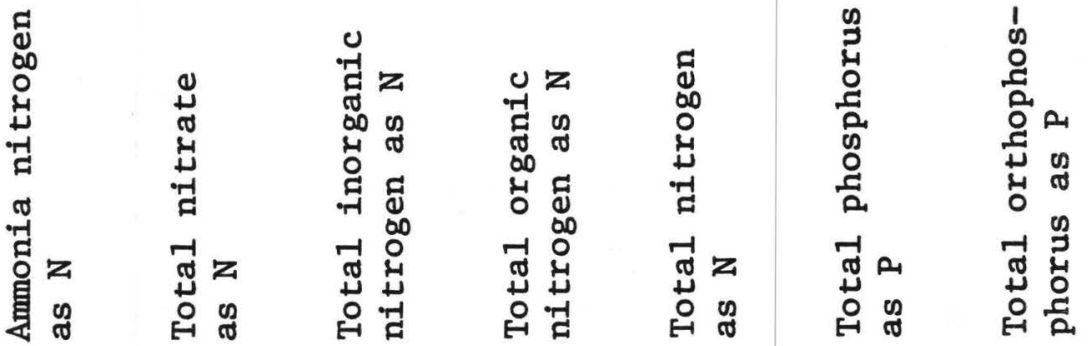

1973

Sep. 05

Oct. 09

23

87

.27

.45

$.01 \quad .05$

.72

.56

$.06 \quad .16$

.12

.66

.29

Dec. 12

25

77

.54

$.66 \quad .18$

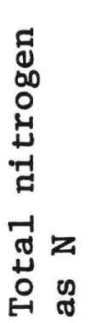

$.03 \quad .63$

1.

.22

.02

.10

.95

.04

.02

.84

.06

.04

\section{4}

Jan. 08

Feb. 14

$26 \quad 59 \quad 0$

.13

1.0

1.1

.38

$\begin{array}{llll}.08 & .80 & .88 & .36\end{array}$

.10

.84

.94

.28

.12

1.0

1.1

.47

.08

.10

.18

.27

.13

.27

.40

.31

.06

.07

.13

.27

$\begin{array}{llll}.09 & .09 & .18 & .30\end{array}$

.08

.09

.17

.24

$.10 \quad .22$

.05

.05

.34

.35

$.90 \quad .41$

1.5

1.2

1.2

1.6

.45

.71

.40

.48

.41

.32

.69

.09

.81

1.3

.04

.08

.04

.04

.10

.02

.03

.05

Dec. 10

$25 \quad 48$

0

41

.02

.01

.02

.01

.03

.01

.02

.01

.01

.01

.04

.00

.04

.03

\section{5}

Jan. 15

Feb. 04

$26 \quad 42 \quad 0$

$.07 \quad 1.0$

1.1

.55

.95

1.0

.49

1.6

.06

1.5

.0

.08

1.2

1.2

.36

1.6

.04

1.1

.04

.17

.02

$\begin{array}{lll}.77 & .77 & .30 \\ .09 & .10 & .17\end{array}$

.02

.02

.00

.09

.10

.01 
Table 6.--Water quality results for the Tioga River basin,

September 1973 to May 1975--Continued.

01520500 TIOGA RIVER AT LINDLEY, N.Y.

CHEMICAL ANALYSES

(Milligrams per litre unless otherwise noted)

1973

\begin{tabular}{|c|c|c|c|c|c|c|c|c|c|c|}
\hline Sep. 05 & 1445 & 178 & 27.5 & 7.5 & 256 & 41 & -- & 10.0 & 5 & 14 \\
\hline Oct. 09 & 1825 & 182 & 17.0 & 6.8 & 268 & 41 & -- & 10.2 & 3 & 16 \\
\hline Nov. 06 & 1600 & 405 & 5.0 & 7.0 & 182 & 31 & -- & 11.6 & 10 & 8.5 \\
\hline Dec. 11 & 1550 & 1630 & 2.5 & 6.7 & 148 & 24 & -- & 12.7 & 39 & 6.8 \\
\hline \multicolumn{11}{|l|}{1974} \\
\hline Jan. 08 & 1450 & 440 & .0 & 6.2 & 200 & 27 & -- & 13.8 & 10 & 15 \\
\hline Feb. 14 & 1530 & E500 & .5 & 6.7 & 153 & 28 & -- & 14.0 & EO & 10 \\
\hline Mar. 14 & 1400 & E1160 & 2.0 & 6.7 & 143 & 18 & -- & 13.4 & 22 & 5.4 \\
\hline Apr. 03 & 1710 & 3280 & 6.5 & 6.2 & 118 & 20 & -- & 12.2 & 35 & 4.0 \\
\hline May 02 & 1430 & 604 & 14.0 & 7.4 & 172 & 33 & 3 & 10.7 & 10 & 7.4 \\
\hline June 13 & 1430 & 172 & 20.0 & 7.2 & 216 & 40 & - & - & 4 & 10 \\
\hline July 18 & 1245 & 119 & 24.0 & 7.2 & 269 & 47 & 6 & 9.0 & 1 & 12 \\
\hline Aug. 15 & 1355 & 63 & 25.0 & 7.4 & 328 & 34 & -- & 9.2 & 5 & 17 \\
\hline Sep. 13 & 1500 & 83 & 24.0 & 7.4 & 342 & 36 & -- & 8.4 & EO & 20 \\
\hline Oct. 11 & 1115 & 90 & 11.0 & 7.5 & 329 & 36 & 3 & 10.6 & E0 & 18 \\
\hline Nov. 07 & 1530 & 478 & 8.5 & 7.0 & 203 & 43 & 6 & 12.8 & 9 & 11 \\
\hline Dec. 10 & 1015 & 2040 & .5 & 7.1 & 125 & 31 & 4 & 14.8 & 29 & 5.5 \\
\hline \multicolumn{11}{|l|}{1975} \\
\hline Jan. 15 & 1030 & 1020 & .0 & 7.0 & 157 & 20 & 2 & -- & 10 & 6.5 \\
\hline Feb. 04 & 1015 & 722 & .0 & 7.4 & 176 & 24 & 5 & 14.0 & EO & 8.0 \\
\hline Mar. 06 & 0930 & 722 & .5 & 6.6 & 177 & 22 & 7 & 12.7 & 18 & 8.0 \\
\hline Apr. 02 & 0950 & 728 & 4.5 & 7.2 & 142 & 23 & 7 & 11.6 & 15 & 7.0 \\
\hline May 15 & 1000 & 755 & 14.5 & 7.7 & 151 & 31 & 2 & 8.8 & 13 & 5.5 \\
\hline
\end{tabular}

E - Estimated. 
Table 6.--Water quality results for the Tioga River basin,

September 1973 to May 1975--Continued.

01520500 TIOGA RIVER AT LINDLEY, N.Y.

CHEMICAL ANALYSES

(Milligrams per litre unless otherwise noted)

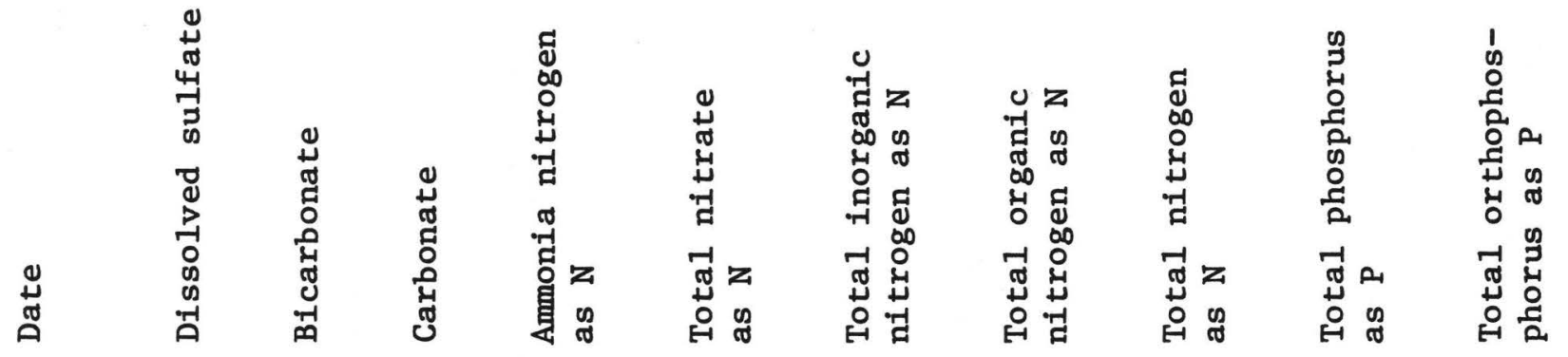

1973

$\begin{array}{ccccccccccc}\text { Sep. 05 } & 23 & 61 & 0 & .21 & .50 & .71 & .23 & .94 & .09 & .06 \\ \text { Oct. 09 } & 61 & 48 & 0 & .04 & .08 & .12 & .16 & .28 & .03 & .02 \\ \text { Nov. 06 } & 49 & 38 & 0 & .16 & .34 & .50 & .25 & .15 & .05 & .02 \\ \text { Dec. 11 } & 35 & 24 & 0 & .04 & .66 & .70 & .23 & .93 & .07 & .05 \\ \text { 1974 } & & & & & & & & & & \\ \text { Jan. 08 } & 46 & 32 & 0 & .13 & 1.0 & 1.1 & .21 & 1.3 & .03 & .01 \\ \text { Feb. 14 } & 31 & 35 & 0 & .20 & .70 & .90 & .35 & 1.2 & .05 & .03 \\ \text { Mar. 14 } & 28 & 24 & 0 & .09 & .77 & .86 & .18 & 1.0 & .02 & .02 \\ \text { Apr. 03 } & 23 & 24 & 0 & .16 & .70 & .86 & .45 & 1.3 & .10 & .03 \\ \text { May 02 } & 39 & 38 & 0 & .08 & .20 & .28 & .20 & .48 & .03 & .01 \\ \text { June 13 } & 56 & 44 & 0 & .13 & .36 & .49 & .22 & .71 & .02 & .01 \\ \text { Ju1y 18 } & 73 & 36 & 0 & .07 & .09 & .16 & .15 & .31 & .01 & .00 \\ \text { Aug. 15 } & 92 & 42 & 0 & .16 & .16 & .32 & .22 & .54 & .02 & .00 \\ \text { Sep. 13 } & 84 & 44 & 0 & .09 & .18 & .27 & .16 & .43 & .01 & .00 \\ \text { Oct. 11 } & 93 & 44 & 0 & .10 & .18 & .28 & .18 & .46 & .01 & .00 \\ \text { Nov. 07 } & 41 & 52 & 0 & .01 & .32 & .33 & .32 & .65 & .04 & .02 \\ \text { Dec. 10 } & 31 & 18 & 0 & .09 & .70 & .79 & .33 & 1.1 & .07 & .05 \\ \text { 1975 } & & & & & & & & & & \\ \text { Jan. 15 } & 44 & 22 & 0 & .07 & .86 & .93 & .30 & 1.2 & .03 & .03 \\ \text { Feb. 04 } & 49 & 28 & 0 & .05 & .86 & .91 & .29 & 1.2 & .02 & .02 \\ \text { Mar. 06 } & 48 & 26 & 0 & .03 & 1.2 & 1.2 & .25 & 1.5 & .03 & .02 \\ \text { Apr. 02 } & 39 & 29 & 0 & .01 & .72 & .73 & .23 & .96 & .03 & .02 \\ \text { May 15 } & 32 & 35 & 0 & .01 & .23 & .25 & .12 & .37 & .03 & .01\end{array}$


Table 6.--Water quality results for the Tioga River basin, September 1973 to May 1975--Continued.

01520500 TIOGA RIVER AT LINDLEY, N.Y.

\author{
CHEMICAL ANALYSES \\ (Micrograms per litre)
}

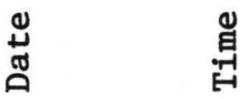

热

貝

㫕

\title{
Dissolved
}

1974

Feb. 14

Mar. 14

1530

1400

Apr. 03

1710

1975

Mar. 06

0930

0950

1000

30

20

May 15

50

0

1

1

0
0
0

0

0

10

13

10

10

0

Tota1

\section{4}

May 02

June 13

July 18

Aug. 15

Sep. 13

Oct. 11

Nov. 07

Dec. 10

1975

Jan. 15

Feb. 04
1430

1430

1245

1355

1500

1115

1530

1015

1030

1015
700

0

280

80

80

230

540

920

670

470 
Table 6.--Water quality results for the Tioga River basin, September 1973 to May 1975--Continued.

01520500 TIOGA RIVER AT LINDLEY, N.Y.

CHEMICAL ANALYSES

(Micrograms per litre)

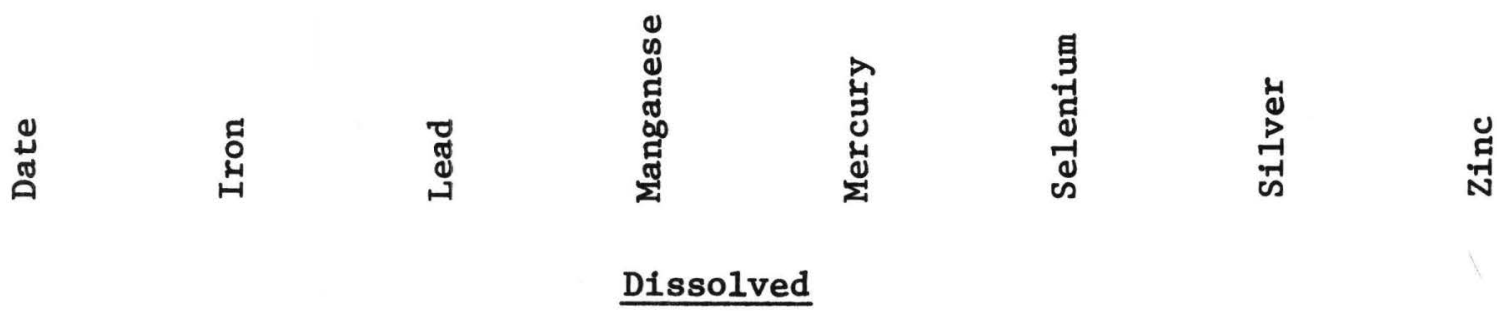

1974

Feb. 14

Mar. 14

Apr. 03

20

50

80

1975

Mar. 06

310

Apr. 02

May 15

180

70

2790

590

390

$<.5$

$<.5$

$<.5$

$\overline{--}$

$-$

$-$

$--$

--

1

0

90

60

40

Tota1

1974

May 02

June 13

July 18

Aug. 15

Sep. 13

Oct. 11

Nov. 07

Dec. 10

490

180

0

70

150

160

650

1200

\section{4}

1

1

0

0

2

0

1

0

0

0

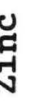

\section{5}

Jan. 15

900

930

2
3

660

850

0

$<1$

$<1$

0

2

2

0

0

360

$<.5$

$<.5$

$<.5$

$<.5$
0

0
130

60

310

100

200

290

80

50

50

110 